Life Sciences Contributions
Royal Ontario Museum

The Ammonoid Fauna of the

Kimmeridgian-Tithonian

Boundary Beds of Mombasa, Kenya

Harish M. Verma

G. E. G. Westermann

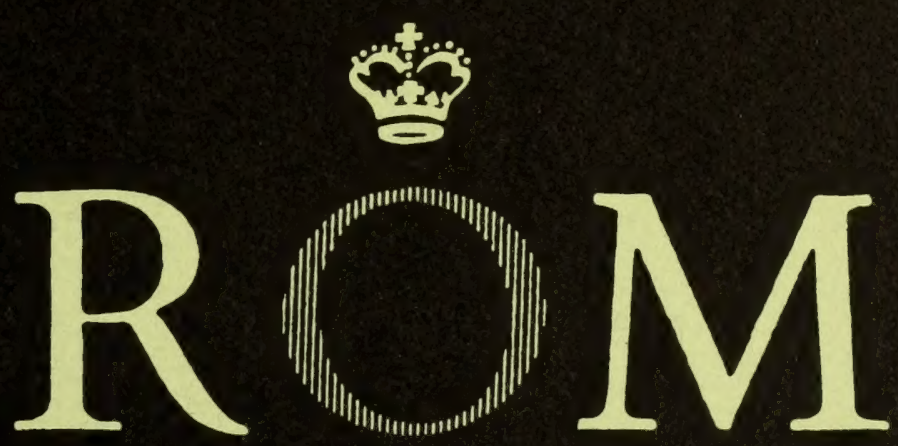




\section{ROYAL ONTARIO MUSEUM LIFE SCIENCES PUBLICATIONS INSTRUCTIONS TO AUTHORS}

Authors are to prepare their manuscripts carefully according to the following instructions. Failure to do so will result in the manuscript's being returned to the author for revision. All manuscripts are considered on the understanding that if accepted they will not be offered for publication elsewhere.

1. GENERAL Papers for publication are accepted from ROM staff members, Research Associates, or from researchers reporting on work done with ROM collections. In exceptional cases,monographic works on the flora and/or fauna of Ontario will be considered for publication by authors not affiliated with the ROM. Authors are expected to write clearly and concisely, and to omit all material not essential for an understanding of the main theme of the paper.

2. FORMAT Manuscripts are to be typed double-spaced (including captions, synonomies, literature cited, and tables)

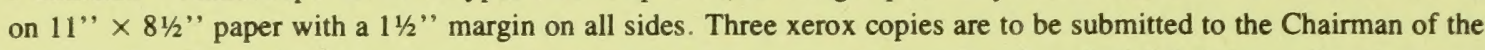
Editorial Board, and the original retained by the author(s). A separate sheet is to be submitted giving author(s) names, affiliation, title of publication, series in which it is to appear, number of typed pages, number of tables, and number of figures. Manuscripts should normally be organized in the following order: Table of Contents, Abstract, Introduction, Materials and Methods, Results, Discussion, Conclusions, Summary (if paper is long), Acknowledgements, Literature Cited, and Appendices. Authors are encouraged to include foreign language translations of the Summary where appropriate. Headings of sections are to be left-justified to the text margin. The first line of the first paragraph in each new section should not be indented. Text-figures are referred to as "Fig. 1". Literature cited in the text is in the form "Jones (1972)" or "(Jones, 1972)" or "(Smith, 1960:71-79, fig. 17)"

3. STANDARD SOURCES The primary source for decisions on format and style is A Guide for Contributors and Editors of ROM Life Sciences Publications, available from the Chairman of the Editorial Board. Otherwise, consult CBE (AIBS) Style Manual (3rd Edition). Other standard sources are as follows: for English spelling (Concise Oxford Dictionary), for Canadian place names and coordinates (Gazetteer of Canada), and for spelling of geographic names (Times [London] Atlas).

4. ABSTRACT All papers are preceded by a short and factual abstract, about 3 per cent as long as the text, but not longer than 400 words. The abstract is to be followed by four to six keywords enclosed in brackets.

5. TAXONOMY The name of a taxon is given in full in headings, where it appears for the first time, or when the name begins a paragraph. Use authority and date if appropriate, with first mention of each taxon and not thereafter. Taxonomic papers follow the layout in Life Sciences Contribution 99, particularly the synonomies.

6. LITERATURE CITED References in the text cite author and date and are enclosed in parentheses (Smith, 1978). Complete references are listed in alphabetical order by author at the end of the paper. When there are two or more citations for an author, the works are listed chronologically. Names of journals are not abbreviated. Consult Life Sciences Contributions beginning with 117 for correct bibliographic form.

7. TABLES All tables are numbered consecutively in arabic numerals in numerical order of their first mention in the text. Mark the appropriate text location of each table with a marginal notation. Each table is typed on a separate sheet. Avoid footnotes etc., to tables by building them into the title.

8. FIGURES All figures are numbered consecutively in arabic numerals. Component photographs or drawings are labelled sequentially in upper case letters. Mark the appropriate text location of each figure with a marginal notation. The intended reduction for figures is ideally one and a half to two times. All labelling on figures is in blue pencil and not inked or letraset. Halftones must be photographic prints of high contrast on glossy paper. Authors are to submit 10 " $\times 8$ " copies with the MS and retain originals until they are requested. Figure captions are to appear grouped together on a separate page at the end of the MS. 
LIFE SCIENCES CONTRIBUTIONS

ROYAL ONTARIO MUSEUM

NUMBER 135

HARISH M. VERMA

G. E. G. WESTERMANN

\author{
The Ammonoid Fauna of the \\ Kimmeridgian-Tithonian \\ Boundary Beds \\ of Mombasa, Kenya
}




\section{ROYAL ONTARIO MUSEUM PUBLICATIONS IN LIFE SCIENCES}

The Royal Ontario Museum publishes three series in the Life Sciences:

LIFE SCIENCES CONTRIBUTIONS, a numbered series of original scientific publications including monographic works.

LIFE SCIENCES OCCASIONAL PAPERS, a numbered series of original scientific publications, primarily short and usually of taxonomic significance.

LIFE SCIENCES MISCELLANEOUS PUBLICATIONS, an unnumbered series of publications of varied subject matter and format.

All manuscripts considered for publication are subject to the scrutiny and editorial policies of the Life Sciences Editorial Board, and to review by persons outside the Museum staff who are authorities in the particular field involved.

\section{LIFE SCIENCES EDITORIAL BOARD}

Senior Editor: J. R. TAMSITT

Editor: DALE R. CALDER

Editor: JON BARLOW

External Editor: C. S. CHLRCHER

Manuscript Editor: RICHARD WINTERBOTTOM

Production Editor: ANDREA GALLAGHER ELLIS

HARISH M. VERMA is a Research Associate of the Department of Invertebrate Palaeontology, Royal Ontario Museum.

G. E. G. Westermann is Professor in the Department of Geology, McMaster University, Hamilton, Ontario, and a Research Associate of the Department of Invertebrate Palaeontology, Royal Ontario Museum.

\section{Canadian Cataloguing in Publication Data}

Verma, Harish, M.

Ammonoid fauna of the Kimmeridgian-Tithonian

boundary beds of Mombasa, Kenya

(Life sciences contributions, ISSN 0384-8159; no. 135)

Bibliography: p. 116

ISBN 0-88854-297-6

1. Ammonoidea. 2. Paleontology - Jurassic.

3. Paleontology - Kenya - Frere Town. I. Westermann,

G. E. G. (Gerd Ernst Gerold), 1927- II. Royal

Ontario Museum. III. Title. IV. Series.

QE807.A5V47 564'.53'0967623 C83-098584-0

Publication Date: 28 March 1984

ISBN 0-88854-297-6

ISSN 0384-8159

(C) The Royal Ontario Museum, 1984

100 Queen's Park, Toronto, Canada M5S 2C6

PRINTED AND BOLND IN CANADA AT THE ALGER PRESS 


\section{Contents}

Abstract 1

Introduction 2

Materials and Methods 4

Previous Work on Upper Jurassic of Mombasa Area 4

Upper Jurassic in Vicinity of Freretown 9

Previous Work 9

New Work 13

Age and Affinity of Freretown Ammonoid Fauna 17

Introduction to Kimmeridgian and Tithonian Stages 17

Age of Freretown Fauna 18

Upper Assemblage 19

Lower Assemblage 22

Ecology and Biogeography of Freretown Ammonoid Fauna 23

Introduction 23

Ecology 24

Biogeography 25

Systematics 27

Suborder Phylloceratina Arkell, 195027

Family Phylloceratidae Zittel, 188427

Subfamily Phylloceratinae Zittel, 188427

Phylloceras isotypum Benecke, 186527

Subfamily Calliphylloceratinae Spath, 192728

Calliphylloceras benacense (Catullo, 1847) 28

C. aff. C. malayanum (Boehm, 1907) 29

Ptychophylloceras ptychoicum (Quenstedt, 1845) 29

Holcophylloceras polyolcum mesolcum (Dietrich, 1925) 31

Suborder Lytoceratina Hyatt, 188932

Family Lytoceratidae Neumayr, 187532

Subfamily Lytoceratinae Neumayr, 187532

Lytoceras fraasi Dacqué, 191032

Pterolytoceras montanum (Oppel, 1865) 33

Suborder Ammonitina Hyatt, 188934

Superfamily Haplocerataceae Zittel, 188434

Family Oppeliidae Douvillé, 189034

Subfamily Taramelliceratinae Spath, 192834

Taramelliceras (T.) cf. T. kachhense (Waagen, 1875) 34

$T$. (T.) trachynotum (Oppel, 1862)? 35

Subfamily Streblitinae Spath, 192536

Streblites habyensis Spath, 192836

Superfamily Perisphinctaceae Steinmann, 189037

Family Perisphinctidae Steinmann, 189037

Subfamily Perisphinctinae Steinmann, 189037

Pachysphinctes beyrichi (Futterer, 1894) 39

Katroliceras pottingeri (Sowerby, 1840) 42

$K$. aff. $K$. pottingeri $i$ 43

K.? cf. K. bathyplocus (Waagen, 1875) ठิ 44 
Subdichotomoceras(?) cf. S. sparsiplicatum (Waagen, 1875) 46 S.? aff. S. sparsiplicatum (Waagen, 1875) 47

Family Ataxioceratidae Buckman, 192148

Lithacoceras cf. L. fraasi (Dacqué, 1910) 48

L.? mombassanum (Dacqué, 1910) 49

L. cf. L. albulum (Quenstedt, 1887) 49

Phanerostephanus (Nothostephanus) digoi sp. nov. ㅇ 53

Family Aulacostephanidae Spath, 192457

Procraspedites cf. $P$. africanus (Zwierzicky, 1914)우 58

Gravesia loupekinei sp. nov. ㅇ 59

G. aff. G. loupekinei sp. nov. ㅇ 63

Family Aspidoceratidae Zittel, 189563

Subfamily Aspidoceratinae Zittel, 189563

Aspidoceras cf. A. acanthicum (Oppel, 1863) + + ? $\widehat{0} 63$

A. aff. A. acanthicum (Oppel, 1863) 66

A. iphiceroides Waagen, $1875 q+\hat{o} 66$

A. cf. A. iphicerum (Oppel, 1863) 68

A. cf. A. apenninicum Zittel, (1869) $1870 \quad 69$

A. (Physodoceras) cf. A. avellanum Zittel, $1870 \quad 70$

A. (P.) circumspinosum (Quenstedt, 1858) 71

Family Simoceratidae Spath, 192472

Hybonoticeras hybonotum (Oppel, 1863) 72

$H$. cf. H. hybonotum (Oppel, 1863) 73

H. cf. H. ornatum (Spath, 1931) 73

H. pressulum (Neumayr, 1873) 75

H. cf. H. ciliatum Berckhemer \& Hölder, 195976

Acknowledgements 77

Plates 78

Literature Cited 116 


\title{
The Ammonoid Fauna of the Kimmeridgian-Tithonian \\ Boundary Beds of Mombasa, Kenya
}

\begin{abstract}
The macroinvertebrate fauna of the poorly to moderately exposed upper Changamwe Shales at Freretown, north of Mombasa, was collected with the best precision possible. The sequence consists of 370 to $600 \mathrm{~m}$ of silty shales with layers of calcareous concretions and lenticular siltstone. These have yielded a rich, almost exclusively ammonoid fauna in parts of the upper half of the section and a scarce to moderately rich similar fauna through the remainder of the section. This collection of 325 specimens was placed in 28 species, 2 of them new.

The rich and diverse upper assemblage consists of species of Phylloceratina (c. 20\%) Phylloceras, Calliphylloceras, Ptychophylloceras, Holcophylloceras, Lytoceratina (c. 5\%) Lytoceras, Pterolytoceras; and Ammonitina (c. 75\%) Taramelliceras, Streblites, Katroliceras, Pachysphinctes, Subdichotomoceras?, Lithacoceras, Aspidoceras (s. str.), A. (Physodoceras), and significantly the first findings in Africa of the genera Procraspedites, Phanerostephanus with $P$. (Nothostephanus) digoi sp. nov., Gravesia with G. loupekinei sp. nov., and of the species Hybonoticeras hybonotum. The association of Gravesia and $H$. hybonotum clearly identifies this assemblage as belonging to the Hybonotum Standard Zone ("Gravesia Zone') of the basal Tithonian, hitherto restricted to the Mediterranean Province (Tethyan Realm). This is the first good evidence of both zonal indices and thus of the Hybonotum Zone for the Indo-Southwest Pacific Province; it clearly dates the coeval Madagascan "Zone of $H$. hybonotum and Aspidoceras acanthicum" and the "2nd Katrol Assemblage" of Kachchh, India. Significantly, this "Coroa Mombasa assemblage" was previously dated at latest Kimmeridgian (s. str.), about Beckeri Zone. Faunistic comparison of this assemblage within the Ethiopian Subprovince, Indo-Southwest Pacific Province, indicates a somewhat closer affinity to Madagascar than to Kachchh, and a closer connection than previously assumed of (only) the East African-Madagascan faunas with the Mediterranean Province, in particular, the Submediterranean Subprovince of Northwest Europe. Gravesia is well known from as far north as the Northwest European Subboreal Province, and probably the northern Ural Mountains of the Boreal Realm.

The lower assemblage consists of Kimmeridgian-basal Tithonian taxa common in the Indo-Southwest Pacific Province: Phylloceratidae, Taramelliceras, Katroliceras, Pachysphinctes, Lithacoceras, and
\end{abstract}


Aspidoceras (s. str.), with several species identical to those in the upper assemblage, as well as Hybonoticeras pressulum, an index of the (lower) Beckeri Standard Zone in (Sub-) Mediterranean Europe. These beds are probably contemporaneous with the Madagascan " "Zone of Aspidoceras longispinum and alterneplicatus" and with the "1st Katrol Assemblage" of Kachchh. The other similar northeast African faunas need reinvestigation.

The basal Tithonian is probably disconformably overlain by the mid-Neocomian Freretown Limestone Group, with the hiatus spanning most of the Tithonian and the basal Cretaceous.

\section{Introduction}

Recent advances in our understanding of the earth's crustal behaviour have resulted in the rejuvenation of the "continental drift"' hypothesis. It is therefore desirable to take a fresh look at the palaeobiogeographic data and their compatibility with the pre-drift reconstructions.

Some of the areas greatly affected by the early Mesozoic break-up of Gondwanaland are the east coast of Africa, Madagascar, peninsular India, Antarctica, and Australasia. Our knowledge of the Jurassic biostratigraphy and palaeobiogeography of these areas is, however, far from perfect and, for the eastern part of the Jurassic Tethys, dates largely from the late 19th and early 20th centuries. Important beginnings toward a revision of the late Jurassic faunas in some of these areas have been made in the last three decades, beginning with Arkell's (1956) grand synthesis of the World Jurassic. For instance, the fauna of the Spiti Shales in the Himalayas, previously known only from the works of Uhlig (1903, 1910), was recently in part re-collected and described by Helmstaedt (1969) and Mouterde (1971). Some of the famous Jurassic faunas of Kachchh described by Spath (1927-33) were re-examined by Agrawal (1956, 1957). Contributions by Stevens (1963a, 1963b, 1965, 1967, 1968, 1971), Westermann and Getty (1970), and others (see references in Sato, 1975) have advanced our understanding of the palaeobiogeography and biostratigraphy of the Australasian region. The Jurassic of Madagascar has been the subject of several monographic works by Besairie and Collignon (1956), Collignon (1959, 1960, 1962), and Besairie (1936, 1972), while the Ethiopian fauna was investigated by Zeiss $(1971,1974)$. The ammonite-bearing intervals of the Tendaguru Group of Tanzania were studied by Zwierzicky (1914) and Dietrich $(1925,1933)$ and are in need of revision. Dr. M.K. Howarth (pers. comm.) of the British Museum has re-examined the known ammonite occurrences of Tanzania and will revise the faunas.

It was therefore considered highly appropriate to reinvestigate the Jurassic ammonite faunas of Kenya hitherto known mainly through the works of Beyrich (1877, 1878), Futterer (1894), Dacqué (1910), Gregory (1921), and Spath (1930a), and MacKinnon Wood $(1930,1938)$ in the "McKinnon Wood" monographs. One of us (Westermann) visited coastal Kenya during his sabbatical leave in 1973 with a view to reinvestigating the Middle and Upper Jurassic biostratigraphy and subsequently reported on the Bajocian ammonoid fauna (Westermann, 1975). In the present paper we describe some important new faunal elements from the Upper 


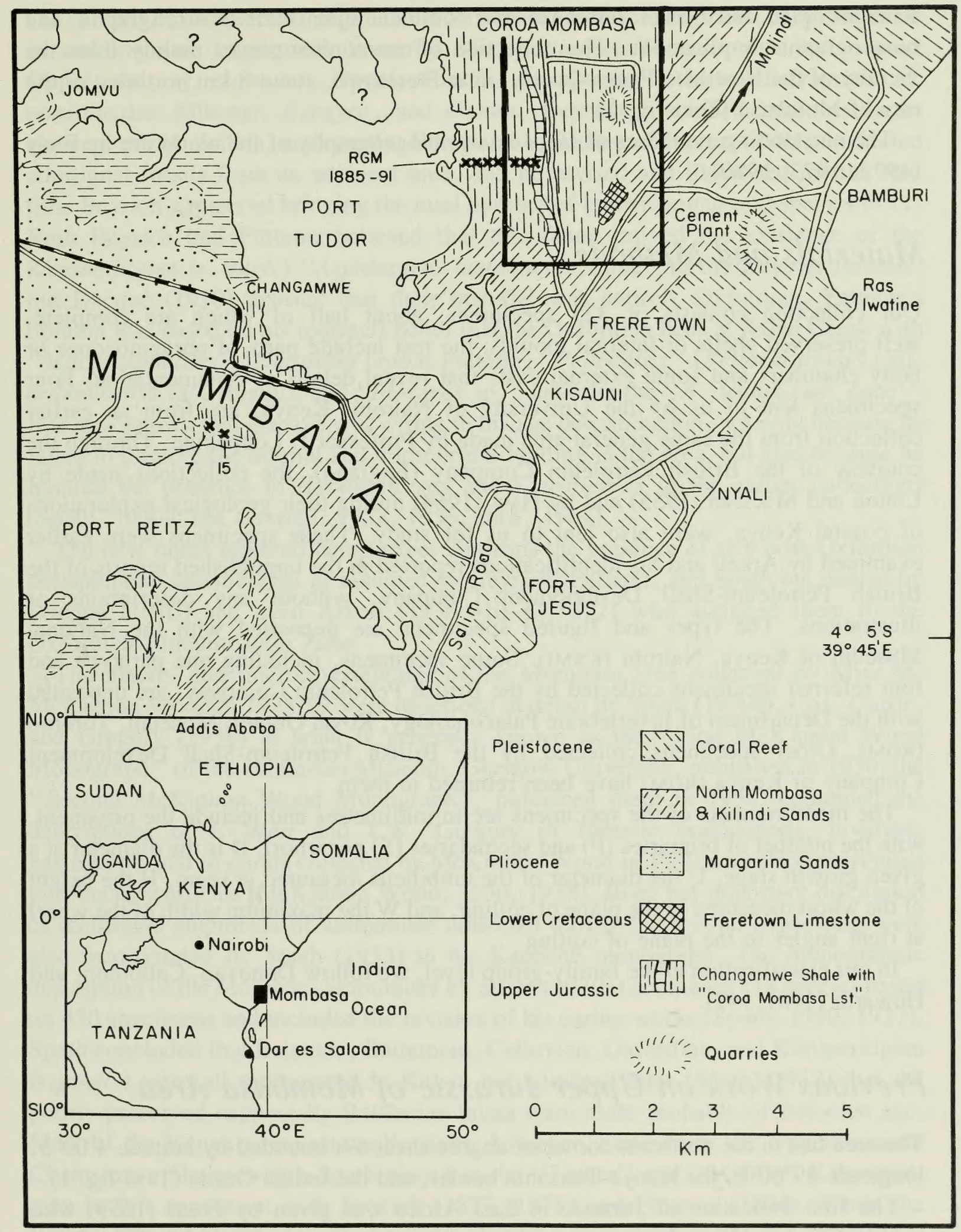

Text-fig. 1 Locality map and geological map of the Mombasa area. The study area lies within the heavy rectangle 1 to $3 \mathrm{~km}$ north of Freretown. 
Kimmeridgian and Lower Tithonian and comment upon their biostratigraphic and biogeographic implications. The collection of ammonites comes mainly from the vicinity of the New Mto Panga Quarry, near Freretown, about $8 \mathrm{~km}$ northeast of the city of Mombasa (Text-fig. 1).

The outstanding syntheses of late Jurassic biogeography of the world are by Enay $(1972,1973,1980)$.

\section{Materials and Methods}

Our collection consists of 325 specimens, about half of which are complete, well-preserved shells or internal moulds; the rest include parts of phragmocones or body chambers and some external casts that reveal details of ornamentation. Four specimens lent to us by the University of Nairobi, Kenya, are from an earlier collection from the same general area made by Professor I. Loupekine. Through the courtesy of the British Petroleum Company (England), the collections made by Linton and Maclean (1955) and by Haw (1964) during their geological explorations of coastal Kenya, were also lent to us for study. These specimens were earlier examined by Arkell and his identifications reported in the unpublished reports of the British Petroleum-Shell Development Company, without any descriptions or illustrations. The types and figured specimens are deposited with the National Museum of Kenya, Nairobi (KNMI). Some specimens, including one paratype and four referred specimens collected by the British Petroleum Company, are deposited with the Department of Invertebrate Palaeontology, Royal Ontario Museum, Toronto (ROM). Other specimens collected by the British Petroleum-Shell Development Company of Kenya (RGM) have been returned to them.

The measurements of the specimens are in millimetres and include the ornament, with the number of primaries (P) and secondaries (S) per whorl. D is the diameter at a given growth stage, $\mathrm{U}$ the diameter of the umbilicus measured at seam, $\mathrm{H}$ the height of the whorl measured in the plane of coiling, and $\mathrm{W}$ the maximum width of the whorl at right angles to the plane of coiling.

In our classification at the family-group level, we follow Donovan, Callomon, and Howarth (1981:149).

\section{Previous Work on Upper Jurassic of Mombasa Area}

The area lies in the northeast corner of degree sheet 69 , bounded by latitude $4^{\circ} 00^{\prime} \mathrm{S}$, longitude $39^{\circ} 00^{\prime} \mathrm{E}$, the Kenya-Tanzania border, and the Indian Ocean (Text-fig. 1).

The first indication of Jurassic in East Africa was given by Fraas (1859) who misidentified an Upper Jurassic ammonite collected by the missionary Mr. Krapf with the Callovian "Ammonites annularis athleta" (= Ammonites annularis of Beyrich, 1877 = Perisphinctes (Dichotomosphinctes) krapfi Dacqué 1910). Beyrich (1877) recorded without illustrations the following species collected by Hildebrandt near Mombasa, "about 2 English Miles from the sea coast': Phylloceras cf. silesiacum (Oppel), Lytoceras cf. rex Waagen, Aspidoceras iphiceroides Waagen, and Ammonites [Hybonoticeras] hildebrandti sp. nov. He concluded that "Malm" was present in the Mombasa area and correctly compared this fauna with that of the Katrol Sandstone of Kachchh (Cutch), India which had just been described by Waagen 
(1873-75). From a second shipment of Mombasa molluscs, Beyrich (1878) recorded in addition Am. longispinus Sowerby, Am. pottingeri Waagen, Am. trachynotus Oppel, Am. cf. montanus Oppel, Nautilus hexagonus Sowerby, Belemnites cf. semisulcatus Münster, Exogyra, and Ostrea. Beyrich concluded that this fauna showed partly Indian and partly European affinities. Futterer (1894) collected additional fossils from an adjacent area, and he revised and illustrated for the first time Beyrich's material bringing the total number of known ammonoid species to 11 . Both Beyrich and Futterer believed that this fauna proved the existence of the Kimmeridgian (s. angl.) 'Aspidoceras acanthicum Zone'" in the Kenyan Jurassic, but Dacque (1910) insisted that their material was entirely Oxfordian. Futterer's opinion was based on his (correct) belief that the Oxfordian beds at Rabai Creek with "Macrocephalites" [Dhosaites] rabai Futterer, "Peltoceras" [Peltoceratoides] aff. arduennense (d'Orbigny), and "Idoceras sp." underlie the "A. acanthicum Zone". It is now known that Dacque was wrong in his age determination, not only because he failed to observe the normal and transcurrent faulting in the area, but also because he ignored the presence of Hybonoticeras and Katroliceras in the earlier collections (Spath, 1930a: see Caswell, 1953, 1956; Haw, 1964).

The new fauna reported here further confirms the presence of rich post-Oxfordian perisphinctid assemblages as assumed by Beyrich, Futterer, and Spath but denied by Dacqué (1910) and even Arkell $(1956: 310-11,322)$ who assigned them to the Oxfordian Bimammatum Zone.

The macro- and microinvertebrates of the Mombasa area collected by Miss M. McKinnon Wood in 1928/29 were described in detail by Spath (1930a), Cox, Currie, and Gregory (1930) in what is generally known as the "First McKinnon Wood Monograph" of the Hunterian Museum, Glasgow University, published in 1930; the "Second McKinnon Wood Monograph", published there in 1938, contained the descriptions of J. Weir and J.W. Gregory of Jurassic brachiopods, bivalves, gastropods, and of corals collected by McKinnon Wood in 1930 who also contributed introductory articles (McKinnon Wood, 1930, 1938). Brief but important discussion of additional shipments of ammonites collected during the second expedition were also incorporated by Spath (1933) in his Kachchh monograph. The monographic description of the Mombasa ammonites by Spath (1930a) contained 118 species based on 450 specimens and included the revision of his earlier works (Spath, 1920, 1927). Spath concluded that Bajocian, Bathonian, Callovian, Oxfordian, and Kimmeridgian ( $s$. angl.) were all represented in Kenya but admitted later (Spath, 1933) that the poorly preserved supposedly Bathonian fauna were more probably of Bajocian age. Most of the Kenya ammonite collections, however, came from the Upper Jurassic Changamwe Shales which Spath placed in the "Lower" and "Middle" Kimmeridgian in full agreement with Beyrich $(1877,1878)$ and Futterer (1894). While the Lower Kimmeridgian (s. angl.) was clearly represented with the "Streblites tenuilobatus" Zone or "A. acanthicum Zone", Spath tentatively dated Katroliceras pottingeri, Taramelliceras cf. kachhense, and several species of Hybonoticeras as "Middle" Kimmeridgian (s. angl.) Beckeri Zone. The material was, however, not well preserved.

Gregory (1930) interpreted the faunal data of Spath (1930a) as implying that there was no free connection between the coastal areas of East Africa and those of Kachchh. However, after analysis of the Kachchh fauna, Spath (1933:815) stated that "there is distinctly greater similarity between the Jurassic faunas of Kachchh and 
those of the neighbourhood of Mombasa." The identification at the species level of many ammonites, as shown by Spath (1930a) and by the authors in the present report, strongly supports the view of an open sea connection between the Kachchh and the Mombasa areas. Arkell (1956:321) stated that, as elsewhere, there was much less local differentiation of biofacies from Callovian to the Middle Kimmeridgian ( $s$. angl.), and that therefore the Mombasa Coast and the Trans-Erythraean Trough were in free communication with both Kachchh and Europe.

In a brief regional description, Maufe in 1908 (fide Gregory, 1921) introduced the first rock-stratigraphic term, that is "Changamwe Shales", for the entire thick Jurassic shale sequence outcropping on the Changamwe Peninsula and including the upper part of the basal massive limestones. The first detailed stratigraphic work was carried out by Gregory (1921) who subdivided this sequence into five formations: Kambe Limestone, Kibiongoni Beds, Miritini Shales, Rabai Shales, and the Changamwe Shales, the last of which he believed belonged entirely in the "Corallian" [Upper Oxfordian]. McKinnon Wood (1930) added the "Coroa Mombasa and Other Limestones" below the restricted Changamwe Shales and placed the last formation in the "Lower and Middle Kimmeridgian" (= Kimmeridgian $s$. str.; to Beckeri Zone, according to Spath, 1930). She also added the "PreBathonian" or Mwachi Shales (McKinnon Wood, 1938) at the base of the sequence.

Caswell (1953, 1956), in revising McKinnon Wood's Jurassic succession, incorporated the Coroa Mombasa and Other Limestones in the Changamwe Shales because of their lenticular nature, and grouped the very similar Miritini, Rabai, and Changamwe shales together as "Upper Jurassic Shales" which he also dated as Callovian to Middle Kimmeridgian (s. angl.) following Spath (1930a) and McKinnon Wood (1930). He also considered the Kibiongoni Beds as a lateral facies development of the Bajocian-Bathonian Kambe Limestone (upper part).

Linton and Maclean (1955) argued that "the names Changamwe and Coroa Mombasa for groups are ridiculously misleading as the so-called Coroa Mombasa Shales outcrop around Changamwe and the Changamwe Shales over the Coroa Mombasa." They also doubted the existence of the so-called Rabai Shales, and included all in the single unit "Upper Jurassic Shales". South of the Coroa Mombasa hills, the thickness of these marine shales was estimated at about $1670 \mathrm{~m}$. The lower four-fifths (c. $1400 \mathrm{~m}$ ) were placed in the Callovian and Oxfordian, and only the upper one-fifth (c. $350 \mathrm{~m}$ ) in the Lower and Middle (Beckeri Zone) Kimmeridgian (s. angl.), according to the identification and dating of the ammonite faunas by Arkell (in Linton and Maclean, 1955). The marine shales conformably overlie and pass into the nonmarine, presumably Lower Callovian Kibiongoni Beds consisting of at least $180 \mathrm{~m}$ of interbedded sandy shales and sandstones. Although Linton and Maclean suggested that these "Beds" can be "regarded as the basal beds of the Jurassic shales," they are retained as a mappable distinct unit. The Kibiongoni Beds lie disconformably and, at least locally, with basal conglomerate on the BajocianBathonian Kambe Limestone Series. Walters and Linton (1973) followed this scheme, but separated about the upper $30 \mathrm{~m}$ from the "Upper Jurassic Shale" as "Aptian-Neocomian Shale". Their estimates for stratigraphic thicknesses were probably adopted from Linton and Maclean.

The geology was described by Caswell (1953, map sheet Mombasa-Kwale; 1956, map sheet Kilifi-Mazeras, with revision of Mombasa-Kwale area; Text-fig. 1). He distinguished the Permo-Triassic Daruma Sandstone Series, the Jurassic rocks, the 
early Cretaceous Freretown Limestone, and the Cenozoic rocks, separated by unconformities (Table 1). The regional dip is said to be gently eastward toward the ocean; however, north of the Nairobi-Mombasa highway, the dip is more often in the opposite direction toward the southwest, such as in the Freretown area. Large-scale slump structures also occur.

Westermann (1975), in the latest paper on the Mombasa Jurassic, re-examined the Kambe Limestone Group and dated it mainly as Bajocian; the Kibiongoni Beds were placed mainly in the Bathonian, reaching possibly into the basal Callovian.

In our opinion, the elimination of all formational names as suggested by Caswell (1953, 1956) and carried out by Linton and Maclean (1955) was not justified; nor is the replacement name "Upper Jurassic Shales" a proper lithostratigraphic term. Although they are probably correct in withdrawing the names "Coroa Mombasa" (lenticular limestones of different ages) and "Rabai Shales" (lower part of the essentially uniform shale sequence), the Changamwe Shales remain a perfectly valid and useful unit similar to the original definiton (Maufe, 1908, fide Gregory, 1921); in fact, the "Upper Jurassic Shales" of Linton and Maclean (1955) are completely synonymous with the Changamwe Shales, except for their basal parts. The Changamwe Shales were originally exposed extensively on the Changamwe Peninsula during and for a time after the construction of the Uganda railroad. Recently, a large new outcrop was cut along the southern shore of Mombasa harbour to accommodate the new docking facilities (our loc. 15). The fact that during Linton and Maclean's time the outcrops were restricted mainly to the area of the Coroa Mombasa hills north of Freretown does not invalidate the formational name.

While the Kambe Limestone Series and the superjacent Kibiongoni Beds are clearly distinct formations, the separation of the Miritini Shale from the basal Changamwe Shale is doubtful, pending further studies; their original distinction was apparently based mainly on the different ammonite fauna. Although also consisting primarily of shales with concretions, the Miritini includes arenaceous limestone, which is well exposed along the new Mombasa road on the Changamwe Peninsula, and is thus apparently unlike the higher shales. This basal unit may also be separated by a marked hiatus, the lithic expression of which, however, remains unknown. The base of the Miritini Shale has locally a boulder bed with derived Kambe Limestone and Mazeras Sandstone, probably due to submarine slumping rather than to transgression. The fauna of the Miritini Shale as described by Spath (1930a) includes a rich assemblage of perisphinctids and macrocephalitids, together with some representatives of the Hecticoceratidae, Oppeliidae, Phylloceratidae and Lytoceratidae. Spath concluded (1930a:65) that this is "unmistakably Callovian and probably includes the upper macrocephalus zone and perhaps part of the anceps bed, above, although there is no trace of a Reineckeia." One of us (Westermann) has re-collected from this locality and found in addition a single fragment, probably of Pachyceras; this supports the late Lower Callovian to early Middle Callovian age of this fauna. Late Middle and Upper Callovian faunas are unknown here and the presence of Lower Oxfordian is questionable, so that beds of this age may not exist or may be merely undiscovered. Much more field work is needed in this area of incomplete exposure and poorly known fault structures.

The Changamwe Shales (s. str., without Miritini Shales) are estimated to be very approximately $1000 \mathrm{~m}$ thick. They consist of dark grey, brownish weathering shales, silty to sandy, with ammonites often in concretions or septarian nodules, and of 


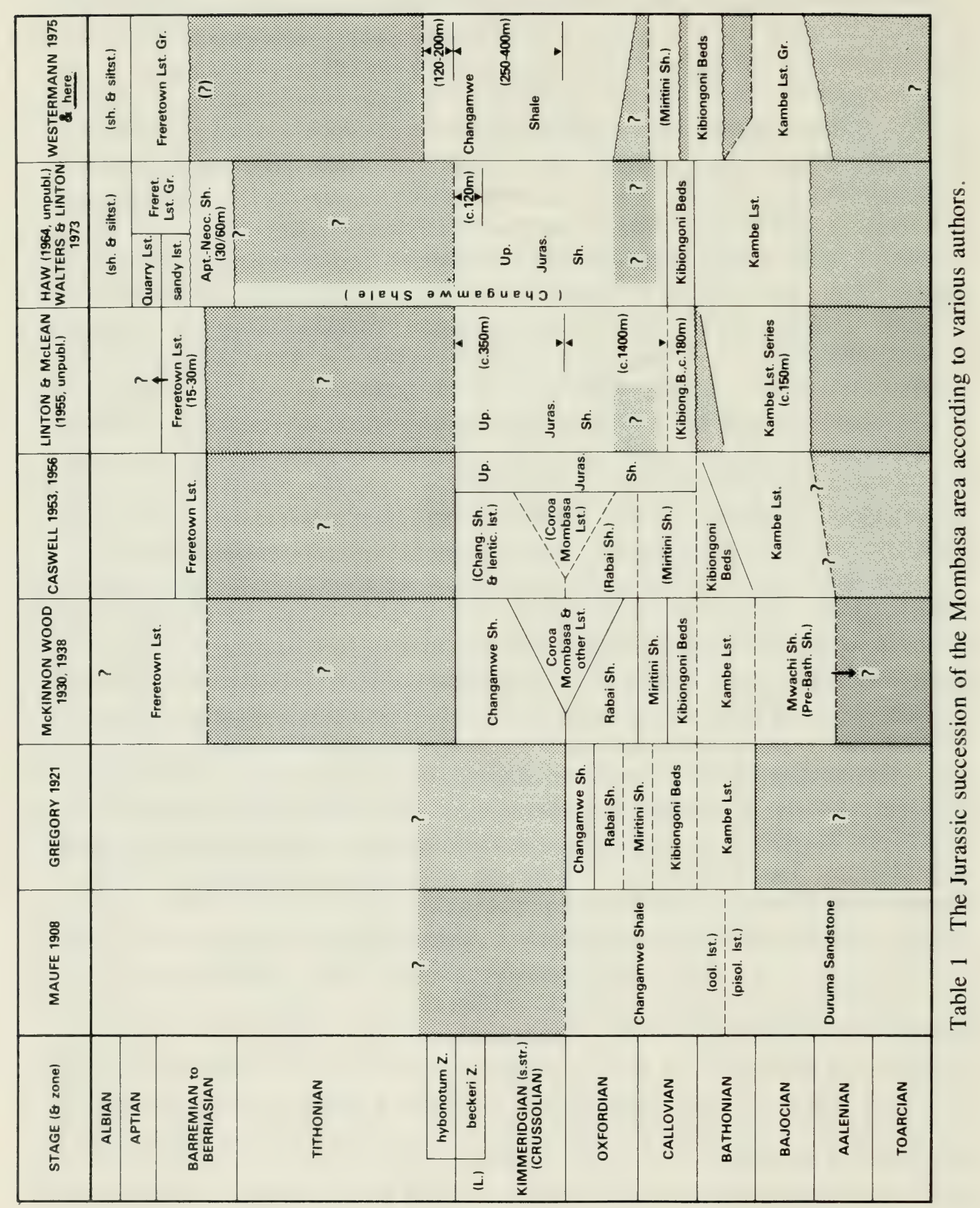


lenticular interbeds of grey limestone and siltstone. The lower part of the formation bears the Indo-Southwest Pacific Mayaitinae fauna, with Perisphinctes (s. l.), Mayaites (including Epimayaites), Dhosaites, and Progreyiceras, all of which Arkell (1956:322-23) dated as Transversarium Standard Zone [ $\simeq$ Plicatilis Zone], Middle Oxfordian. However, the Lower Oxfordian Cordatum Chronozone seems also to be present at an undetermined level as indicated by the single Parawedekindia sp. and Euaspidoceras cf. acuticostatum (Young and Bird) (Arkell, 1956). This fauna has also been re-collected but is not being revised here since studies of the similar Indonesian fauna have been initiated by one of us (Westermann et al., 1978).

The late Kimmeridgian to basal Tithonian assemblage of the middle and upper parts of the Changamwe Shales is discussed below in detail.

\section{Upper Jurassic in Vicinity of Freretown}

\section{PREVIOUS WORK}

Since Cretaceous outcrop is exceedingly rare in the marine embayment of Kenya, Haw (1964) reinvestigated the stratigraphy of the Freretown area, especially in the light of the microfaunas. According to Haw's unpublished report and the accompanying maps (partly reproduced here with modification, by permission of the British Petroleum Company; Text-figs. 2, 3), the following stratigraphic units are exposed in the Freretown-Mto Panga area:

$<30$ Shales, massive calcareous grey with occasional silty beds, sandstone and layers of hard calcareous mudstone to argillaceous limestone. Rich planktonic microfauna and benthic coral-bivalve fauna. Albian.

(5 m) Sandstone, hard, calcareous, fine-grained.

$25 \mathrm{~m}$ Mudstone, soft, clayey, calcareous. - (Upper) Aptian.

Freretown Limestone Group, Freretown Limestone s.s.:

$8 \mathrm{~m} \quad$ Detrital limestone, very finely calcarenitic, bioclastic, some interclastic sparite, generally well bedded but many bedding planes irregular (minor diastems); at top with silty interbeds. Coral-bivalve assemblage mainly near top; limestones with Orbitolinoides bulgarica janeshci.

- (Barremian? - Lower) Aptian.

Freretown Limestone Group, lower part:

(5 m) Silty, sparry limestone. Abundant macrofossils: Exogyra minos, Ostrea, corals. - “Neocomian”.

Changamwe Shales:

$30 \mathrm{~m}$

Massive dark shales, slightly calcareous with occasional calcareous

$(60 \mathrm{~m}$ partings (concretions absent). With rare ammonites, that is, "Groeaccording to Haw, bericeras" [ = Procraspedites, Lower Tithonian] "?Pterolytoceras" fig. 4) [?Tith.-Valang.]; microfauna contains "Cretaceous Marssonella and Gyroidina in an otherwise Kimmeridgian shale-type assemblage." - 


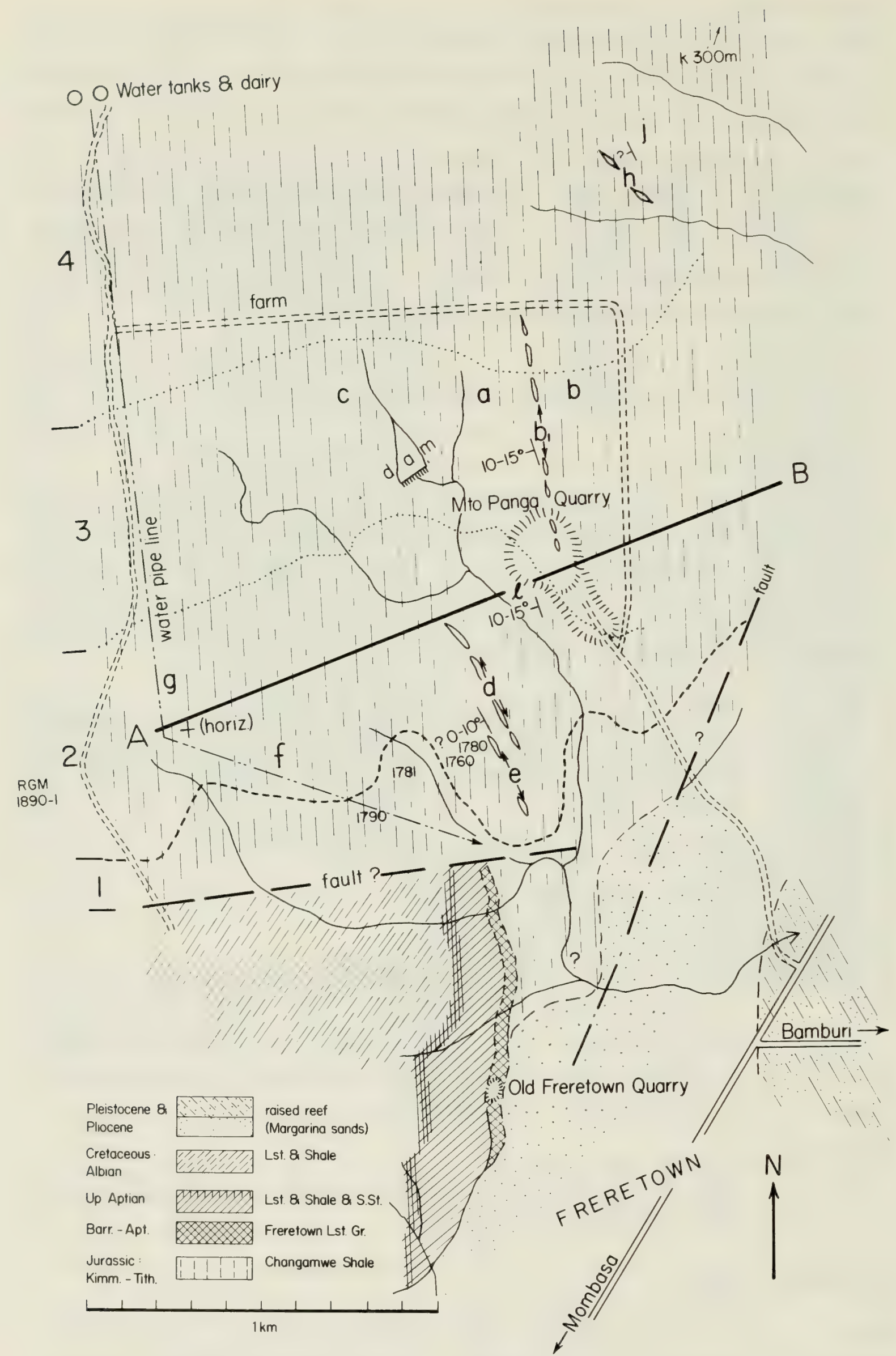

Text-fig. 2 Geological sketch map of the area in the vicinity of the New Mto Panga Quarry north of Freretown (modified after Haw 1964, with permission of the British Petroleum Oil Company). 


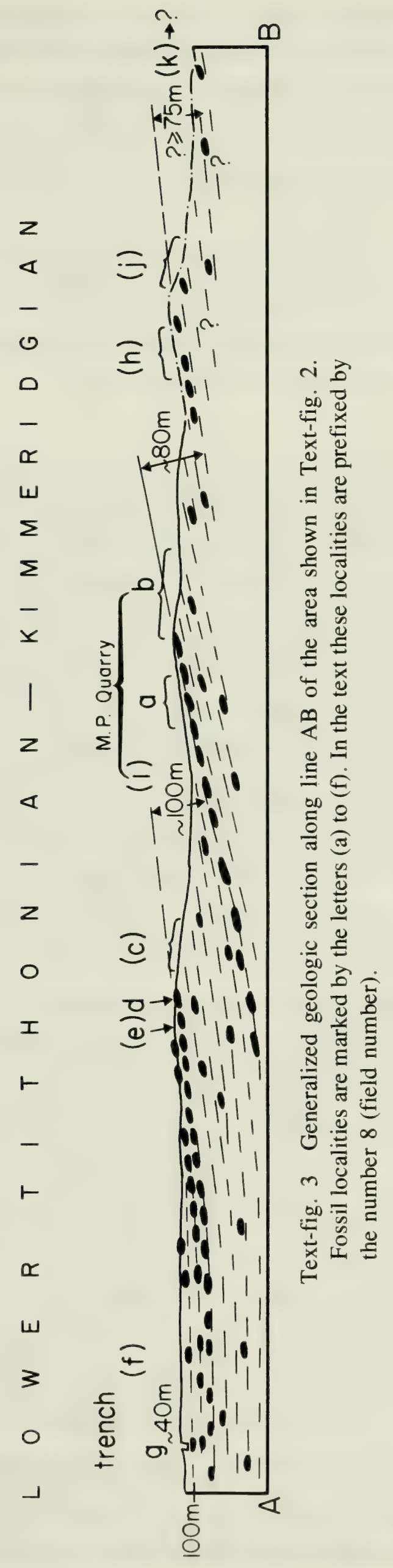


"Neocomian". Sample No. 1781 with the supposed Berriasian "Groebericeras", from about the lower third of the section, was, however, said to have a Kimmeridgian microfauna, while the only higher Sample No. 1790 in the middle of the "Neocomian" interval yielded a rather poor microfossil assemblage dated as "Kimmeridgian-Neocomian".

(250 m?) Massive shales, dark gray with greenish blue (fresh), generally slightly calcareous, and with occasional very impersistent muddy limestones with very calcareous shales and fairly common limey concretions and septarian nodules. Frequently containing ammonites. — "Lower Kimmeridgian-Tithonian".

\section{Remarks}

Haw (1964) placed the upper $40 / 120 \mathrm{~m}$ of this shale series (40 m according to fig. 4; $120 \mathrm{~m}$ according to text and fig. 3) in the "Middle-Upper Kimmeridgian" and "Tithonian". However, the critical "Tithonian" Sample No. 1760 contained only a "Physodoceras 1" identified and dated "Kimmeridgian" by Eames and Clarke (1964), while Sample No. 1780 of the supposed "Upper Kimmeridgian" included the same ammonite species together with a rich microfauna identified and dated as "Kimmeridgian" (Eames and Clarke, 1964). The dating of the entire fauna was actually based on the associated ammonites, since the microfauna "is not distinguishable from the Lower Neocomian samples apart from the absence of Cretaceous genera and species" (Eames and Clarke, 1964).

The boundary Lower/Middle Kimmeridgian (s. angl.) was placed according to ammonite evidence, that is, the assumed restriction of Aspidoceras iphiceroides and Lithacoceras kenyaense to the Lower Kimmeridgian (s.angl.). The approximate boundary was inferred to run with general northwest-southeast direction through the New Mto Panga Quarry. This coincides approximately with our KimmeridgianTithonian boundary.

We have found another specimen of Procraspedites ["Groebericeras"] in an assemblage of the Hybonotum Zone, basal Tithonian. Since the supposed ammonite evidence for a Neocomian age of the uppermost Changamwe Shales does not exist, the evidence rests on the remaining fauna. The (other) megafauna consists of long-ranging corals and bivalves and a Hibolites, to which Eames and Clarke (1964) attribute "Neocomian" (1 sp.), "Neocomian-Aptian" (3 spp.), and “Lower Cretaceous"' (7 spp.) ages. The microfauna was said to indicate mostly Albian age; but the lowermost Sample No. 1778 came from the lower Freretown Limestone which was dated "Neocomian". Evidence for a "Neocomian" age of the shales subjacent to the Freretown Limestone was, therefore, entirely dependent on the microfauna, contrary to the recent statement by Walters and Linton (1973:140). The "Lower Neocomian" date given by Eames and Clarke (1964) rests on the association of long-ranging Kimmeridgian-Neocomian and Cretaceous foraminifera species, for example, Ammodiscus, Gaudryina, Gyroidina, Marssonella, Bathysiphon, Lenticulina, and his "Lower", rather than "Upper", Neocomian date was apparently based on the supposed occurrence of Groebericeras rather than on his own work.

The stratigraphic interval between the base of the Freretown Limestone and the supposedly Lower Neocomian samples is, furthermore, unknown. The limestones 
outcrop only in the small Freretown quarry and the thickness of the uppermost Changamwe Shales has probably been overestimated previously, being based on an assumed 10- to 15-degree regional southwest dip. The new trench for the water pipeline (Text-fig. 2) directly north of the Cretaceous exposures shows horizontality. We suggest therefore that the early Cretaceous samples investigated by Eames 1) came from immediately subjacent, if not from the base of the Freretown Limestone and 2) belong in the Upper, rather than Lower, Neocomian. Consequently, the most probable position of the disconformity remains near the base of the Freretown Limestone Group, with the hiatus spanning "Middle" Tithonian to Lower Neocomian.

\section{NEW WORK}

In the vicinity of the New Mto Panga Quarry, the flat-lying Changamwe Shale forms a gently undulating surface dissected by a few shallow valleys. Although the shales are mostly covered with talus and alluvium, they are exposed in the quarry. Several bands of small to large calcareous concretions, however, crop out frequently, often forming the tops of small hills or ledges along gentle grass-covered slopes. They are best exposed and fossils most easily found where the pastures have been freshly burned. The clay quarry, however, is operated by surface scraping, since its depth is limited by the high groundwater level. It is several hundred metres in subcircular diameter, but up to only several metres deep and the bedding structures of the soft, weathered shale have been obliterated. The only possible useful markers to determine attitudes are therefore the layers of concretions and lenticular limestones. Fortunately, a trench 1 to $1.5 \mathrm{~m}$ deep had been excavated for a water pipeline along the western edge of our area, exposing the flat-lying shales with concretions continuously for more than a kilometre (Text-fig. 2).

The total section, therefore, can only be reconstructed from disjunct outcrops of concretionary layers, and some mostly small shale exposures. Consequently, the measurement of stratigraphic thickness is subject to considerable error. In view of this, we estimate the thickness of the Changamwe Shale of the Freretown area to be somewhere between $220 \mathrm{~m}$ and $400 \mathrm{~m}$. At least another $100 \mathrm{~m}$ of Kimmeridgian shales and several hundred metres of Oxfordian shales are present around Mombasa.

Although the attitudes are rather persistent, with horizontality in the southwest (and ?west where the trench is parallel to supposed strike) and a dip of 10 to 15 degrees west-southwest around the quarry and probably to the north (also the Freretown Limestone in the south), faults may remain undetected under the poor outcrop conditions. Fortunately, the main traverse is from south-southwest to north-northeast, which is parallel to the major normal fault system of the Mombasa area, for example, the Freretown Fault (Caswell, 1956, fig. 14) and the "Hypothetical fault" of Haw (1964, figs. 1, 2). The smaller east-west fault between the "Upper Jurassic Shales" and the Freretown Limestone Group (Linton and Maclean, 1955, fig. 2; Haw. 1964) also does not affect our stratigraphic section (locs. 8a-8k).

\section{Localities 8a-8k: Freretown Section (Text-fig. 2, Table 2)}

Vicinity of New Mto Panga Quarry of Bamburi Portland Cement Works, 1 to $3 \mathrm{~km}$ north of Freretown, Mombasa area (Text-fig. 1). The locality descriptions are 
arranged stratigraphically (top to bottom) and the nonexposed intervals are indicated in parentheses (Text-figs. 2, 3). The species are listed in Table 2.

Freretown Limestone:

For description see under Previous Work.

Changamwe Shales:

(10 to $? 50 \mathrm{~m})$

8f-8g: Greyish shales with some large calcareous concretions, exposed in 5 to $8 \mathrm{~m}$ pipeline trench; attitude horizontal (at least at bend of trench) to near-horizontal. Holcophylloceras, Procraspedites, Hybonoticeras cf. hybonotum.

(30 to $50 \mathrm{~m}$ shales)

8e: $\quad$ Layer of calcareous concretions and lenticular siltstone forming flat 0.5 to $1 \mathrm{~m}$ ridge; probably with gentle southwest dip. Fossiliferous: abundant Holcophylloceras, Phanerostephanus (Nothostephanus) digoi, and Aspidoceras (Physodoceras), also Gravesia loupekinei and Somalinautilus .

(3 to 5 m "shales")

8d: Layer of siltstone and concretions, exposed on gentle slope; attitude 0.5 to $1 \mathrm{~m}$ near-horizontal. Highly fossiliferous: abundant Phylloceratidae, Aspidoceras (s. str.), Streblites, and Pachysphinctes, also Lytoceratidae, Subdichotomoceras?, A. (Physodoceras), Gravesia loupekinei, Taramelliceras, and Hybonoticeras cf. hybonotum.

80 to $110 \mathrm{~m}$ Greenish and greyish shales with some concretions. Poorly exposed northwest of quarry; lower part in west side of quarry.

8c: Concretions in upper half with: Calliphylloceras, Streblites, Lithacoceras, Pachysphinctes?, Katroliceras, Subdichotomoceras?, Aspidoceras, A. (Physodoceras), and Hybonoticeras hybonotum.

8a $(=8 l=4)$ : Near base moderately abundant: Phylloceratidae, Pterolytoceras, Streblites, Pachysphinctes, Lithacoceras?, Aspidoceras (s. str.), and Hybonoticeras hybonotum.

8b: $\quad$ Poorly exposed, mostly shales with concretions; at top (8b1) irregular 5 to $10 \mathrm{~m}$ lenticular limestone bed and large concretions, dipping $12-15^{\circ} \mathrm{WSW}$. Concretions and limestone moderately fossiliferous: Phylloceratidae, abundant Aspidoceras (s. str.), also Katroliceras, Pachysphinctes, Subdichotomoceras?, Lithacoceras, Hybonoticeras pressulum, and Paracenoceras.

(40 to $70 \mathrm{~m}$ " "shales")

8h: Shales with bands of concretions, slightly exposed on gentle south c. $10 \mathrm{~m}$ slope of hillock several hundred metres north of the bend in the road leading around the quarry; probably with gentle southwest dip. Moderately fossiliferous: Calliphylloceras, Taramelliceras, Pachysphinctes?, Katroliceras, Lithacoceras?, Hybonoticeras pressulum, and abundant Aspidoceras (s. str.). 
8j: $\quad$ Shales with concretions, poorly exposed on the north side of same c. 10 to $15 \mathrm{~m}$ hillock as $8 \mathrm{~h}$. Moderately fossiliferous: Ptychophylloceras, Taramelliceras, Katroliceras?, Pachysphinctes, Hybonoticeras sp.

(?50 to $100 \mathrm{~m})$

8k: $\quad$ Calcareous shales with some concretions in stream cut approximately c. $5 \mathrm{~m} \quad 0.6 \mathrm{~km}$ northeast of $8 \mathrm{~g}$; near-horizontal. Scarce fauna: Aspidoceras (s. str.), Lithacoceras?

Total about 300 to $350 \mathrm{~m}$, closely approximating the earlier estimates for Kimmeridgian (s. angl.).

\section{Locality 15 (Text-fig. 1)}

Changamwe Peninsula, Kipevu, about 400-m-broad cut slope behind the new docking facilities west of the Kipevu Causeway in the northeast corner of Port Reitz. Attitude mostly near-horizontal and dipping east at west end of outcrop. The section is from top.

c. $7 \mathrm{~m}$ Thick lenticular beds of sandstone and siltstone with shaley interbeds and sandstone dykes; unfossiliferous.

$8 \mathrm{~m} \quad$ Shale; unfossiliferous.

$3.5 \mathrm{~m} \quad$ Shale with sandy concretions and ?sedimentary dykes; unfossiliferous.

15c: Blue-grey friable shale; near top moderately fossiliferous: Ptychophyl-

c. $10 \mathrm{~m}$ loceras ptychoicum, Lytoceras fraasi, Pterolytoceras montanum, Perisphinctinae indet., Aspidoceras (Aspidoceras) cf. hoplisum, A. (Physodoceras) cf. avellanum, Taramelliceras cf. kachhense.

15b: Shale with fossiliferous concretions, ferrugineous partings. Pterolytoc. $10 \mathrm{~m}$ ceras ptychoicum, Lytoceras fraasi, Aspidoceras (Pseudowaagenia) aff. haynaldi, Perisphinctidae indet., Belemnopsis tanganensis (Futt.).

15a: Shale with concretions; moderately fossiliferous: ?Pachysphinctes c. $5 \mathrm{~m} \quad$ beyrichi, Streblites habyensis.

Total about $43.5 \mathrm{~m}$.

\section{Locality 7}

Changamwe Peninsula, Kipevu, section cut by main road (from traffic circle) between ridge over railroad and dock gate, 0.2 to $0.5 \mathrm{~km}$ northwest of locality 15 .

c. $10 \mathrm{~m}$ Shales with concretions, topped by some sandstone and siltstones. Probably same beds as included at locality 15 . Moderately fossiliferous: Aspidoceras (Pseudowaagenia) aff. haynaldi (Neumayr), Lithacoceras cf. arussiorum (Dacqué), L. cf. sigali (Collignon), Taramelliceras trachynotum (Oppel)?, Perisphinctidae, ?Pachysphinctes fragments. 


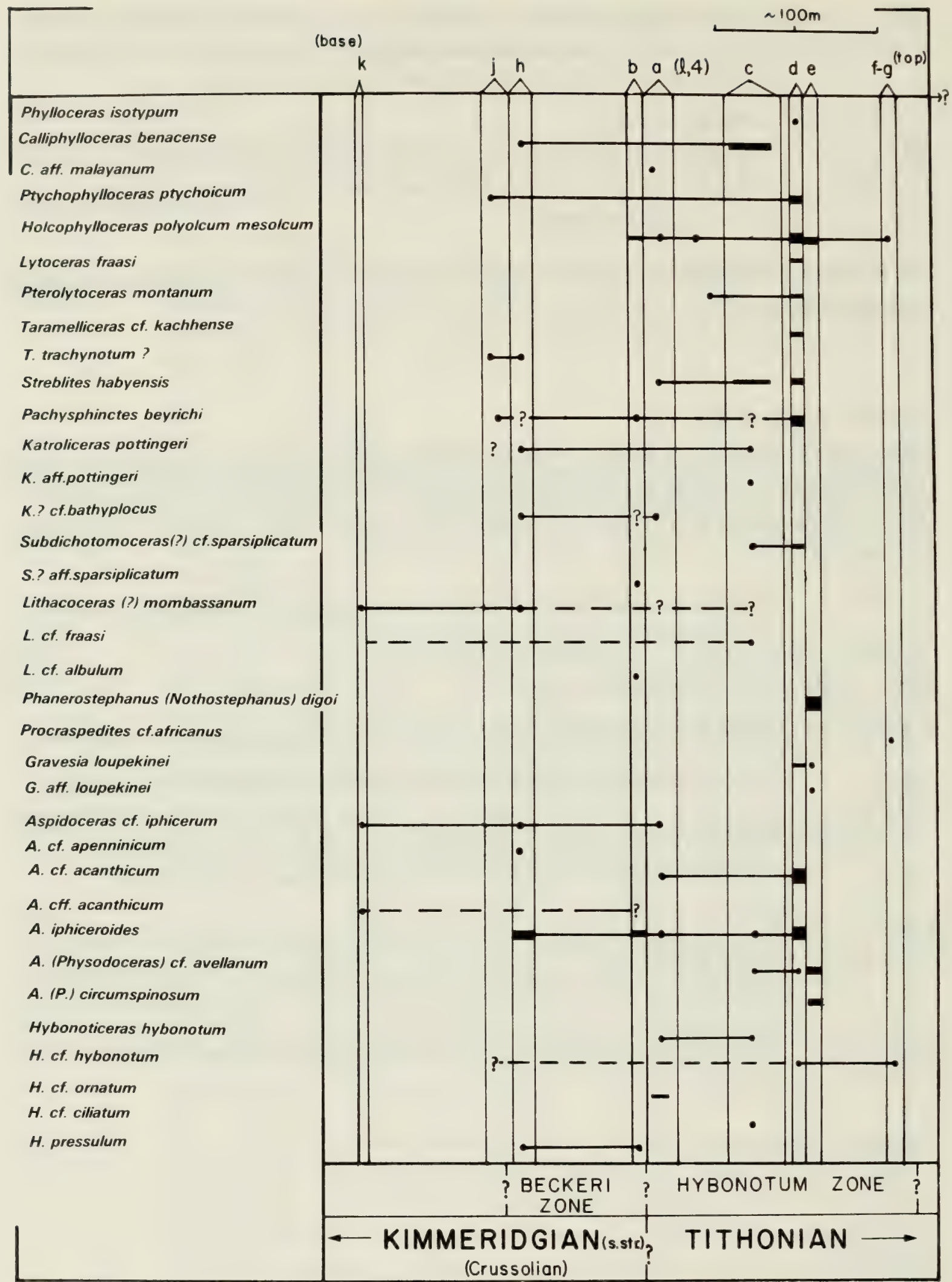

Table 2 The stratigraphic occurrence and ranges of the various species of ammonites within the Kimmeridgian-Tithonian boundary beds of the Mombasa area. The thickness of the lines indicates relative abundance. Dots denote single occurrence. Dashed lines indicate presumed occurrence. Letters a to $\mathrm{k}$ refer to localities indicated in Text-fig. 2. 


\section{Age and Affinity of Freretown Ammonoid Fauna}

\section{INTRODUCTION TO KIMMERIDGIAN AND TITHONIAN STAGES}

The Stages Oxfordian, Kimmeridgian, and Portlandian as defined by d'Orbigny (1842-51) were named on the basis of the faunal elements existent in northwest Europe and can be universally recognized and correlated only up to the top of the Kimmeridgian (s. str.) (Crussolian) Beckeri Zone. The post-Kimmeridgian (s. str. or gall. and s. angl.) stages have been called Portlandian and Volgian in the Boreal Realm and mostly, though not always, Tithonian over the rest of the world (Table 3 ). Disagreements have revolved around the time-stratigraphic and geographic definitions of the stages and the time equivalence of their upper and lower limits (see Verma and Westermann, 1973:159, table 7). Confusion has arisen where, for want of agreement over which name should be used for which realm, the standard English stage names have been used for areas belonging to the Tethyan Realm. Some uniformity and international agreement over stage usage have been achieved as a result of three successive colloquia held in Luxembourg in 1962 (Zeiss, 1962, 1964; Maubeuge, 1964) and 1967 (Zeiss, 1971) and in Budapest in 1969: Kimmeridgian and Portlandian are to be used as originally defined in southern England for areas of northwest Europe, with the boundary between the Rotunda (not Pallasioides) and Albani Standard zones; Tithonian should be used for all areas of Tethys including Submediterranean Europe and all (other) Perigondwanian areas including those formerly ascribed to the Pacific Realm (i.e., Japan, Mexico, Cuba, southern Andes, Antarctica, New Zealand, etc.). The Tithonian faunas are extremely extensive and recognizable over a larger part of the globe than those of Upper Kimmeridgian ( $s$. angl.), Portlandian, and Volgian. They offer, therefore, much greater possibilities of correlation (Enay, 1963:6, 9; 1964, tables 1-4; 1973; Zeiss, 1968, 1977b, 1979, 1982; Oloriz and Tavera, 1981).

The lower limit of the Tithonian Stage, defined by the base of the Hybonotum Standard Zone, is marked by the appearance of Hybonoticeras hybonotum (Oppel) or, for want of this species, by the genus Gravesia, particularly the species $G$. gravesiana (d'Orbigny) (Enay, 1963, 1964, 1972, 1973; Barthel and Geyssant, 1973; Enay and Geyssant, 1975). The upper limit is somewhat more difficult to define and complicated by the fact that it also marks the boundary between the Jurassic and Cretaceous systems. The Volgian corresponds in time to the Tithonian and the zonal correlation is shown by Zeiss $(1968$, tables 5,$6 ; 1974 ; 1983)$. In the entire Tethyan and Perigondwanian Realms, therefore, most of the "Middle Kimmeridgian ( $s$. angl.)" (post-Beckeri Zone) should be included in the Lower Tithonian (s.l.). In the Tethyan and Volgian Realms, the "Lower Kimmeridgian s. angl." thus becomes the Kimmeridgian (s. str.) (Ziegler, 1977), or simply, Kimmeridgian as used here. The use of the substage name Crussolian for this unit was also proposed at the first Luxembourg colloquium in 1962 (Zeiss, 1962, 1964), but has found little acceptance, tending to confuse the matter further.

The Tithonian can be divided into two (Spath, 1950; Arkell, 1956: Zeiss, 1968; Verma and Westermann, 1973; Enay and Geyssant, 1975; Wiedmann, 1980; etc.) or three substages (Donze and Enay, 1961; Enay, 1964, 1972, 1973; Zeiss, 1983). The bipartite subdivision is favoured by us on account of the difficulty of recognizing a distinct “Middle Tithonian" assemblage (Zone of Pseudolissoceras zitteli in Mexico, 


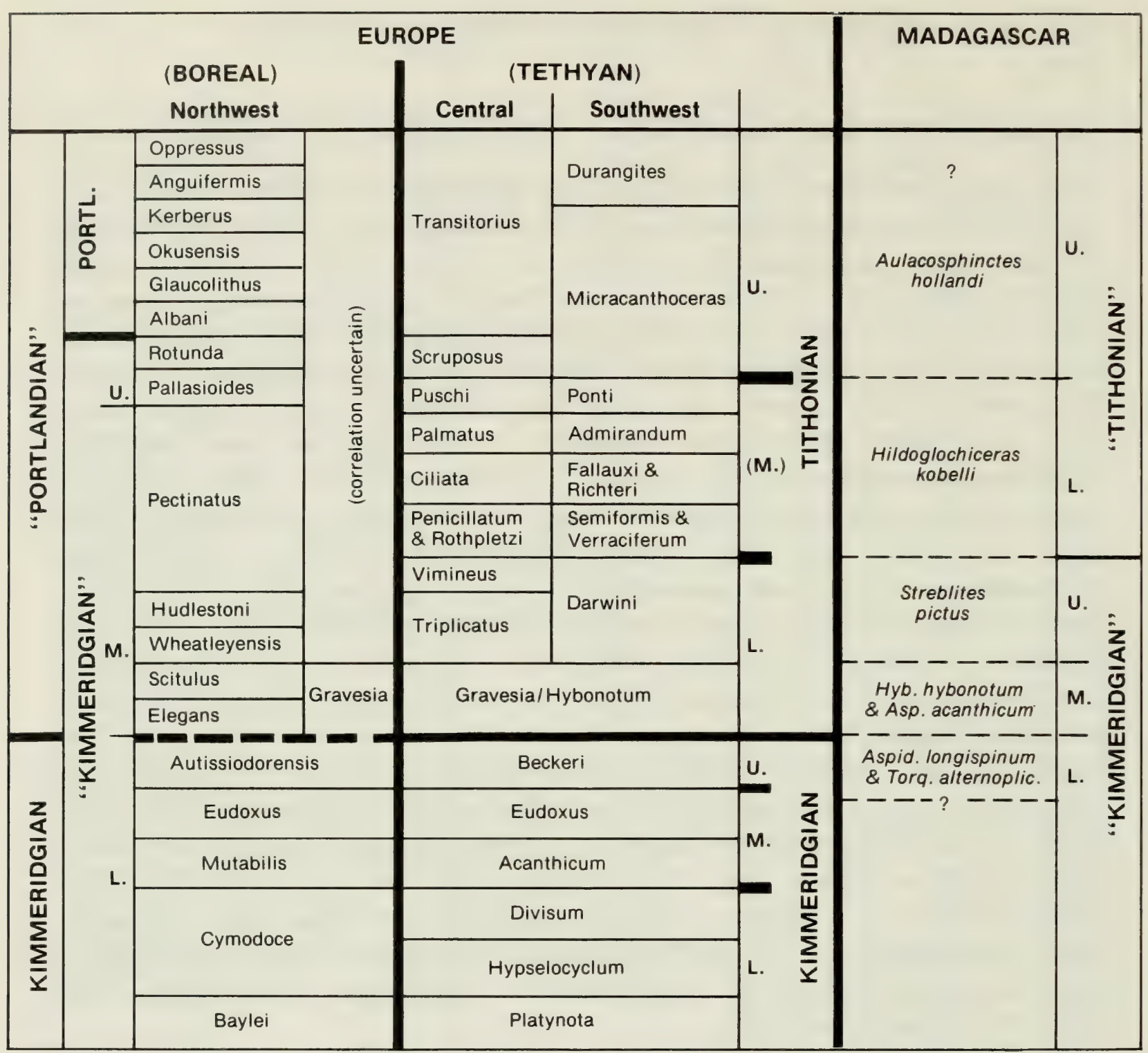

Table 3 Northwest European zones after Casey (1973) and Wimbleton and Cope (1978); central and southern European after Enay and Geyssant (1975), Zeiss (1977b, 1979, 1983), and Oloriz and Tavera (1981); Madagascar after Collignon (1964).

Argentina, and Iraq, Zone of Semiformiceras semiforme in the Alps) in all parts of the globe (Verma and Westermann, 1973, table 4; Enay, 1973, table 1). The recognition of a "Middle" Tithonian assemblage in northern Iraq by Spath (1950) on the basis of Pseudolissoceras zitteli in association with his Phanerostephanus-Nothostephanus fauna, conflicts with our discovery of Hybonoticeras hybonotum and Gravesia loupekinei sp. nov. together with similar faunas from Kenya. As pointed out by Enay (1972), only a bipartite classification is acceptable when utilizing the common elements of correlation; that is, Hildoglochiceras is known from the Himalayas, Madagascar, Tanzania, Cuba, and Mexico; Kossmatia from the Himalayas, Indonesia, Australia, New Zealand, Argentina, Mexico, Texas, and California; and Lytohoplites from Salt Range, Madagascar, Argentina, and Cuba.

\section{AGE OF FRERETOWN FAUNA}

The 220-to-400-m Changamwe Shale at Freretown bears a moderately abundant to highly abundant ammonoid fauna with overlapping vertical ranges in what appears to 
be a rapidly and continuously deposited neritic series (Table 1). The stratigraphic record of the ammonoid taxa is, however, mostly sporadic rather than continuous, with most fossils occurring in a dozen or so horizons of concretions or lenticular limestones and siltstones. This is particularly true of the lower half and near the top of the sequence. Furthermore, the vertical ranges are reasonably well known for fewer than 10 of the 34 recorded taxa, mostly from the highly fossiliferous middle and upper parts of the sections (Table 2).

The ammonoid fauna is relatively uniform throughout the sequence, with several species ranging throughout, for example, the Phylloceratidae Calliphylloceras benacense (Catullo) and Ptychophylloceras ptychoicum (Quenstedt), as well as several Ammonitina, for example, Katroliceras pottingeri (Sow.), and the abundant Aspidoceras iphiceroides Waagen. Many other taxa are represented by single or a few specimens so that their range is unknown (Table 2).

Both a lower and an upper ammonite assemblage can, nevertheless, be clearly distinguished, with a possible narrow overlap in bed $8 \mathrm{~b}$. The upper assemblage is by far the richer in number of specimens and taxa.

\section{Upper assemblage with Gravesia, Phanerostephanus, and Hybonoticeras hybonotum}

This assemblage is characterized by abundant Streblites habyensis Spath, Phanerostephanus (Nothostephanus) digoi sp. nov., Aspidoceras (Aspidoceras) cf. acanthicum (Oppel), and the less abundant Subdichotomoceras? cf. sparsiplicatum (Waagen), Aspidoceras (Physodoceras) cf. avellanum Zittel, A. (P.) circumspinosum (Quenstedt), Gravesia loupekinei sp. nov., Procraspedites cf. africanus (Zwierzicky), Hybonoticeras hybonotum (Oppel), and $H$. cf. ornatum (Spath).

The fauna also includes taxa of questionable age significance, such as Phylloceratina, in particular the rather abundant Holcophylloceras polyolcum (Benecke), and the rather scarce Lytoceratina; as well as the rare Taramelliceras cf. kachhense Spath; Katroliceras pottingeri (Sow.) and K. katrolense (Waagen), of which at least the former ranges downward; Lithococeras cf. fraasi (Dacqué); and Aspidoceras iphiceroides Waagen, which is abundant in both assemblages.

The presence of the two index fossils Hybonoticeras hybonotum and Gravesia securely places this assemblage in the Hybonotum Standard Zone or Gravesia Zone, both of which have previously been essentially restricted to Europe (Zeiss, 1964, 1965, 1977; Enay, 1972, 1973; Sapunov, 1976, 1977; Barthel and Schairer, 1978). $H$. hybonotum in beds $8 \mathrm{a}$ and $8 \mathrm{c}$, and $H$. cf. hybonotum together with Gravesia in bed $8 \mathrm{~d}$ and alone in beds $8 \mathrm{f}$ and $8 \mathrm{~g}$ at the top of the sequence, establish the range of the zone. Even if Gravesia is represented by the new species $G$. loupekinei, the entire, distinct genus is restricted to the Hybonotum Zone throughout its geographic range in Europe, and all previously known species are said to be penecontemporaneous (Barthel, 1959; Ziegler, 1960; Hahn, 1963; Cope and Zeiss, 1964; Enay, 1966, 1973). Gravesia has also been recorded from the Russian platform and western Siberia where it marks the base of the Volgian stage (Zeiss, pers. comm.) The apparent restriction of Gravesia to the narrow stratigraphic interval of beds $8 \mathrm{~d}$ to $8 \mathrm{e}$ may be owing to its relative scarcity. Zeiss (1968) supposed, however, that Gravesia is facies-controlled by shallow neritic to sublittoral limestone; the highly fossiliferous limestone beds of the Freretown sequence are probably an example. The earliest occurrence of $H$. hybonotum (bed $8 \mathrm{a}$ ) is superjacent to the latest record from bed $8 \mathrm{~b}$ of 
$H$. pressulum of the (lower) Beckeri Standard Zone (see below). The zonal (and stage) boundary is therefore between beds $8 \mathrm{a}$ and $8 \mathrm{~b}$. Hybonoticeras ornatum Spath, probably also from bed $8 \mathrm{a}$, occurs in Kachchh, India, in both Hybonoticeras Zones (Spath, 1931). The questionable H. ciliatum Berckhemer and Hölder (1959) from bed $8 \mathrm{c}$ was originally described from the Beckeri Zone of Germany, but the species appears to be known from the holotype and one fragment only and thus is of unknown vertical range. The upper range of Hybonoticeras in Europe coincides with that of Gravesia, that is, the upper boundary of the Hybonotum Zone (Zeiss, 1975).

Of the other taxa apparently characteristic of the upper assemblage, Streblites habyensis occurs also in the Hybonotum Zone of Madagascar (Collignon, 1959), but mainly in the Beckeri Zone of Kachchh (Spath, 1931). Subdichotomoceras? cf. sparsiplicatum (Waagen) occurs also with identical forms in the Tendaguru Group of Tanzania (Zwierzicky, 1914, pl. 8, figs. 1, 2); but its stratigraphic level ("Nerineenschicht") is uncertain since it was found by natives in a river bed supposedly mainly in the "Nerineenschicht" (Janensch and Hennig, 1914:5). Dietrich (1933:20) lists "Perisphinctes sparsiplicatus" from both the Smeei and Nerineen [Nerinella] Beds. His small, figured specimen (pl. 1, fig. 2), however, resembles more closely the dubious nucleus "Perisphinctes latissimus" [Pachysphinctes?] Zwierzicky (1914, pl. 8, fig. 4), found loose, while Dietrich's larger specimen (1933, fig. 4) with similar coarse ribbing comes from the proximity of the Nerinella Bed. Similar poorly preserved specimens were illustrated from the Hybonotum Zone of Madagascar (Collignon, 1959, figs. 4, 7, 8).

Phanerostephanus (Nothostephanus) digoi sp. nov., known only from bed 8e where it occurs in abundance, can be closely compared only with $P$. ( $N$.) kurdistanensis (Spath) and, perhaps, $P$. ( $P$. ) subsenex Spath from a black limestone sequence ("bed i" = $10 \mathrm{~m}$ ) in Kurdistan, Iraq (Spath, 1950). Although Spath placed that assemblage tenatively in the "Middle" [upper Lower] Tithonian, he also reported a Hybonoticeras ex gr. hybonotum of the same preservation which was reported to him to have come from the same interval. We conclude that the $10-\mathrm{m}$ sequence of black limestone at Jebel Gara probably contains more than one zone, including the Hybonotum Zone.

Aspidoceras cf. acanthicum, if identical with that species, appears to differ significantly in age between western Europe and Kenya-Madagascar. The species has been regarded as an index for the Kimmeridgian "Mutabilis-Acanthicum Zone" of eastern France (cf. Contini and Hantzpergue, 1975) and of the Acanthicum Zone in southern Germany (Ziegler, 1977), preceding the Eudoxus and Beckeri Zones (Table 3). In Kenya and Madagascar, this species is abundant in the Hybonotum Zone (Zone of $H$. hybonotum and A. acanthicum of Collignon, 1959). In Kachchh, India, it is rare in the ? Beckeri Zone (Spath, 1931), and probably ranges downward into that zone also in Kenya (Spath, 1930a). The similar A. longispinum (Sow.), occurs in the Eudoxus Zone (Contini and Hantzpergue, 1975) and may be conspecific with the poorly defined $A$. acanthicum (cf. under that species). According to Wiedmann (1980), A . cf. acanthicum occurs also in the Lower Tithonian of Peru.

Aspidoceras (Physodoceras) avellanum occurs also in the Lower Tithonian of Mt. Catria in Italy (Zittel, 1870) and in the Hybonotum Zone of Spain (Enay and Geyssant, 1975). It closely resembles $A$. (P.) pinini (Oppel) from the Solnhofen Limestone, southern Germany, in the same zone. The holotype of $A$. ( $P$. $)$ circumspinosum, however, comes from the Lower Kimmeridgian of Germany (Malm gamma). 
Katroliceras (s. str.) occurs in Submediterranean Europe as early as Eudoxus Zone in southeast France (Contini and Hantzpergue, 1975), but ranges into the lower Hybonotum Zone in southern Franconia, Germany (Zeiss, 1975). The similar subgenus ?Crussoliceras, however, which has been separated generically only recently by some authors (e.g., Contini and Hantzpergue, 1975; Sapunov, 1977; but not Ziegler, 1977), marks already the Divisum and Acanthicum Zones of southeastern France to Bulgaria, where Katroliceras (s. str.) appears to be absent (Sapunov, 1977; Contini and Hantzpergue, 1975). In Madagascar and Kachchh, on the other hand, Katroliceras (s. str.) appears to be restricted to the Hybonotum Zone (Zone of Aspidoceras acanthicum and $H$. hybonotum of Collignon, 1959, and " 2 nd Katrol Assemblage" of Middle Katrol Group of Spath, 1931). The typical $K$. $(K$. katrolense found at Mombasa is also quite abundant in Madagascar and Kachchh and similarly associated with Pachysphinctes. Questionable Katroliceras were also reported from the "1st Katrol Assemblage", basal Katrol Group (c. Beckeri Zone) of Kachchh (Spath, 1931:789), and they may perhaps also be found among the supposed Torquatisphinctes and Pachysphinctes of Collignon (1959) from Madagascar. We have found only one or two specimens of Katroliceras (s. str.), $K$. pottingeri, below the Kimmeridgian-Tithonian boundary bed $8 \mathrm{~b}$. The principal Katroliceras occurrence in the Kenya-Madagascar-Kachchh area (Ethiopian Subprovince) is therefore in the basal Tithonian Hybonotum Zone, and this occurrence may extend to Nepal (Enay, 1973).

A significant member of this assemblage is Procraspedites cf. africanus (Zwierzicky), which is available in two specimens. The one comes from locality $8 \mathrm{f}$ at the top of the section, together with Hybonoticeras cf. hybonotum; the other specimen was found by geologists of the British Petroleum-Shell Development Company at locality 1781, close to our locality $8 \mathrm{e}$ (Text-fig. 2) and, because of the horizontal attitude of the beds, at a very similar stratigraphic level. This second specimen was identified by the distinguished late W.J. Arkell (in Eames and Clarke, 1964) with the early Cretaceous genus Groebericeras Leanza hitherto known only from Argentina. Consequently, the upper Changamwe Shales have been considered to be "Neocomian" in age (Walters and Linton, 1973). P. africanus is based on a single corroded specimen found loose by natives in the neighbourhood of the Smeei Bed of the Tendaguru Group in Tanzania (Zwierzicky, 1914; Janensch and Hennig, 1914). The similar Procraspedites mazapilensis occurs in Mexico in the Glochiceras fialar Zone of the middle Kimmeridgian, subjacent to the Hybonoticeras range zone, and thus approximately correlative to the Eudoxus Zone of Europe.

Pachysphinctes occurs throughout most of the section. It is based on $P$. africanus germanus (Dietrich, 1925) from the Kimmeridgian of Mahokondo near Tendaguru in Tanzania. We now believe $P$. germanus to be conspecific with $P$. beyrichi (Futterer, 1894) from equivalent beds of the Mombasa area.

The Phylloceratina account for approximately 20 per cent and the Lytoceratina for about 5 per cent of the total number of ammonoid specimens. Taxonomically, they closely resemble the faunas of the Hybonoticeras range zone of Madagascar and Kachchh. By far most abundant is Holcophylloceras polyolcum mesolcum (Dietrich) which occurs throughout the Hybonotum Zone and ranges downward at least into bed 8b. Dietrich's "species" from the (Lower) Kimmeridgian of Tanzania is here included in $H$. polyolcum (Benecke). According to Spath $(1933: 788,791)$, the restricted species occurs above $H$. p. mesolcum in the Katrol Group of Kachchh, but 
this is not borne out by our assemblages, nor by Spath's listing in the same volume (1933:708). Only H. mesolcum [aff. polyolcum (Benecke)] is listed from the "1st" and "2nd Katrol Assemblages", as well as from the Upper Tithonian ("Portlandian") Zamia Shales. Both "species" were identified by Collignon (1959) from the uppermost (Lower) Kimmeridgian "Zone of Aspidoceras longispinum and Torquatisphinctes alterneplicatus" of Madagascar.

Of the less common "Mediterranean" Phylloceratinae, Phylloceras isotypum Benecke has not been described from Kachchh or Madagascar; Calliphylloceras benacense (Catullo) is common in the " 1 st Katrol Assemblage" of Kachchh to which it was said to be restricted (Spath, 1933) and also occurs in the A. longispinum and $T$. alterneplicatus Zone of Madagascar (Collignon, 1959); Ptychophylloceras ptychoicum (Quenstedt), typically for the Tethyan Tithonian, is also common in the "1st" and "2nd Katrol Assemblages" of the Hybonoticeras range zone, and in the "'middle" and lower Upper Tithonian of Madagascar (incl. "P. tithonicum", Collignon, 1959, 1960).

Of the Lytoceratina, Lytoceras fraasi Dacqué [Hemilytoceras auct.] is apparently unknown outside of East Africa and of Madagascar where it occurs in the Upper Kimmeridgian (Collignon, 1959); while Pterolytoceras montanum (Oppel) is well known from the Mediterranean Lower to Upper Tithonian and, probably, occurs abundantly in the Kimmeridgian and lower Upper Tithonian of Manera on Madagascar (Collignon, 1960; cf. our synonymy).

\section{Lower Assemblage with Hybonoticeras pressulum}

This not very abundant assemblage occurs directly subjacent to the upper assemblage described above. It includes Aspidoceras (s. str.) spp. and the characteristic Hybonoticeras pressulum (Neumayr) in the middle and upper beds, and also Lithacoceras? mombassanum (Dacqué) in the lower and middle beds. The remainder of this assemblage is the same as in the upper assemblage. The small sample sizes may be responsible for the apparent absence of other taxa of the abundant upper assemblage, particularly since a number of them are known to range downward elsewhere (see above). This concerns particularly the basal $100 \mathrm{~m}$ of the section from which only Lithacoceras? mombassanum has been clearly identified, while the specific identifications of Aspidoceras acanthicum (Oppel) and A. iphicerum (Oppel) are uncertain. These basal shales with horizon $8 \mathrm{k}$ can therefore be placed only in the Kimmeridgian.

Approximately the upper $100 \mathrm{~m}$ (beds $8 \mathrm{~h}-8 \mathrm{~b}$ ) of this lower sequence can be dated with some confidence by the presence of Hybonoticeras pressulum (Neumayr). This species has not previously been identified from this biogeographic province, although Collignon's (1959) 'H. breistofferi', supposedly from the Hybonotum Zone of Madagascar, is closely similar. Throughout its geographic range in Europe (Spain to Bulgaria), however, $H$. pressulum is confined to the lower Beckeri Zone, that is, the Subeumela Subzone of Sapunov (1977; see also Berckhemer and Hölder, 1959; Enay and Geyssant, 1975; Barthel and Schairer, 1978). According to these authors, no Hybonoticeras is known from below the Beckeri Zone. Zeiss (1977, fig. 7) in Franconia, however, distinguishes the new zone of $H$. pressulum below the Beckeri Zone. We prefer to use the Beckeri Standard Zone in its broader sense and would include Zeiss's Pressulum Zone within the Beckeri Zone as a subzone. 
Interval $8 \mathrm{~h}-8 \mathrm{~b}$ is therefore placed in the Beckeri Standard Zone based on the presence of $H$. pressulum and its stratigraphic position subjacent to the Hybonotum Standard Zone. Other species, for example, Pachysphinctes beyrichi (Futterer), appear to range almost throughout the local section (see under Upper Assemblage).

\section{Ecology and Biogeography of Freretown Ammonoid Fauna}

\section{INTRODUCTION}

The worldwide differentiation of ammonoid fauna reached its peak in the late Jurassic as evidenced by the provinciality of a variety of organisms including belemnites, ammonites, brachiopods, foraminifera, gastropods, pelecypods, certain coelenterates, and calpionellids. The ammonites have proved to be useful tools not only in stratigraphic correlation but also in delineating the patterns of provinciality. Uhlig (1910) in his review of the works of Neumayr (1883, 1885), Nikitin (1886), and Haug (1907), distinguished four major realms. Subsequent authors recognized only three, the Boreal, the Tethyan, and the Pacific (Burckhardt, 1930; Arkell, 1956; Imlay, 1965) and, most recently, two major realms, the Boreal and the Tethyan, the latter including the Pacific Realm of other authors (Stevens, 1963b, 1965, 1967, 1971; Hallam, 1969a, 1969b, 1971; Enay, 1973, 1980). The subdivision of the realms into provinces has varied similarly. Thus Arkell's (1956) Tethyan Realm was composed of the Mediterranean, the Himalayan, the Maorian, and the Ethiopian provinces, whereas Stevens (1967) considered the Ethiopian and Indo-Pacific provinces as derivatives of the Tethyan Realm (s. str.); Enay (1973) formerly subdivided the Tethyan Realm into the Mediterranean, the Himalayan (or Indo-Pacific), and the Ethiopian provinces, but recently (1980) only into the Mediterranean and Indo-Southwest Pacific provinces, the latter including the Ethiopian Subprovince.

With the overwhelming acceptance of the plate-tectonic theory, recent authors (Stevens, 1967; Riccardi et al., 1971; Hallam, 1971; Enay, 1972; Verma and Westermann, 1973; Zeiss, 1974; Westermann, 1975; Westermann and Riccardi, 1976; Wiedmann, 1980) have projected their palaeontologic data on pre-drift reconstructions (particularly of Gondwanaland) of which several recent ones, based on geological and/or geophysical data, are presently available (e.g., Smith and Hallam, 1970; Dietz and Holden, 1970; Smith, 1971; Smith et al., 1973; Seyfert and Sirkin, 1973; Smith and Briden, 1977). Concerning Gondwanaland, these reconstructions differ mainly in the relative positions of Madagascar and the Indian subcontinent and in the timing of the plate movements. The most suitable reconstruction would be the one that offers the greatest compatibility among the geological, geophysical, and biogeographic data.

Enay (1972) has plotted the Tithonian faunistic data on a global reconstruction that was modified after Carey (1958) and resembles that of Smith (1971); this in turn is a combination of reconstructions by Bullard et al. (1965) and Smith and Hallam (1970). We agree with Enay that faunal realms should be viewed in the light of the actualistic palaeogeography taking into account the continental mobility. Enay (1972, 1980) distinguished during the Upper Jurassic the Boreal Realm ("Domaine Boréal"), the Tethyan Realm ("Domaine Téthysien"), and, beginning only in the 
late Tithonian, the Perigondwanian or Austral Realm ("Domaine Perigondwanien"). The Boreal Realm consists of the Boreal Province which includes the lands presently bordering the Arctic Ocean (arctic Canada, northern Siberia, the Petchora Basin, Spitzbergen, etc.) and the Subboreal Province including the southernmost margins of the Boreal region (with the subprovinces of the Canadian Cordillera, northwest Europe, and the eastern European Platform, distinguished as provinces by Donovan et al., 1981). The Tethyan Realm consists of the Mediterranean Province corresponding to the present Alpine chains of Europe and North Africa, and the Caribbean; the East-Pacific (or Andean s.l.) Province, south of the Canadian Cordillera; and of the Indo-Southwest Pacific Province. Only at the very end of the Jurassic or early in the Creteceous developed the Austral (or Perigondwanian) Realm across the old coastal lands of Gondwana and the seas of the Himalayan and south Andean regions (Enay, 1980). Enay (1972) thus rejects the so-called Pacific or Indo-Pacific Realm of Arkell (1956), Imlay (1965), Stevens (1963b, 1965, 1967, 1971), and Hallam (1971) on the grounds that this realm or province is indistinguishable when the geographic data are considered in the light of actual " mobilistic'" palaeogeography. The early Tithonian fauna of Kenya, thus, belongs to the Indo-Southwest Pacific Province of the Tethyan Realm. We will show that it contains a mixed fauna with strong affinities to Kachchh and Madagascar and with elements of the northern margin of the Mediterranean Province, that is, the Submediterranean Subprovince.

\section{ECOLOGY}

The late Kimmeridgian to early Tithonian macrofauna at Freretown consists almost entirely of Ammonoidea, with very scarce admixture of benthic shelly fauna. Among the ammonoids, the Ammonitina are prevalent ( 70 to $80 \%$ ), while the Phylloceratina (15 to $25 \%$ ) and Lytoceratina (5 to $10 \%$ ) make up the remainder. Among the Ammonitina, the typical perisphinctids (Perisphinctidae, Ataxioceratidae, and Aulacostephanidae; c. 30\%) are dominant and most diverse, followed closely by Aspidoceratidae (c. 20\%); the remainder consists of Oppeliidae (c. 10\%) and Simoceratidae (c. 5\%). Somewhat surprising when compared with European ammonite facies (Ziegler, 1967, 1971) and the occurrences at Mahokondo and Tendaguru in Tanzania (Zwierzicky, 1914; Dietrich, 1925, 1933) is the absence of the usually abundant Haplocerataceae Haploceras, Glochiceras, and Ochetoceras, this superfamily being represented only by Taramelliceras and Streblites. This and the near-absence of shelly benthic fauna may be due to the thick and pelitic facies with a high rate of detrital deposition, compared to the thinner and more strongly calcareous Submediterranean facies where Ziegler's scheme has been devised (and at Mahokondo). Caution is therefore indicated in attempting to infer the bathymetry of our faunal assemblages, in particular since the Phylloceratina and Lytoceratina may be allochthonous within these probable near-shore shelf deposits. The apparent bathymetric contradition concerns beds $8 \mathrm{~d}$ and $8 \mathrm{e}$ in which the probably shallow-water Gravesia-perisphinctid-Hybonoticeras assemblage (Zeiss, 1968) is associated with the deep-water phylloceratids and lytoceratids. This association somewhat resembles that of the underlying Middle Jurassic of the Kambe Limestone (Westermann, 1975). The dominant phylloceratids and lytoceratids were interpreted 
as having drifted onto the shelf from the open ocean after death.

We conclude very tentatively that the Ammonitina lived in a rapidly filling, outer shelf sea with depth varying perhaps between 50 and $200 \mathrm{~m}$, and that at least most of the Phylloceratina and Lytoceratina were oceanic and were transported postnecrotically onto this shelf.

\section{BIOGEOGRAPHY}

The affinities of both the upper and lower Freretown ammonite assemblages are clearly very close to the other parts of the Indo-Southwest Pacific Province; they belong to its Ethiopian Subprovince, together with the Madagascar and Kachchh occurrences. They are also equivalent to the incomplete fauna of the Smeei Group at Tendaguru in Tanzania.

The upper Freretown assemblage, placed in the Hybonotum Zone, is almost identical to the ammonite fauna of the Madagascan "Zone of $H$. hybonotum and Aspidoceras acanthicum" (placed in the Middle Kimmeridgian $s$. angl.) best developed at Manera, southwest Madagascar (Collignon, 1959). Besides the usual late Kimmeridgian to early Tithonian taxa Hybonoticeras, Katroliceras, Lithacoceras, Taramelliceras, Aspidoceras, and A. (Physodoceras), both the Kenyan and Madagascan assemblages have in common the relatively late occurrence of Streblites habyensis Spath, Aspidoceras cf. acanthicum (Oppel), and Pachysphinctes beyrichi (Futterer), as well as coarsely ribbed ?Subdichotomoceras. To this should probably be added the possible Madagascan occurrence of Gravesia (Collignon, 1960, fig. 647 of nucleus $\times 2$ !) in the supposed "Zone of Hildoglochiceras kobelli", at Marawoay. From the Manera occurrence of the same "zone", placed two zones above the " $H$. hybonotum and A. acanthicum Zone", however, Collignon (1959, 1964) also listed Hybonoticeras spp. and Aspidoceras (Physodoceras) avellanum Zittel. This indicates the Hybonotum Zone for at least part of this fauna, which is in need of more precise stratigraphic work. Collignon's $H$. hybonotum and $A$. acanthicum Zone, previously placed by us in the Beckeri Zone (Verma and Westermann, 1973, table 4), is now correlated with our upper Freretown assemblage and identified with the Hybonotum Standard Zone.

The "2nd Katrol Assemblage" from the red sandstones of the Middle Katrol Group of Kachchh (Spath, 1933) does correspond to the "Gravesia Zone" ( = Hybonotum Standard Zone) of Europe as suggested by Arkell (1956:388) and this is now verified by our new collections from Kenya. There are, however, fewer taxa in common between Kenya and Kachchh than between Kenya and Madagascar, particularly at the specific level, and these species are mostly also present in Madagascar, for example, Taramelliceras kachhense, Streblites habyensis, Katroliceras pottingeri, and Aspidoceras iphiceroides. Spath (1933:818), subsequent to his principal work on the Mombasa area (Spath, 1930), also identified from the "Coroa Mombasa" north of Freretown the Kachchh species Aspidoceras wynnei (Waagen), Pachysphinctes major Spath, and "P. habyensis"' Spath, and stated that "every ammonite known from the Middle Kimmeridgian of Mombasa . . . belongs to a familiar Kachchh species." These specimens, however, have not been figured (and the species " $P$. habyensis" has never been described?). On the other hand, such 
common Mediterranean Province taxa as Lithacoceras and Aspidoceras (Physodoceras) are very rare or absent in Kachchh but well represented in East Africa and Madagascar. The much closer affinity of the East African-Madagascan faunas to the northwestern Mediterranean Province (the Submediterranean Subprovince) is particularly evident at the species level, while the Kachchh species have supposedly a higher degree of endemicity - although this could be partly an artifact of Spath's taxonomic splitting.

The presence of the upper assemblage at other East African localities is possible but cannot yet be established because of a lack of stratigraphic work. This particularly concerns the rich ammonite faunas of Tanzania which at Tendaguru belong to the Lower Tithonian (Zwierzicky, 1914; Dietrich, 1925, 1933; Spath, 1933; Arkell, 1956) and are currently being reinvestigated by M.K. Howarth of the British Museum. The Smeei Group of Tendaguru consists of littoral, fluviatile, and lagoonal deposits, and is famous for its "Lower", "Middle", and "Upper Saurien Beds". Between these three levels are the littoral sandstones respectively of the "Nerineenschicht" or Nerinella Bed, below, and the Smeei Bed, above (Dietrich, 1933). Dietrich has already pointed out that the total time span may be short and the very scarce ammonite fauna of the Smeei Bed may be identical with the slightly richer one of the Nerinella Bed. The stratigraphic record of the ammonite species is, however, poorer than is apparent from the palaeontologic description (cf. Janensch and Hennig, 1914). The fauna includes Subdichotomoceras? cf. sparsiplicatum (Waagen), Procraspedites africanus (Zwierzicky), and ?Pachysphinctes beyrichi (Futterer) (cf. Dietrich, 1933, pl. 1, fig. 1), but also Haploceras and Hildoglochiceras, probably due to difference in biofacies.

A facies like the Changamwe Shale with concretions containing Kimmeridgian ammonites is developed in the Mahokondo area, Tanzania, but additional work with stratigraphic detail is necessary.

To the north, the poorly known basal Tithonian is almost certainly present in Somalia in the lower Gawan Limestone or upper Daghani Shales, above the Kimmeridgian beds containing Hybonoticeras and Idoceras spp. (cf. Arkell, 1956:308-9). Again, detailed work is needed. Good evidence for basal Tithonian exists for Ethiopia where Hybonoticeras appears to be associated with Subplanites: larger assemblages need to be collected (Dacqué, 1914; Arkell, 1956:315).

The most significant new findings of Mombasa, however, are the elements in common with Kurdistan in Iraq, that is, Phanerostephanus (Nothostephanus), and with Submediterranean to Subboreal northwestern Europe (and ?the Boreal basal Volgian fauna of the Russian platform and western Siberia), that is, Gravesia.

The lower Freretown assemblage is insufficiently known because of its relative scarcity and often uncertain specific identity (cf. Table 2). However, its general character is certainly also close to the Madagascan equivalent, that is, the "Zone of Aspidoceras longispinum and Torquatisphinctes alterneplicatus"' (Collignon, 1959); as well as to Spath's (1933) "1st assemblage" from the basal Katrol Group of Kachchh, India, and probably also to the ill-defined, much more poorly known faunas, containing the first Hybonoticeras sp., of Ethiopia and Somalia to Tanzania (cf. Arkell, 1956). The first clear evidence of Hybonoticeras pressulum at Freretown, however, not only permits correlation with the Beckeri zone but also indicates again the Mediterranean connections of the East African faunas. 


\section{Systematics}

The majority of the ammonite taxa encountered by us in the Changamwe Shale of the Freretown area are already known through the works of Beyrich $(1877,1878)$, Futterer (1894), Dacqué (1910), and Spath (1930a). The descriptions that follow pertain mainly to those that have not been reported from Kenya before and to two new species. The new material of the species known previously is recorded and the taxonomy revised where necessary. A few specimens better preserved than those figured before are illustrated.

Suborder Phylloceratina Arkell, 1950

Family Phylloceratidae Zittel, 1884

Subfamily Phylloceratinae Zittel, 1884

Genus Phylloceras Suess, 1865

\section{Type Species}

Ammonites heterophyllus J. Sowerby, 1820.

\section{Phylloceras isotypum Benecke, 1865}

Pl. 1, figs. 1a-c

For synonymy see Spath, 1930a:20-21.

\section{New Material}

Three specimens: KNMI-MA23, undistorted phragmocone with part of shell preserved; from loc. 4 (=8a). ROM 34540, septate internal mould, weathered, with septal sutures throughout; and ROM 34541, incomplete, and weathered on one side; from loc. 8d.

\section{Remarks}

Our specimens are identical to the one figured by Spath (1930a, pl. 1, fig. 1). KNMI-MA23 is thinner at the same diameter than ROM 34540 but the difference is considered infraspecific. KNMI-MA23 clearly shows the fine, slightly sigmoidal ribs. $P$. subplicatus Burckhardt (1912:40, pl. 7, figs. 1-6) and $P$. appenninicum Canavari (in Burckhardt, 1906:106, pl. 28, figs. 1-5) from the Lower Tithonian of Mexico have in addition conspicuous radial folds.

\section{Stratigraphic Occurrence}

Hybonotum Zone.

\section{Measurements}

$\begin{array}{lcccccc}\text { SPECIMEN NO. } & \mathrm{D} & \mathrm{U} & \mathrm{U} / \mathrm{D} \% & \mathrm{H} & \mathrm{W} & \mathrm{H} / \mathrm{W} \\ \text { KNMI-MA23 } & 78.0 & \text { c } .3 .0 & 3.8 & 46.0 & 24.0 & 1.91 \\ \text { ROM } 34540 & 88.0 & \text { c } .5 .0 & 5.6 & 47.0 & 31.0 & 1.51\end{array}$


Subfamily Calliphylloceratinae Spath, 1927

Genus Calliphylloceras Spath, 1927

Type Species

Phylloceras disputabile Zittel, 1869.

\section{Calliphylloceras benacense (Catullo, 1847)}

Pl. 1, fig. 2

Ammonites benacensis Catullo, 1847:9, pl. 12, fig. 1.

Phylloceras benacense - Neumayr, 1871:336, pl. 15, fig. 3; Waagen, 1875:33, pl.

5, figs. 3a-c.

Phylloceras malayanum - Dacqué, 1910:6, pl. 1, figs. 1-3.

Calliphylloceras cf. benacense - Spath, 1927:55, pl. 7, figs. 4a, b.

Calliphylloceras aff. benacense - Spath, 1930a:23.

Calliphylloceras benacense - Collignon, 1959, pl. 97, fig. 368.

\section{New Material}

Four specimens, all internal moulds of phragmocones. KNMI-MA24, well preserved with constriction and septal sutures; ROM 34543, small, incomplete; ROM 34544, juvenile embedded in rock; all from loc. 8c. ROM 34542, with part of test, from loc. 8 h.

\section{Description}

The phragmocone is medium large ( $D \simeq 67 \mathrm{~mm}$ ), compressed, and highly involute. The umbilicus is deep with convex, almost vertical wall, and is approximately 8 to 13 per cent of the diameter. The flank is nearly flat and the venter broadly arched. Flanks and venter are traversed by equally spaced, moderately deep, slightly sigmoidal constrictions, about four to six on each whorl. The test shows fine prorsiradiate striations covering the flank and venter. The septal suture is identical to the one figured by Waagen (1875, pl. 5, fig. 3c) and consists of a tetraphyllic external saddle, a pentaphyllic lateral saddle, and five mostly diphyllic lobes.

\section{Remarks}

Dacqué (1910) identified his Mombasa specimens with the Oxfordian C. malayanum Boehm from Indonesia. However, that species is thicker, larger, and has more sigmoidal constrictions. Spath (1930a) correctly compared his fragmentary specimens from the Changamwe Peninsula with Catullo's species but did not illustrate any of them.

\section{Stratigraphic Occurrence}

Mainly middle part of Hybonotum Zone, but also in the Kimmeridgian. 


\section{Measurements}

$\begin{array}{lcrrrrr}\text { SPECIMEN NO. } & \mathrm{D} & \mathrm{U} & \mathrm{U} / \mathrm{D} \% & \mathrm{H} & \mathrm{W} & \mathrm{H} / \mathrm{W} \\ \text { ROM } 34542 & 67.0 & 6.0 & 8.9 & 37.0 & 24.0 & 1.54 \\ \text { KNMI-MA24 } & 53.5 & 6.0 & 11.0 & 29.0 & 19.5 & 1.48 \\ & 61.0 & \text { c } .5 .0 & 8.1 & 34.0 & 23.0 & 1.47 \\ \text { ROM } 34543 & 40.0 & \text { c } .5 .0 & 12.5 & \text { c. } 20.0 & - & - \\ \text { ROM } 34544 & \text { c. } 29.0 & \text { c. } 4.0 & 13.7 & 15.5 & - & -\end{array}$

Calliphylloceras aff. C. malayanum (Boehm, 1907)

Pl. 1, figs. 3a-c

?Phylloceras malayanum Boehm, 1907:78, pl. 12, figs. 7a, b; pls. 13-15, figs. 1, 2; text-figs. 24-26.

\section{Material}

One incomplete phragmocone, KNMI-MA25; from loc. $8 \mathrm{~b}$.

\section{Description}

This is a giant species; our specimen is still septate at a diameter of about $280 \mathrm{~mm}$. The shell is compressed and obvolute (occluded umbilicus) with gently curved flanks and highly arched venter. The flank carries broad, very shallow, slightly sigmoidal constrictions. The test appears to be devoid of striations. The phylloid suture line is similar to the ones illustrated by Boehm (1907, figs. 24-26).

\section{Remarks}

In its giant size and the nature of the constriction and the septal suture, our specimen can be best related to Boehm's Indonesian species. Our specimen, however, does not reveal the fine striations so well illustrated by Boehm. The "Phylloceras malayanum" of Dacque (1910) is placed in C. benacense (Catullo). This is the first giant Calliphylloceras obtained from Mombasa.

\section{Stratigraphic Occurrence}

Beckeri Zone.

\section{Measurements}

SPECIMEN NO.

KNMI-MA25

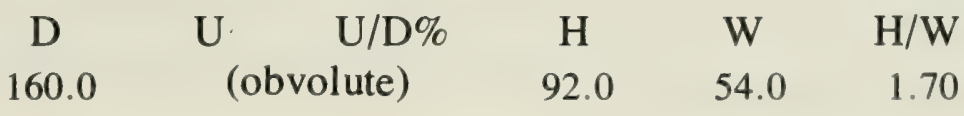

Genus Ptychophylloceras Spath, 1927

\section{Type Species}

Phylloceras feddeni Waagen, 1875.

Ptychophylloceras ptychoicum (Quenstedt, 1845)

Pl. 2, figs. 1a, b 
Ammonites ptychoicus Quenstedt, in Leonhardt and Brown, 1845:683; 1847:219, pl. 17, fig. 12 [fide Waagen, 1875].

Phylloceras ptychoicum-Waagen, 1875:30, pl. VII, figs. 2a-c.

Phylloceras subptychoicum Dacqué, 1910:7, figs. 1a, b.

Ptychophylloceras subptychoicum-Spath, 1927:46; Spath, 1930a:24, pl. 1, fig. 7.

Ptychophylloceras ptychoicum-Arkell, in Linton and Maclean, 1955.

Ptychophylloceras aff. ptychoicum-Collignon, 1959:148, fig. 371.

Ptychophylloceras tithonium - Collignon, 1960:138, figs. 527, 528.

\section{New Material}

Eleven phragmocones in various states of preservation and completeness. ROM 34546, well preserved; ROM 34547, incomplete; ROM 34548, fragment; and KNMI-MA26, fragment; all from loc. 8d. ROM 34549, septate fragment; and ROM 34550 , septate fragment embedded in concretion; from loc. $8 \mathrm{j}$. ROM 34551 , well preserved; ROM 34552, incomplete; ROM 34553, fragment; ROM 34554, well preserved, embedded in concretion, and ROM 34555, phragmocone with test preserved; all from loc. $15 \mathrm{c}$ at Port Reitz.

The British Petroleum-Shell Development Company collection made by R.G. Maclean at the "east shore of Port Tudor, 2.75 miles northeast of Changamwe Station and 2 miles northwest of junction of tract of Nguu Tatu with main coast road", contains two specimens (ROM 34602, RGM 1889); one of them (ROM 34602) includes the body chamber which has been missing in all specimens previously figured.

\section{Remarks}

The large specimen (ROM 34602) figured shows several weak ventral flares on the body chamber. The venter of this specimen has, however, been crushed, destroying much of the structures.

P. subptychoicum (Dacqué) was described in detail by Dacqué (1910) and Spath (1930a). Spath believed that it differed from Ptychophylloceras ptychoicum (Quenstedt) in the less developed tetraphyllic subdivision of the terminal leaflets of the principal saddles and in the projecting leaflet on the umbilical side of the external saddle resulting in asymmetry. All specimens available to us show this remarkable feature. The larger of the two specimens (ROM 34602) and our specimens ROM 34554 and ROM 34555 have about one-quarter whorl of the body chamber showing a partial "umbilical rosette" (comma-shaped grooves on the inner portion of the flanks). However, these features occur also in true $P$. ptychoicum so that $P$. subptychoicum is synonymized with it.

\section{Stratigraphic Occurrence}

Beckeri and Hybonotum Zones.

\section{Measurements}

$\begin{array}{lllcccc}\text { SPECIMEN NO. } & \text { D } & \text { U } & \text { U/D } \% & \text { H } & \text { W } & \text { H/W } \\ \text { ROM } 34546 & 76.0 & \text { c. } 2.0 & 2.6 & 42.0 & 38.0 & 1.10 \\ \text { ROM } 34551 & \text { c. } 80.0 & \text { c. } 3.0 & 3.7 & 45.0 & \text { c. } 35.0 & 1.28 \\ \text { ROM } 34554 & 25.0 & \text { c. } 1.0 & 2.8 & 20.0 & 18.0 & 1.11 \\ \text { ROM } 34555 & 57.0 & \text { c. } 2.0 & 3.5 & 31.0 & 26.0 & 1.19 \\ \text { ROM } 34602 & 74.0 & \text { c. } 2.0 & 2.7 & 46.0 & 38.0 & 1.21\end{array}$


Genus Holcophylloceras Spath, 1927

\section{Type Species}

Phylloceras mediterraneum Neumayr, 1871.

\section{Holcophylloceras polyolcum mesolcum (Dietrich, 1925)}

Phylloceras mesolcum Dietrich, 1925:8, pl. 1, figs. 4, 5.

Holcophylloceras mesolcum-Collignon, 1959:96, fig. 366.

Holcophylloceras polyolcum-Collignon, 1959:97, fig. 367.

For complete synonymy see Spath, 1927:60 and 1930a:24.

\section{New Material}

Sixteen specimens, all but three are well-preserved internal moulds of phragmocones, some with test preserved. KNMI-MA27, well-preserved phragmocone with crushed body chamber, ROM 34556, crushed phragmocone; from loc. 8a. ROM 34557, phragmocone with test showing ribs; and ROM 34558, septate fragment of a very large specimen; from loc. 8b. ROM 34560, well-preserved large phragmocone; ROM 34561, septate fragment; ROM 34562, small internal mould of phragmocone; ROM 34563, small fragment; ROM 34564, small phragmocone; ROM 34565, phragmocone with ? body chamber; ROM 34559, phragmocone embedded in concretion; and ROM 34569 , badly weathered phragmocone; from loc. 8d. ROM 34566, small phragmocone weathered on one side; ROM 34567, largest specimen in the collection, phragmocone showing the beginning of the body chamber; ROM 34568, incomplete phragmocone; and ROM 34570, phragmocone crushed on one side; from loc. 8e.

\section{Remarks}

The subspecies is well known and was adequately illustrated by Dietrich (1925) from Tanzania and by Spath $(1927,1930 a)$, from Mombasa, as well as from Kachchh, where it occurs in profusion in the lower and middle Katrol Beds. According to Dietrich and Spath, $H$. mesolcum is connected by transitions to the associated $H$. polyolcum (Benecke, 1865:182, pl. VII) which has slightly more numerous constrictions, but they may have different stratigraphic ranges (Spath, 1931:788, 791). We therefore distinguish both at the subspecies level only. H. mediterraneum, also known from the Callovian of Kachchh, is smaller and has fewer (7 to 9) sigmoidal rursiradiate constrictions than the present form (10 to 13); but immature specimens have an identical number of constrictions.

\section{Stratigraphic Occurrence}

Beckeri and Hybonotum Zones. 
Measurements

\begin{tabular}{lrrrrrr} 
SPECIMEN NO. & \multicolumn{1}{c}{$\mathrm{D}$} & \multicolumn{1}{c}{$\mathrm{U}$} & $\mathrm{U} / \mathrm{D} \%$ & $\mathrm{H}$ & $\mathrm{W}$ & $\mathrm{H} / \mathrm{W}$ \\
ROM 34557 & 72.5 & c. 8.0 & 11.0 & 39.0 & 23.5 & 1.65 \\
KNMI-MA27 & 97.0 & 9.5 & 9.7 & 52.5 & 32.0 & 1.64 \\
ROM 34560 & 140.0 & 15.0 & 10.7 & 78.0 & c. 47.0 & 1.65 \\
ROM 34562 & 98.0 & 13.0 & 13.2 & 52.0 & c. 28.0 & 1.85 \\
ROM 34564 & 86.0 & 9.5 & 11.0 & 47.0 & 29.0 & 1.65 \\
ROM 34565 & 68.0 & c. 10.0 & 14.7 & 37.0 & 21.5 & 1.72 \\
ROM 34566 & 82.5 & 11.0 & 13.3 & 43.5 & 23.5 & 1.85 \\
ROM 34567 & 167.0 & 15.0 & 8.9 & 95.0 & 58.5 & 1.62 \\
ROM 34568 & 90.0 & c. 9.0 & 10.0 & 45.0 & 29.0 & 1.55
\end{tabular}

Suborder Lytoceratina Hyatt, 1889

Family Lytoceratidae Neumayr, 1875

Subfamily Lytoceratinae Neumayr, 1875

Genus Lytoceras Suess, 1865

Type Species

Ammonites fimbriatus J. Sowerby, 1817.

Lytoceras fraasi Dacqué, 1910

Pl. 2, fig. 2

Lytoceras fraasi Dacqué, 1910:1, pl. 1, figs. 4a-c.

?Hemilytoceras fraasi-Collignon, 1959, fig. 369.

\section{New Material}

Six specimens of which three are phragmocones with attached body chambers. ROM 34571 , undistorted phragmocone with partial body chamber; ROM 34572, fragmentary phragmocone; from loc. 8d. KNMI-MA28, phragmocone with body chamber inner whorls missing; and ROM 34574, laterally compressed septate fragment; from loc. 15 b. ROM 34573 , body chamber with a part of the phragmocone preserved; and ROM 34575 , septate fragment; from loc. $15 \mathrm{c}$.

\section{Remarks}

This species, described and illustrated by Dacqué (1910) and Spath (1930a), appears to have been based on smooth inner phragmocone whorls with little test preserved. Although separate fragments of body chambers existed in earlier collections, the assignment to Hemilytoceras by Spath (1930a) was not substantiated. The high lamellae said to be typical for Hemilytoceras are absent in the Mombasa material. The sculpture consists of fine striations and the expansion rate of the whorls is moderate as 
in Lytoceras. Pterolytoceras is serpenticonic and has blunt ribs on the body chamber. The whorl section in all our specimens is nearly circular. It is possible that the small specimens of Dacqué (1910) and Spath (1930a) are inner whorls of Pterolytoceras montanum (Oppel) which is also present at Mombasa (see below). Collignon, (1959, pl. 97, fig. 369) figured a similar specimen from Madagascar.

\section{Stratigraphic Occurrence}

Beckeri and Hybonotum Zones.

\section{Measurements}

$\begin{array}{lcccccc}\text { SPECIMEN NO. } & \mathrm{D} & \mathrm{U} & \mathrm{U} / \mathrm{D} \% & \mathrm{H} & \mathrm{W} & \mathrm{H} / \mathrm{W} \\ \text { ROM 34571 phragm. } & 128.0 & 60.0 & 46.8 & 43.0 & 44.0 & 0.97 \\ \text { KNMI-MA28 body ch. } & 125.0 & 49.0 & 39.2 & 39.0 & 35.0 & 1.11\end{array}$

Genus Pterolytoceras Spath, 1927

\section{Type Species}

Ammonites exoticus Oppel, 1863.

\section{Pterolytoceras montanum (Oppel, 1865) \\ Pl. 2, figs. 3a, b}

Ammonites montanus Oppel, 1865:551.

Lytoceras montanum-Zittel, 1870:45, pl. XXVI, figs. 3, 4.

Ammonites cf. rex.-Beyrich, 1877:99.

Lytoceras cf. montanum-Futterer, 1894:12, pl. 3, figs. 3, 3a, 3 b.

Lytoceras cfr. rex.-Dacqué, 1910:9.

Hemilytoceras cf. montanum-Spath, 1927:70, pl. VI, fig. 3; Spath, 1930a:27.

?Pterolytoceras sutile Oppel var. Madagascariensis Collignon, 1960, pl. XXXIX, figs. 529, 530: pl. CXL, fig. 529b.

?Pterolytoceras exoticum-Collignon, 1960, pl. CXL, figs. 532, 533.

?Pterolytoceras sikilyense-Collignon, 1960, pl. CXLI, fig. 534.

?Pterolytoceras reamilitzyense - Collignon, 1960, pl. CXLI, fig. 535.

\section{New Material}

Three specimens. ROM 34576, undistorted phragmocone with partial test; from loc. 4 . ROM 31577, partial body chamber with test; and KNMI-MA29, external mould with protoconch and part of the internal mould of crushed body chamber; from loc. $8 \mathrm{~d}$.

\section{Remarks}

Beyrich (1877) placed this species in the similarly large Hemilytoceras rex (Waagen), but Futterer's illustration shows that Beyrich's specimen is an inner phragmocone whorl similar to our specimen ROM 34576. The species is said tọ be present in Spath's 
material as impression on a matrix of a lamellose aptychus. All our specimens show the crinkled lamellae on the test also known from Pterolytoceras sutile (Oppel), $P$. rex (Waagen), and $P$. eudesianum (d'Orb.). The several supposed species figured by Collignon (1960) from Madagascar appear to be at different stages of growth and to exhibit different degrees of completeness. The largest of the three specimens in our collection is figured here.

\title{
Stratigraphic Occurrence
}

Hybotonum Zone.

\section{Measurements}

$\begin{array}{lcccccc}\text { SPECIMEN NO. } & \text { D } & \text { U } & \text { U/D } \% & \text { H } & \text { W } & \text { H/W } \\ \text { ROM 34576 phragm. } & 58.0 & 26.5 & 46 & 20.0 & 17.5 & 1.17\end{array}$

Suborder Ammonitina Hyatt, 1889

Superfamily Haplocerataceae Zittel, 1884

Family Oppeliidae Douvillé, 1890

Subfamily Taramelliceratinae Spath, 1928

Genus Taramelliceras Del Campana, 1904

(Nom. nov. for Neumayria Bayle, 1878 non De Stefani, 1877)

\section{Type Species}

Ammonites trachinotus Oppel, 1863; subseq. des. H. Douvillé, 1879.

\section{Taramelliceras (Taramelliceras) cf. T. kachhense (Waagen, 1875)}

\author{
P1. 3, figs. 1a, b
}

?Oppelia kachhensis Waagen, 1875:55, pl. X, figs. 4, 4a, 4c.

TTaramelliceras kachhense-Spath, 1928:134, pl. VIII, figs. 2a, b, 4; pl. XIV, figs. $6,12,13$; pl. XVII, figs. 3a, b; pl. XVIII, figs. 1a, b, 6.

?Taramelliceras kachhense Spath var. belamboensis Collignon, 1959, pl. CXII, figs. 415-17.

\section{Material}

Three specimens. KNMI-MA30, phragmocone and body chamber well preserved on one side; and ROM 34849, incomplete phragmocone; from loc. 8d. ROM 34850 , septate fragment; from loc. $15 \mathrm{c}$.

\section{Description}

The shell is discoidal, involute. The narrow umbilicus is shallow with a steep, almost vertical umbilical wall. The flanks are almost flat and the venter narrowly rounded. The flanks are covered by flexuous ribs many of which terminate at the latero-ventral shoulder in thick clavi. The phragmocone has a diameter of about $95 \mathrm{~mm}$ and the ribs as well as the tubercles appear to become less prominent on the body whorl. The mid-ventral tubercles are not clearly visible on the outer whorls of the larger, more complete specimen KNMI-MA30, but are clearly evident on the septate fragment ROM 34850 and the phragmocone ROM 34849. 


\section{Remarks}

The species is abundant in the Beckeri Zone (basal Katrol Group) of Kachchh and in the Hybonotum Zone of Madagascar. Our new material, although scarce and of modest preservation, indicates the existence of this or a nearly allied species in Kenya. In Waagen's species the shell becomes smooth at about $55 \mathrm{~mm}$ diameter, whereas our material shows that the ribs and ventro-lateral clavi continue on the body chamber up to a diameter of about $105 \mathrm{~mm}$. The mid-ventral tubercles are seen in Waagen's examples only in the young specimens. Paucity of material and poor preservation prevent us from confidently establishing identity with Waagen's species.

\section{Stratigraphic Occurrence}

Mainly Hybonotum Zone.

\section{Measurements}

$\begin{array}{lcccccc}\text { SPECIMEN NO. } & \mathrm{D} & \mathrm{U} & \mathrm{U} / \mathrm{D} \% & \mathrm{H} & \mathrm{W} & \mathrm{H} / \mathrm{W} \\ \text { KNMI-MA30 } & 118.0 & 19.5 & 16.5 & 62.0 & \mathrm{c} .30 .0 & 2.06\end{array}$

Taramelliceras (Taramelliceras) trachynotum (Oppel, 1862)?

Pl. 3, figs. 2a, b

?Ammonites trachynotus Oppel, 1862:214, pl. 56, fig. 4; Beyrich, 1878:771.

Oppelia trachynota-Futterer, 1894:13.

?Oppelia (Neumayria) trachynota-Dacqué, 1910:9, pl. III, fig. 5.

?Taramelliceras cf. trachinotum-Spath, 1930a:30, pl. II, fig. 6.

\section{New Material}

One or two specimens, fragments of body chamber. ROM 34579, from loc. 8j. ?KNMI-MA31, from loc. $8 \mathrm{~h}$.

\section{Remarks}

Although the existence in the Mombasa area of this well-known European species was indicated previously (Beyrich, 1878; Futterer, 1894; Dacqué, 1910; Spath, 1930a), all collections including our own have yielded only fragmentary material. Our specimens show the characteristic features of this species including the lateral clavi and mid-ventral serrations. However, the flexuous ribs appear to have been obliterated by crushing.

\section{Stratigraphic Occurrence}

Beckeri Zone. 
Genus Streblites Hyatt, 1910

\section{Type Species}

Ammonites tenuilobatus Oppel, 1862.

\section{Streblites habyensis Spath, 1928}

Pl. 3, figs. 3a-d

Streblites habyensis Spath, 1928:151, pl. VIII, fig. 1; Collignon, 1959, pl. CXI, fig. 411.

?Streblites plicodiscus - Collignon, 1959, pl. CXI, figs. 409, 410 [nom. dub.?]. ?Streblites percostatus Collignon, 1959, pl. CXI, fig. 413.

\section{Material}

Seven specimens. ROM 34581, distorted specimen embedded in concretion; from loc. 8c. ROM 34582, incomplete specimen embedded in concretion; KNMI-MA32, complete specimen with partially crushed body chamber; ROM 34584 , body chamber with mould of phragmocone embedded in concretion; from loc. 8d. ROM 34585, inner part of phragmocone; from loc. 15a; KNMI-MA33, KNMI-MA34, one small phragmocone and one large complete specimen, both embedded in concretion; Mto Panga Quarry area.

\section{Description}

The shell is typically oxyconic with a narrow umbilicus. In undistorted specimens the whorl flanks gradually slope towards the venter which is sharply rounded. The falcoid primary ribs on the flanks are clearly visible on the better-preserved parts of specimens or on the internal moulds. The same is true for the secondary ribs which appear at about two-thirds whorl height. In better-preserved specimens a shallow spiral furrow traverses the middle of the whorl sides. The suture, typical of the genus, consists of a wide median saddle, a wide and deep (first) lateral saddle, and four or five umbilical lobes of diminishing depth.

\section{Remarks}

This species, previously known only from the lower and ?Middle ["plicodiscus"'] Katrol Group of Kachchh and the Hybonotum Zone of Madagascar, is recorded here from Kenya for the first time. In general shape, our specimens are indentical to the ones figured by Spath from Kachchh and by Collignon from Madagascar. The septal suture, however, is simpler possibly due to weathering. (Note that "Pseudoppelia" Leanza, 1946, erroneously described from the Kimmeridgian and with simple suture, is a weathered Callovian Oxycerites.) Streblites plicodiscus (Waagen, 1875:56, pl. $\mathrm{X}$, figs. $5 \mathrm{a}, \mathrm{b}$ ) is probably an allied species but is poorly known (based on a single nucleus). 


\section{Stratigraphic Occurrence}

Hybonotum Zone.

\section{Measurements (better preserved specimens only)}

$\begin{array}{lrrrrrc}\text { SPECIMEN NO. } & \mathrm{D} & \mathrm{U} & \mathrm{U} / \mathrm{D} \% & \mathrm{H} & \mathrm{W} & \mathrm{H} / \mathrm{W} \\ \text { ROM } 34582 & 76.0 & \text { c. } 7.0 & 9.2 & \text { c. } 39.0 & \text { c. } 10.0 & 3.9 \\ \text { KNMI-MA32 } & 76.0 & \text { c. } 5.0 & 6.5 & 41.0 & \text { c. } 15.0 & 2.73 \\ \text { ROM } 34584 & 73.0 & \text { c. } 8.0 & 10.9 & 39.0 & - & - \\ \text { ROM } 34585 & 27.0 & 7.4 & 16.5 & 16.5 & \text { c. } 8.5 & 1.94 \\ \begin{array}{l}\text { KNMI-MA33 } \\ \quad \text { phragm. }\end{array} & 43.5 & 4.0 & 9.1 & 23.5 & - & - \\ \text { KNMI-MA34 body ch. } & 118.0 & 11.5 & 9.7 & 66.0 & \text { c. } 12.0 & 5.5\end{array}$

Superfamily Perisphinctaceae Steinmann, 1890

Family Perisphinctidae Steinmann, 1890

Subfamily Perisphinctinae Steinmann, 1890

\section{Genus Pachysphinctes Dietrich, 1925}

\section{Type Species}

Perisphinctes (Pachysphinctes) africogermanus Dietrich, 1925 (by subsequent designation of Spath, 1931:467).

\section{Lectotype}

Here designated: original to Dietrich's pl. 1, fig. 2 (copied in Arkell et al., 1957, fig. $427,1 \mathrm{a} ; 1 \mathrm{~b}$ redrawn with altered final section).

One of us (Westermann) has re-examined the type sets (autohyle) in the Museum für Naturkunde der Humboldt-Universität, East Berlin (courtesy of Dr. H. Jaeger who also supplied photographs), and came to the following conclusion. Among the several dozens of specimens in the type set from Mahokondo, Tanzania, are only a very few (including the smaller specimen figured by Dietrich) with "rounded broad whorls and deep umbilicus" to about 40 to $50 \mathrm{~mm}$ diameter, characteristic features of this species according to the original description. The large majority of the specimens (including the large specimen figured by Dietrich) have narrower inner whorls (depressed in nucleus only?) and a shallow-subconical umbilicus (and somewhat denser primaries, c. 25 , vs. c. 20 per half-whorl). The best specimen according with the original description is designated the lectotype, that is, the medium-large original to Dietrich's pl. 1, fig. 2 (copied by Arkell et al., 1957, p. L328, fig. 427, 1a, b). Dietrich's whorl sections do not belong to the lectotype, but were probably taken from unidentified " $P$. africanus".

The lectotype and all other specimens are, however, incomplete and strongly 
distorted by "septarization" (diagenetic shrinkage in septarian concretions), with shell displacement from the internal mould, subsequent calcitic infillings, etc., all contributing to the difficulties in reconstructing the original shell.

The type species is thus characterized by depressed, rounded, ovate, immature whorls and very prominent biplicate ribbing with long primaries becoming ataxiocerid on the outer whorl.

The more complete, larger paralectotype (Dietrich, 1925, pl. 3, fig. 1) and the majority of the type set are perhaps identical with "Perisphinctes africanus" Dacqué, 1910, based on an incomplete septate specimen. Most specimens of the $P$. africogermanus set, in fact, had been so labelled and Dietrich had realized the possible synonymy of his new name. He disregarded (?correctly), however, Dacqué's name as a nomen dubium, having been based on unsatisfactory material without preservation of the important mature whorls. These specimens have also rather frequent simple ribs.

Only accurate re-collecting at the type locality can establish the significance of the mentioned difference in the inner whorl and the affinities of " $P$. africanus".

$P$. beyrichi (Futterer, 1898), described below, resembles the probable " $P$. africanus" discussed above, differing only in the somewhat more compressed mature whorls. We are using this name since it has seniority and was established on good type material.

\section{Comparison}

A closely related genus is Katroliceras Spath, 1924, distinguished mainly in the body chamber with widely spaced, very prominent bullate primaries and four or five irregular secondaries per primary. The separation of these supposed genera, however, remains dubious, since species with similar but regular Perisphinctes-like multiple secondaries also occur, for example, "Perisphinctes torquatus Waagen, (non Sowerby)" =Pachysphinctes major Spath; as well as forms with finer secondaries and rather coarse primaries which Spath places in Katroliceras, for example, " $K$." arenosum Spath (and even in Subplanites, for example, S. adeloides Spath). Both of Waagen's species, 'Perisphinctes"' katrolense and ' $P$.'" bathyplocus, are difficult to place and one has only to study Spath's (1931) monograph on Kachchh (e.g., pl. 100 , figs. $1 \mathrm{a}, \mathrm{b})$ to realize that even he admittedly could not clearly discriminate between many of the genera of his own creation. As usual he accompanied genus-level splitting with species-level splitting, and the necessary taxonomic revision of this extensive fauna will be most difficult.

The compressed, coarsely ornate forms of Katroliceras and Pachysphinctes are also hard to separate from Subdichotomoceras, particularly in the microconchs of the former two where the coarse biplicate ribbing typical for the latter may continue almost to the aperture (many examples in Spath, 1931; see under K.? aff. bathyplocus). We have considered relatively short primaries and coarse ornament of the inner whorls as distinguishing characteristics for Subdichotomoceras in this case. It should be remembered, however, that the type species of this genus is from Boreal central to northern England and the Tethyan form may be a homeomorph allied to the Pachysphinctes-Katroliceras group. This comes to mind when studying the co-occurring $P$. beyrichi and $S$.? cf. sparsiplicatum from Mombasa. This problem can only be solved with excellent material from both faunal realms at hand. Originally, we placed Pachysphinctes as a subgenus in Katroliceras, but we have 
again separated them generically because of the very marked differences of the type species at maturity. Again, a thorough re-examination of the entire species complex is needed.

Another, apparently related, poorly known and often misinterpreted taxon is Torquatisphinctes Spath, 1924. The type species, Ammonites torquatus J. de C. Sowerby (1840), is based on a rather poorly preserved, small, and incomplete holotype (refigured by Spath, 1931, pl. 76, figs. 4a,b) which may be either an inner whorl of a much larger macroconch or an almost complete microconch. The typically planulate shell has subquadrate whorls bearing dense ribbing which is distinctive in the presence of abundant simple ribs. Dr. Jai Krishna (pers. comm.) has collected what he considers to be topotypes from the Kimmeridgian of Jaiselmer in Rajasthan. The incomplete small specimens of modest preservation all show the densely ribbed subquadratic whorls with abundant simple ribs, differing markedly from Katroliceras and other similar coarsely ribbed forms. Torquatisphinctes, however, remains poorly known so that the generic name should be used only with extreme caution.

Another genus, well known from its type locality at Niti in the Himalayas, and probably more widely distributed than is apparent from the descriptions, is Aulacosphinctoides Spath, 1924. The type species, Aulacosphinctes infundibulus Uhlig (1910), as well as a host of similar and probably intergrading "species", are characterized by depressed elliptical to ovate whorls with mostly dichotomous dense sigmoid ribbing, often followed by a triplicate and/or ataxiocerid adult stage with stiffer primaries. Thus, it is distinguished from Pachysphinctes by the more inflated whorls and, typically, by the more sigmoid ribbing, but the distinction becomes spurious with intermediate forms and both are certainly closely related.

We retain these taxa at the generic level only because we are unable to solve the taxonomic problems at the genus-group level without re-examining all the type material and sections. We follow Dr. John Callomon (pers. comm.) in transferring the entire group from the Virgatosphinctinae to the Perisphinctinae because of the close similarity of some of these forms, for example, Katroliceras and Pachysphinctes, to typical Perisphinctes with the exception of the adult body chamber.

\section{Pachysphinctes beyrichi (Futterer, 1894)}

$$
\text { Pl. 6, figs. 1, 2a,b. Text-fig. } 4
$$

Perisphinctes beyrichi Futterer, 1894:9, pl. 2, figs. 1-3.

Perisphinctes (Virgatosphinctes?) beyrichi-Dacqué, 1910:14, pl. 4, 2a,b.

?Perisphinctes africanus Dacqué, 1910:17, pl. 3, fig. 2.

?Perisphinctes latissimus Zwierzicky, 1914:65, pl. VIII, fig. 4.

?Perisphinctes (Pachysphinctes) africogermanus Dietrich, 1925:12, text-figs. ?1, ?2, and pl. 3, fig. 1 only.

Torquatisphinctes beyrichi-Spath, 1930a:55, pl. 3. fig. 6 [cum synonymy; lectotype des. Futterer, 1894, fig. 2].

?Perisphinctes cf. denseplicatus -Dietrich, 1933:20, pl. 1, fig. 1.

?Torquatisphinctes betsibokensis Collignon, 1959, pl. CIX, fig. 401.

?Subplanites adeloides Spath-Collignon, 1959, pl. 127, fig. 475.

\section{Material}

Four, possibly seven specimens. ROM 34624, damaged, almost complete; from loc. 
8b. KNMI-MA35, small specimen with one-third whorl body chamber well preserved; ?ROM 34620, ?ROM 34746, KNMI-MA36, large specimens with partial body chamber, from loc. 8d. ?ROM 34605, whorl fragment; from loc. 8h. ROM 34733, crushed and incomplete; from loc. $8 \mathrm{j}$.

\section{Description}

The shell is typically planulate with wide and shallow but stepped umbilicus. The whorl section changes from moderately depressed ovate at the nucleus at 20 to $35 \mathrm{~mm}$ diameter $(\mathrm{W} / \mathrm{H} \simeq 0.65)$, to rounded subtrapezoidal or subquadratic in their outer larger whorls.

The ornament consists mostly of moderately dense, high, and sharp biplicate ribbing with a few simple ribs; additional secondaries, however, appear in the adult stage on the outer whorl greater than $100 \mathrm{~mm}$ diameter, beginning low on the flank and producing ataxiocerid ribbing. The primaries are prorsiradiate on the nucleus but rectiradiate on the outer whorls, while the secondaries cross straight over the venter. There are also about three oblique constrictions per whorl.

The septal suture is rather simple, with deep E, slightly shorter L, and several much smaller, oblique, and retracted umbilical elements.

\section{Remarks}

The lectotype of "Perisphinctes" beyrichi Futterer (here refigured, Text-fig. 4) from the ?Kimmeridgian of the Changamwe Shale near Mombasa is a large fragmentary macroconch with an inferred diameter of about $170 \mathrm{~mm}$, while the paralectotype is septate to the end of $71 \mathrm{~mm}$. The intermediate whorls of both specimens (60 to $70 \mathrm{~mm} \mathrm{D}$ ) are rounded, subquadratic, slightly depressed, with steep umbilical wall, and bear 22 to 33 prominent, somewhat prorsiradiate, and partly flexed primaries per half-whorl. While biplication is the rule, rare single ribs and very scarce trifurcation also occur. Trifurcation with irregular fasciculation (ataxiocerid ribbing) is clearly present on the outer whorl of the lectotype, while the secondaries of its penultimate whorl are not visible. The septal suture also agrees with Dietrich's illustration (1925, text-fig. 1) of supposed $P$. africogermanus and our specimens.

Although Dietrich (1925) did not even compare his $P$. africogermanus with $P$. beyrichi, we suggest that the abundant planulate form (not the lectotype) that he placed in his species is probably conspecific with $P$. beyrichi.

Specimens closely resembling the lectotype of $P$. beyrichi occur rarely in the Beckeri Zone, and also in the Hybonotum Zone where they appear to intergrade into more coarsely ribbed forms, that is, 19 to 21 versus 22 to 24 primaries per half-whorl. The coarsely ribbed forms (loc. $8 \mathrm{~d}$ ) with rather short primaries and occasional simple ribs, may perhaps belong to a distinct subspecies. However, no complete specimen has been found and some of the largest specimens may not be fully grown (last septa not approximated).

Collignon (1959) illustrated two similar but poorly preserved "species", respectively from the Hybonotum Zone and Kimmeridgian of Madagascar, under "Subplanites adeloides Spath" and "Torquatisphinctes betsibokensis" Collignon.

\section{Stratigraphic Occurrence}

Locally abundant in the Hybonotum Zone (mainly coarsely ribbed variety; ?subsp.); scarcer in the Beckeri Zone (s. str.), and probably also lower. 


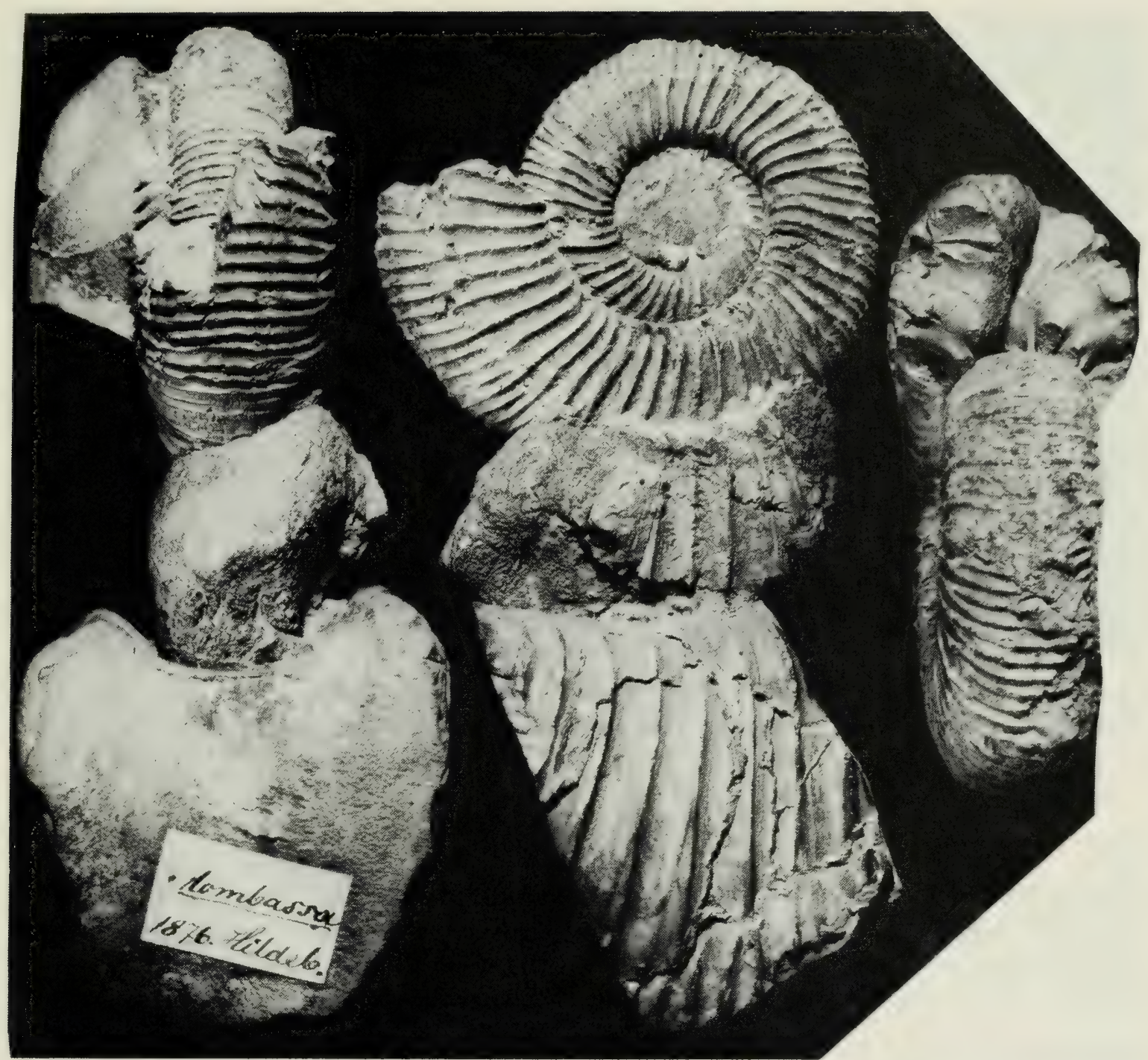

Text-fig. 4 Lectotype of "Perisphinctes" beyrichi Futterer $(\times 0.58)$. Photo courtesy of Drs. H. Jaeger and J. Helms, Museum für Naturkunde der Humboldt-Universität, East Berlin. Note: Zwierzicky's collection was stored outside the museum during the Second World War, and some of the type specimens including the holotype of "Craspedites" africanus Zwierz. were lost. (Dr. J. Helms, pers. comm.).

\section{Measurements}

$\begin{array}{crrrrrr}\begin{array}{l}\text { SPECIMEN NO. } \\ \text { KNMI-MA36 }\end{array} & \mathrm{D} & \mathrm{U} & \mathrm{U} / \mathrm{D} \% & \mathrm{H} & \mathrm{W} & \mathrm{H} / \mathrm{W} \\ \text { body ch. } & \mathrm{c} .122 .0 & 56.0 & \text { c. } 45.0 & - & - & - \\ \text { end phragm. } & 83.0 & 38.5 & 47.0 & 25.5 & \text { c. } 27.0 & \text { c. } 0.95 \\ \text { KNMI-MA35 } & 87.0 & 39.0 & 45.0 & - & - & - \\ \text { body ch. } & 52.0 & 24.0 & 46.0 & \text { c. } 15.0 & \text { c. } 18.5 & \text { c. } 0.8 \\ \text { phragm. } & 46.0 & 20.9 & 45.0 & \text { c. } 14.0 & \text { c. } 17.0 & \text { c. } 0.8 \\ \text { phragm. } & \text { c. } 33.0 & 14.7 & \text { c. } 44.0 & \text { c. } 9.0 & \text { c. } 13.0 & \text { c. } 0.70 \\ \text { phragm. } & 24.6 & 10.3 & 46.0 & \text { c. } 7.1 & 10.8 & \text { c. } 0.65 \\ \text { phragm. } & & & & & & \end{array}$




\title{
Type Species
}

Ammonites pottingeri J. de C. Sowerby, 1840.

\section{Katroliceras pottingeri (Sowerby, 1840)}

\author{
Pl. 4, figs. 1a,b
}

Ammonites pottingeri Sowerby, 1840:719, pl. 61, fig. 10.

(?) Perisphinctes pottingeri-Waagen, 1875:183, pl. LI, figs. 1a,b [= Katroliceras waageni Spath, 1931:508].

Perisphinctes pottingeri-Futterer, 1894:7, pl. 1, figs. 1, 2.

Katroliceras pottingeri-Spath, 1930a:56; Spath, 1931:505, pl. CII, fig. 5 [Futterer, 1894]; pl. LXXXIII, fig. 4; Collignon, 1959, pl. CXXI, figs. 455, 456.

(?)Katroliceras waageni Spath, 1931:508 [for Waagen, 1875].

(?)Katroliceras lerense Spath, 1931:511, pl. LXXXIX, fig. 1.

Katroliceras pottingeri Sowerby var. analavelonensis Collignon, 1959, pl. CXXI, fig. 457.

\section{New Material}

Two or three specimens, more or less strongly crushed and/or distorted. ROM 34749, complete specimen with body chamber; from loc. 8c. KNMI-MA37, phragmocone with body chamber; from loc. $8 \mathrm{~h}$. ?ROM 34748 , fragment of body chamber, from loc. $8 \mathrm{j}$.

\section{Remarks}

The additional number of "species" erected by Spath (1931) on the Kachchh fauna is obviously excessive, and we have here made a tentative attempt at placing some of these into synonymy. For proper taxonomic revision, however, new collections from the exact stratigraphic levels are necessary, as is the examination of all existing material. As a result of Spath's taxonomic splitting, no good specimen of the "true", K. katrolense (sensu Spath) from Kachchh has been figured photographically. The only complete, but exceptionally small specimen figured by Spath (1931, pl. 102) and in the Treatise (Arkell et al., 1957, fig. 425) under that name is Futterer's old specimen from Mombasa.

Futterer (1894) compared his Kenyan "Perisphinctes pottingeri"' with Waagen's specimen from Kachchh which Spath (1931) renamed Katroliceras waageni. Futterer's specimen, however, is a true $K$. pottingeri. Spath (1930a) did not figure his "true" $K$. pottingeri from the Mackinnon Wood collections. Our material has yielded examples which are unquestionably identical to Sowerby's and probably Spath's poorly illustrated Kachchh forms. " $K$. waageni" Spath is said to be distinguished by the depressed subrectangular inner whorls bearing long primaries, but is here tentatively included in $K$. pottingeri, together with several others of Spath's supposed new species.

The holotype of $K$. pottingeri from Kachchh has apparently never been refigured. It is illustrated here (Text-fig. 5), courtesy of Dr. M.K. Howarth, British Museum, Natural History. 


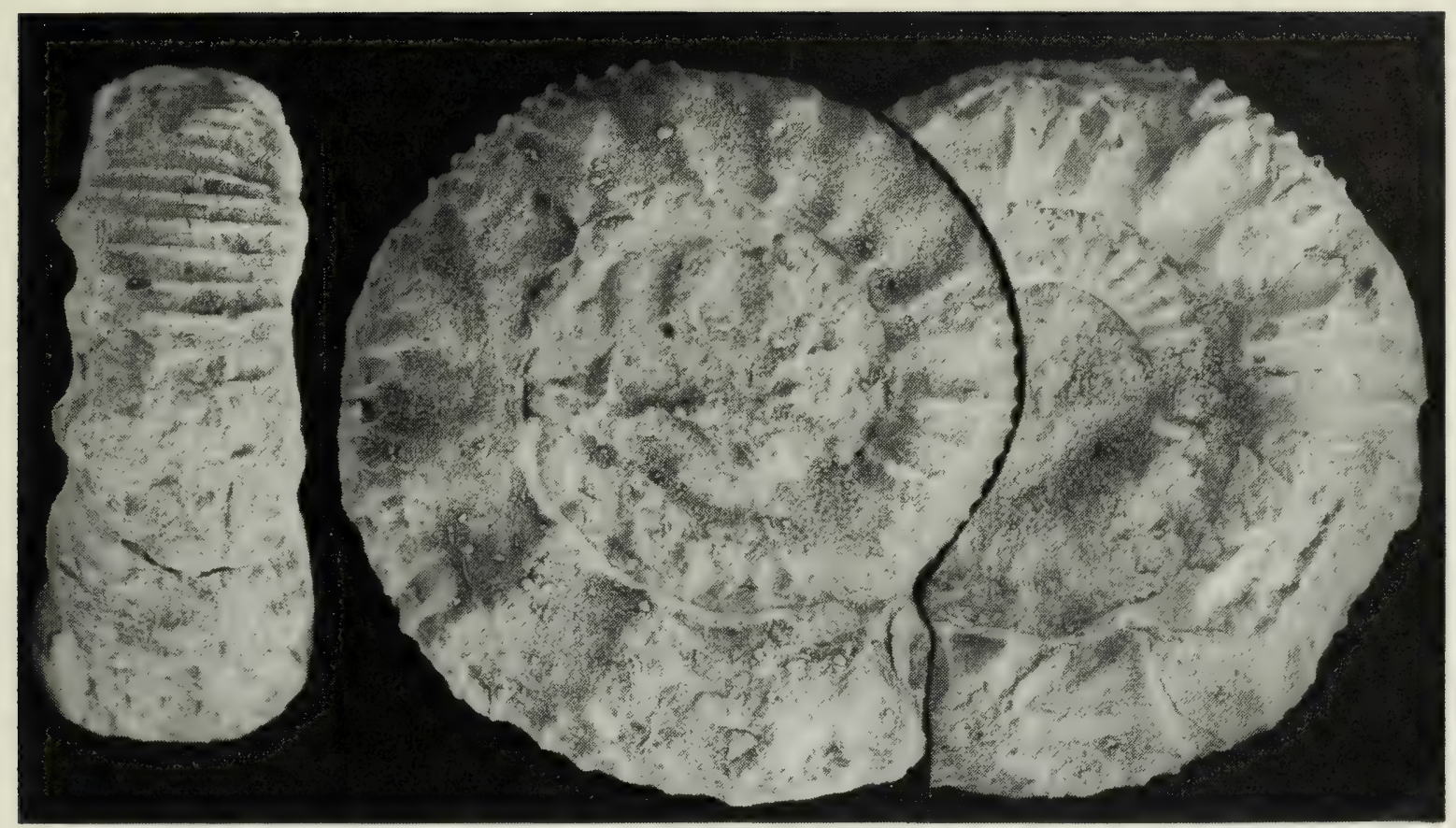

Text-fig. 5 Holotype of Katroliceras pottingeri (J. de C. Sowerby) $(\times 0.58)$. Photograph courtesy of Dr. M. K. Howarth, British Museum, Natural History.

A good series was illustrated by Collignon (1959, figs. 455-57, ?458-61) from the Hybonotum Zone of Madagascar. Collignon, however, appears to have erected an unduly large number of species on his material; many are based only on inner whorls which are similar in many species. The wedge-shaped primaries that usually characterize Katroliceras do not make their appearance until a fairly late stage in growth, so that comparisons between species of this genus should be based upon adult specimens or those in which the characteristic body-chamber ornamentation has started to appear.

\section{Stratigraphic Occurrence}

Rare in Beckeri and Hybonotum Zones.

\section{Measurements}

$\begin{array}{lcccccc}\text { SPECIMEN NO. } & \mathrm{D} & \mathrm{U} & \mathrm{U} / \mathrm{D} \% & \mathrm{H} & \mathrm{W} & \mathrm{H} / \mathrm{W} \\ \text { KNMI-MA37 } & 137.0 & 77.0 & 0.56 & 38.0 & 43.0 & 0.88 \\ \text { ROM } 34748 & 133.0 & 71.0 & 0.53 & 39.0 & 49.0 & 0.79\end{array}$

Katroliceras aff. $K$. pottingeri 우

PI. 4, figs. 2a-c

\section{Material}

One specimen. KNMI-MA38, nearly complete with partial body chamber, from loc. $8 \mathrm{c}$. 


\section{Description}

The shell is large, stoutly planulate, with depressed subrectangular whorl section. The umbilicus is wide and shallow with almost vertical umbilical wall. The coarse primary ribs arise at the umbilical shoulder, are rursiradiate at the umbilical wall, curve forward on the umbilical shoulder, continue prosiradiate over the subparallel flanks, and thicken at the ventro-lateral margin. Up to a diameter of $110 \mathrm{~mm}$ the primaries give rise to convex secondaries traversing the venter. At large diameters, the primaries trifurcate with an occasional intercalatory. Irregularly placed feeble constrictions are present.

\section{Remarks}

This form is characterized by its large size and the broad, stout whorls. The long, coarse primaries probably did not quite reach the wedge-shaped distant stage as in typical $K$. pottingeri, but the body chamber is incomplete. This specimen agrees with Waagen's form, named $K$. waageni by Spath but considered by us to be probably conspecific with $K$. pottingeri. $K$. katrolense (Waagen) has similar ribbing but is much less stout. The Madagascan "Katroliceras pingue Spath" described by Collignon from the Hybonotum Zone (1959, fig. 461) is similar but incomplete.

\section{Stratigraphic Occurrence}

Rare in Hybonotum Zone.

\section{Measurements}

$\begin{array}{lcccccc}\text { SPECIMEN NO. } & \mathrm{D} & \mathrm{U} & \mathrm{U} / \mathrm{D} \% & \mathrm{H} & \mathrm{W} & \mathrm{H} / \mathrm{W} \\ \text { KNMI-MA38 } & 131.0 & 65.0 & 49.6 & 40.0 & 56.0 & 0.71\end{array}$

\section{Katroliceras? cf. K. bathyplocus (Waagen, 1875) ${ }^{\hat{}}$ \\ Pl. 5, figs. 2a,b}

?Perisphinctes bathyplocus Waagen, 1875:192, pl. 50, figs. 1a,b.

?Pachysphinctes bathyplocus -Spath, 1931:493, pl. 77, fig. 1; ?pl.93, figs. 5, 9; pl.

96 , fig. 4.

?Pachysphinctes linguiferus - Spath, 1931:496, pl. 97, fig. 1; pl. 98, fig. 5.

?Pachysphinctes linguiferus - Collignon, 1959, pl. 118, fig. 446.

?Pachysphinctes bathyplocus Waag. var. sparsicostata-Collignon, 1959, pl. 118, fig. 447.

\section{Material}

One, possibly two microconchs, partly with base of lappets, KNMI-MA39, slightly damaged with somewhat crushed body chamber; from loc. 8h. ?ROM 34615, more strongly crushed and inner whorls obliterated; from loc. $8 \mathrm{~b}$.

\section{Remarks}

Our figured specimen closely resembles Waagen's species from the "Middle Katrol Beds" of Kachchh, in particular also the excellent microconchs figured by Spath (1931) under $K$. bathyplocus and $K$. linguiferus. The inner whorls bear rather dense 
but prominent, somewhat prorsiradiate to forward-curved primaries. The outer whorl has biplicate ribs, except for rare simple ribs, and two additional secondaries are present on the body chamber. The aperture has a deep constriction, ventral flare, and the right lateral lappet preserved at $121 \mathrm{~mm}$ diameter.

Our specimen differs from $K$.? bathyplocus in the weak adult modification of the ornament. The primaries continue essentially unmodified but slightly more prominent to the aperture, while only two triple divisions are developed. The figured syntype of Waagen has an incomplete body chamber of at least $130 \mathrm{~mm}$ diameter but already shows strong modification of ornament toward the end with expanded spacing of primaries and several intercalatory and fasciculate secondaries. Therefore, we tentatively transfer this species to Katroliceras. Spath's specimens of " $P$.", bathyplocus and "P." linguiferus also show abundant extra secondaries and expanded spacing of the primaries on the ultimate half-whorl and both appear to be identical with Waagen's species.

Our specimen is therefore somewhat intermediate between Katroliceras, Pachysphinctes, and Subdichotomoceras indicating taxonomic splitting, but we belive it to be a paedomorphic variant or subspecies of $K$.? bathyplocus. A number of similar forms, including this species, also occur in the Hybonotum Zone of Madagascar (Collignon, 1959).

\section{Stratigraphic Occurrence}

\section{Beckeri Zone.}

\section{Measurements}

\begin{tabular}{|c|c|c|c|c|c|c|}
\hline $\begin{array}{l}\text { SPECIMEN NO. } \\
\text { KNMI-MA39 }\end{array}$ & $\mathrm{D}$ & $\mathrm{U}$ & $\mathrm{U} / \mathrm{D} \%$ & $\mathrm{H}$ & W & $\mathrm{H} / \mathrm{W}$ \\
\hline aperture & 121.0 & 57.6 & 47.0 & c. 30.0 & c. 36.0 & c. 0.85 \\
\hline end phragm. & 85.0 & 39.5 & 46.0 & 21.0 & 27.5 & 9.75 \\
\hline
\end{tabular}

Genus Subdichotomoceras Spath, 1925

\section{Type Species}

S. lamplughi Spath, 1925.

\section{Remarks}

The type species is from the Lower Kimmeridgian (s.angl.) of Yorkshire, England, Autissiodorensis Zone (Cope, 1978), correlative with the Beckeri Zone. This is an evolute planulate form with subquadrate whorls, characterized by the very prominent biplicate distant ribbing with rather short primaries, persisting to the adult body chamber and also on the inner whorls.

The genus has usually been considered cosmopolitan in distribution (e.g., Arkell, $1956,1957)$, but doubts have more recently been expressed about the affinity of the Tethyan forms which may be homeomorphs (e.g., Enay, 1973). A brief examination of Uhlig's $(1903,1910)$ work on the Spiti Shales, Himalayas, and of Spath's (1927-33) work on the Katrol Beds of Kachchh, western India, suggests that some 
Katroliceras have septate whorls similar to the more depressed forms of Subdichotomoceras and that some coarsely ribbed Aulacosphinctoides are very close to relatively finely ribbed Subdichotomoceras. Difficulties also arise in the generic separation from Katroliceras of microconchs with persistent biplicate ribbing, with perhaps one or two simple ribs or additional secondaries. Is the absence of the adult modification, so characteristic for Katroliceras (and Pachysphinctes?), simply due to microconchiate, progenetic shortening of the ontogeny, or is the persistent biplication diagnostic for Subdichotomoceras? What taxonomic weight is to be attached to the inner whorls versus the body whorls? Obviously, Spath (1931) had the same difficulties when confronted with the Katrol fauna as is evident from examining his monograph (e.g., pl. 82, figs. 1, 2).

\section{Subdichotomoceras (?) cf. S. sparsiplicatum (Waagen, 1875)}

Pl. 6, fig. 3; Pl. 7, figs. 1a, b; 2

?Perisphinctes sparsiplicatus Waagen, 1875:204, pl. XLIX, figs. 2a,b. Perisphinctes sparsiplicatus-Zwierzicky, 1914:61, pl. VIII, figs. 1,2. ?Subdichotomoceras sparsiplicatum-Spath, 1931:523, pl. 82, fig. 7; pl. 86, fig. 7.

\section{Material}

Three specimens. KNMI-MA7732, entirely septate and partly crushed; KNMI-MA40; from loc. 8d. KNMI-MA7731, septate or with less than one-third whorl body chamber, partly crushed; from loc. $8 \mathrm{c}$.

\section{Description}

The large shell had evolute and probably somewhat depressed (now partially crushed) ovate to subelliptical whorls. The ornament of the phragmocone consists of biplicate, extremely prominent ribs, with 13 to 16 primaries per half-whorl, at least as far back as $20 \mathrm{~mm}$ diameter. The primaries are recti- to somewhat prorsiradiate and divide at or slightly above mid-flank into pairs of radial secondaries. These are only slightly less prominent than the primaries and pass straight over the venter. The phragmocone of two specimens was at least $120 \mathrm{~mm}$ in diameter.

One specimen (Pl. 6, fig. 3) has minute lateral tubercles on the intermediate whorls. The ultimate phragmocone whorl was about as high as broad. The body chamber is unknown except for its beginning which resembles the phragmocone.

One or two deep, oblique, and continuous constrictions per whorl are present on all specimens, usually followed by a simple rib. The septal suture is known only with umbilical elements which are moderately complicated, strongly oblique, and retracted.

\section{Discussion}

According to Spath (1931), S.? sparsiplicatum occurs in the Middle Tithonian uppermost Katrol Beds of Kachchh, not in the basal ones as originally assumed by Waagen (1875:205). The species also occurs in the Lower Tithonian Smeei? and Nerinella beds of the Tendaguru Series in Tanzania, together with Pachysphinctes beyrichi (Futt.) (Zwierzicky, 1914; Dietrich, 1925, 1933; Arkell, 1956). This form resembles Collignon's (1959, pl. 127, fig. 478) "Dorsoplanites? antsalovensis" 
from the Hybonotum Zone of Madagascar, a poorly known form based on a whorl fragment only.

Our specimens (and Zwierzicky's form?) appear to differ from the slightly younger Kachchh species (Spath, 1931) by the more rounded whorl section without a lateral shoulder, although this could be caused by crushing in the other specimens.

\section{Stratigraphic Occurrence}

Hybonotum Zone.

\section{Measurements}

\begin{tabular}{|c|c|c|c|c|c|c|}
\hline SPECIMEN NO. & D & $\mathrm{U}$ & $\mathrm{U} / \mathrm{D} \%$ & $\mathrm{H}$ & W & $\mathrm{H} / \mathrm{W}$ \\
\hline \multicolumn{7}{|l|}{ KNMI-MA7731 } \\
\hline $\begin{array}{l}\text { end phragm./ } \\
\text { beg. body ch. }\end{array}$ & c. 129.0 & 66.0 & c. 51.0 & c. 38.0 & c. 39.0 & c. 0.97 \\
\hline phragm. & c. 84.0 & c. 41.0 & c. 49.0 & c. 26.0 & c. 32.0 & c. 0.81 \\
\hline KNMI-MA7732 & & & & & & \\
\hline phragm. & c. 140.0 & c. 77.0 & c. 55.0 & c. 38.0 & c. 39.0 & \\
\hline
\end{tabular}

Subdichotomoceras? aff. S. sparsiplicatum (Waagen, 1875)

Pl. 5, figs. $1 \mathrm{a}-\mathrm{c}$

\section{Material}

One specimen. KNMI-MA41, almost complete without aperture; from loc. $8 \mathrm{~b}$.

\section{Description}

The shell is planulate, slightly involute with a wide and shallow umbilicus. The umbilical wall is rounded and steep. The whorl section is semicircular with weakly curved flanks and broadly rounded venter. The ornament consists of thin, rather dense primaries which arise at or near the umbilical shoulder. Most of the long primaries bifurcate into very prominent secondaries while a few remain single. Both primaries and secondaries are projected slightly prorsiradiate crossing the venter somewhat convexly. On the body chamber a single trifurcation is also present. Constrictions are present throughout growth but are more distant in the early whorls than in the latter on account of the normally deep intercostal spaces between the primaries.

\section{Remarks}

While the phragmocone resembles that of the relatively compressed Katroliceras ex. gr. katrolense (Waagen) as well as of Pachysphinctes, the body chamber has the biplicate, very broad, and prominent ribbing of Subdichotomoceras. This form, therefore, differs from $P$. sparsiplicatum in the longer primaries and the denser ribbing of the inner whorls.

\section{Stratigraphic Occurrence}

Rare at boundary of the Beckeri and Hybonotum Zones. 
Measurements

$\begin{array}{lcccccc}\text { SPECIMEN NO. } & \mathrm{D} & \mathrm{U} & \mathrm{U} / \mathrm{D} \% & \mathrm{H} & \mathrm{W} & \mathrm{H} / \mathrm{W} \\ \text { KNMI-MA41 } & 114.0 & 63.0 & 55.2 & 32.0 & 36.0 & 0.88\end{array}$

Family Ataxioceratidae Buckman, 1921

Genus Lithacoceras Hyatt, 1900

\section{Type Species}

Ammonites ulmensis Oppel, 1858 (cf. Berckhemer and Hölder, 1959, fig. 50).

\section{Remarks}

The Lithacoceratinae Zeiss, 1968 are included in the Ataxioceratinae. Discosphinctes Dacqué and Subplanites Zeiss respectively were considered to incorporate the Upper Oxfordian and Kimmeridgian-Lower Tithonian microconchs of Lithacoceras by Enay (1966) and Zeiss (1968). The type species of the former, D. arussiorum Dacque from Somalia, is, however, poorly known and its stratigraphic occurrence needs to be reinvestigated. The type species of Subplanites, S. reisi (Schneid), appears to be distinguished from $D$. arussiorum essentially in the ataxiocerid (simple virgatotome) ribbing of the adult body chamber or its terminal portion only. We do not consider the existing evidence strong enough to draw the apparent dimorphs into synonymy, but tentatively include the apparent microconchs in the genus Lithacoceras (s. 1.).

\section{Lithacoceras cf. L. fraasi (Dacqué, 1910) \\ Pl. 8, fig. 2}

?Perisphinctes fraasi Dacqué, 1910:20, pl. 4, fig. 3, text-fig. 10 (lectotype).

?Lithacoceras fraasi-Spath, 1930a:52, pl. 3, fig. 1; pl. 6, fig. 2; pl. 7, fig. 5. ?Lithacoceras fraasi-Collignon, 1959, pl. 103, fig. 386.

\section{Material}

One specimen. KNMI-MA42, partly crushed and incomplete; from loc. 8c.

\section{Remarks}

The species was based only on a small septate specimen (the lectotype) and a fragment. Spath's (1930a) specimens from the Kimmeridgian of Changamwe were also all fragmentary so that the species remains poorly known. Our specimen remains densely ribbed to the preserved end at $114 \mathrm{~mm}$ diameter. Collignon's (1959) specimen from the early Kimmeridgian (pre-Beckeri Zone) of Madagascar is also complete.

This species is characterized by the small umbilicus and the persistence of dense ribbing.

\section{Stratigraphic Occurrence}

The species seems to range through most of the Kimmeridgian into the basal Tithonian. Our specimen is from the Hybonotum Zone. 


\section{Lithacoceras? mombassanum (Dacqué, 1910)}

Pl. 8, figs. 1a,b

Perisphinctes (Virgatosphinctes) mombassanus Dacqué, 1910:15, pl. III, fig. 4; pl. IV, fig. 1.

Lithacoceras mombassanum-Spath, 1930a:48, pl. IV, fig. 1 (lectotype des.: Dacqué, 1910, fig. 1).

Lithacoceras mackinnon-woodi Spath, 1930a:49, text-fig. 2.

Lithacoceras roubyanum - Spath, 1930a:51, text-fig. 3.

?Lithacoceras torquatiforme Spath, 1930a:49, pl. 4, fig. 14.

\section{New Material}

Three to five specimens. KNMI-MA43a, slightly crushed, large and almost complete; from loc. 8k; ?ROM 34734 and ?ROM 34736, incomplete phragmocones; from locs. 8a and 8c; ROM 34737, external mould of partly crushed specimen; from loc. $8 \mathrm{~h}$. KNMI-MA43b, well-preserved juvenile(?); from loc. $8 \mathrm{~d}$.

\section{Remarks}

This species is said to be one of the most common and highly variable forms in the Kimmeridgian of Changamwe (Spath, 1930a). We nevertheless include in this species also L. mackinnon-woodi Spath, his " $L$. roubyanum" (non Fontannes), and perhaps also his L. torquatiforme, since Spath (1930a:48-50) admitted the presence of transitional forms.

\section{Stratigraphic Occurrence}

The species is common in the Kimmeridgian of Mombasa, and may extend into the Hybonotum Zone.

\section{Lithacoceras ef. L. albulum (Quenstedt, 1887)}

$$
\text { Pl. 8, fig. } 3
$$

?Ammonites planulatis albulus Quenstedt, 1887:1076, pl. 125, fig. 8.

?Perisphinctes (Lithacoceras) albulus-Berckhemer and Hölder, 1959:55, pl. 9, fig. 48 ; pl. 10, fig. 51 (holotype refigured); text-fig. 32b.

\section{Material}

One specimen. KNMI-MA44, large phragmocone and half-whor! damaged body chamber without aperture; from loc. $8 \mathrm{~b}$.

\section{Remarks}

According to Berckhemer and Hölder (1959:55) and Zeiss (pers. comm., 1978), $L$. albulum occurs only in the Hybonotum Zone of Swabia and is characterized by the early appearance of virgatotome multiple secondaries and relatively prominent primaries, and by inclined constrictions. Our specimen closely resembles the paratype figured by them as figure 51 , while the holotype has finer secondaries. 


\section{Stratigraphic Occurrence}

Rare at boundary of the Beckeri and Hybonotum Zones.

\section{Genus Phanerostephanus Spath, 1950}

\section{Type Species}

P. subsenex Spath, 1950.

\section{Discussion}

Spath (1950) created the genera Phanerostephanus and Nothostephanus on the basis of Upper Jurassic material from Jebel Gara near Amadia in Kurdistan, northern Iraq. He placed Phanerostephanus in the subfamily Virgatosphinctinae and Nothostephanus tentatively in the Virgatitinae, but Arkell et al. (1957:L330) considered both "genera" as Virgatosphinctinae. Phanerostephanus included $P$. subsenex (type species), $P$. hudsoni, $P$. intermedius, and $P$. dalmasiformis, all described by Spath. Nothostephanus, however, was based on the single, and so far only known, species $N$. kurdistanensis Spath, with unknown body chamber. The closer examination of the "genera" reveals several similarities. Both are compressed platycones with depressed circular whorl sections in the early whorls, giving rise to high whorl sections with arched venters in the later whorls. Virgatotome to fasciculate ribbing characterizes the early whorls including the main portion of the phragmocone, giving rise to broad umbilical tubercles and smooth flanks in later whorls including the body chamber. Both have irregularly spaced, shallow constrictions. The septal suture is nearly identical, the adult suture consisting of a broad external saddle, a trifid lateral lobe, which is almost as deep as the external lobe or deeper, and two more saddles on the whorl side (Spath, 1950:104, 115). The only marked differences between the two "genera" are the degree of involution and the growth stage at which the ornament transition occurs. Both features, however, vary intraspecifically.

By and large, the adult shell of Nothostephanus kurdistanensis is involute; the umbilical width of the holotype and of other specimens figured by Spath (1950, pl. 7, figs. $1-4,8)$ ranges from 20 to 25 per cent of the diameter. The umbilical widths of Phanerostephanus subsenex, $P$. hudsoni, and $P$. intermedius range from 35 to 47 per cent (Text-fig. 6). Measurements of the better-preserved specimens of $P$. (N.) digoi sp. nov. indicate that it has an enlarged umbilicus in the outer whorls even after the uncoiling normally observed in the last whorl of adult ammonites is taken into consideration. The umbilical width of the inner phragmocone whorls ranges from 19 to 26 per cent. In adult specimens, however, uncoiling proceeds ( 29 to $41 \%$; Text-figs. 6, 7). This appears to indicate that the new form described here includes the range covered by both Nothostephanus and Phanerostephanus.

With regard to the ornamentation, it should be pointed out that Nothostephanus is known mainly from the phragmocone. The holotype has only a very small portion of the body chamber which is crushed (Spath, 1950, pl. 7, fig. 1a). Presumably on the basis of the other material in his collection of about 30 fragmentary and crushed specimens, Spath (1950:115) stated that "the secondary ribs seem to disappear on the body chamber and probably only the blunt and rounded umbilical tubercles remain.", 


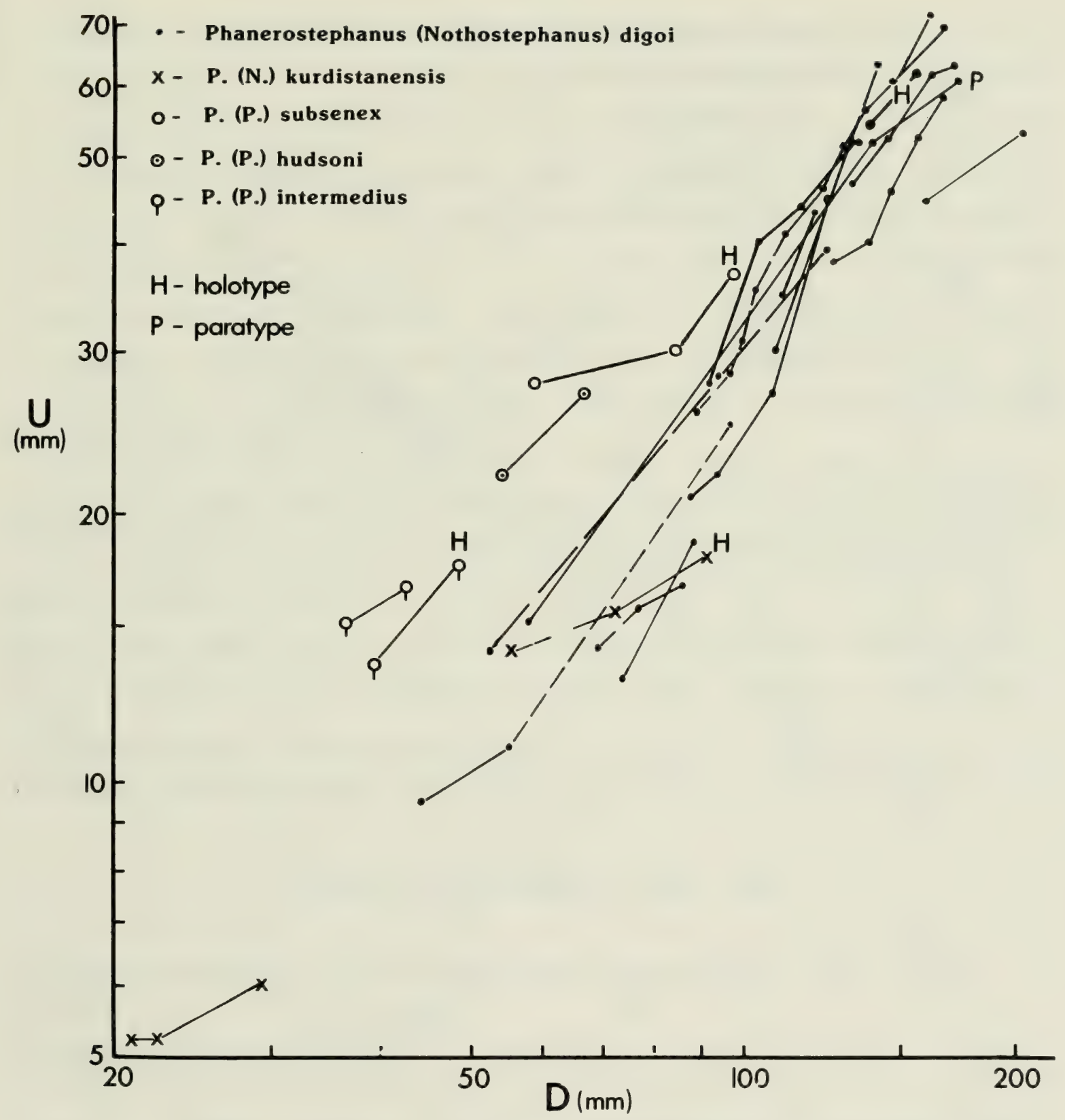

Text-fig. 6 Umbilical width (U) versus the diameter (D) of Phanerostephanus (Nothostephanus) digoi sp. nov. as compared with Spath's species of $P$. (P.) subsenex, $P$. (P.) hudsoni, P. (P.) intermedius, and $P$. (N.) kurdistanensis.

On the other hand, the incomplete holotype of Phanerostephanus subsenex is an adult specimen of about the same size as the phragmocone of Nothostephanus kurdistanensis, and has a ribbed phragmocone and a smooth body chamber with blunt and rounded tubercles.

The principal difference in the ribbing habit between the two "genera", here considered subgenera, thus appears to be the growth stage at which the ribs at the umbilical margin are transformed into swollen tubercles and the ribs on the whorl flanks and venter become obsolete. The adult specimens of $P$. (N.) digoi sp. nov. superficially resemble $P$. (N.) kurdistanensis in the smooth outermost whorl and the wavy umbilical margin. The inner whorls (Pls. 9, 10) display the tight coiling and virgatotome ribbing characteristic of the juvenile $P$. (Nothostephanus).

Another genus closely related to both subgenera Nothostephanus and Phanerostephanus and also occurring in the Lower Tithonian of the Ethiopian Province 


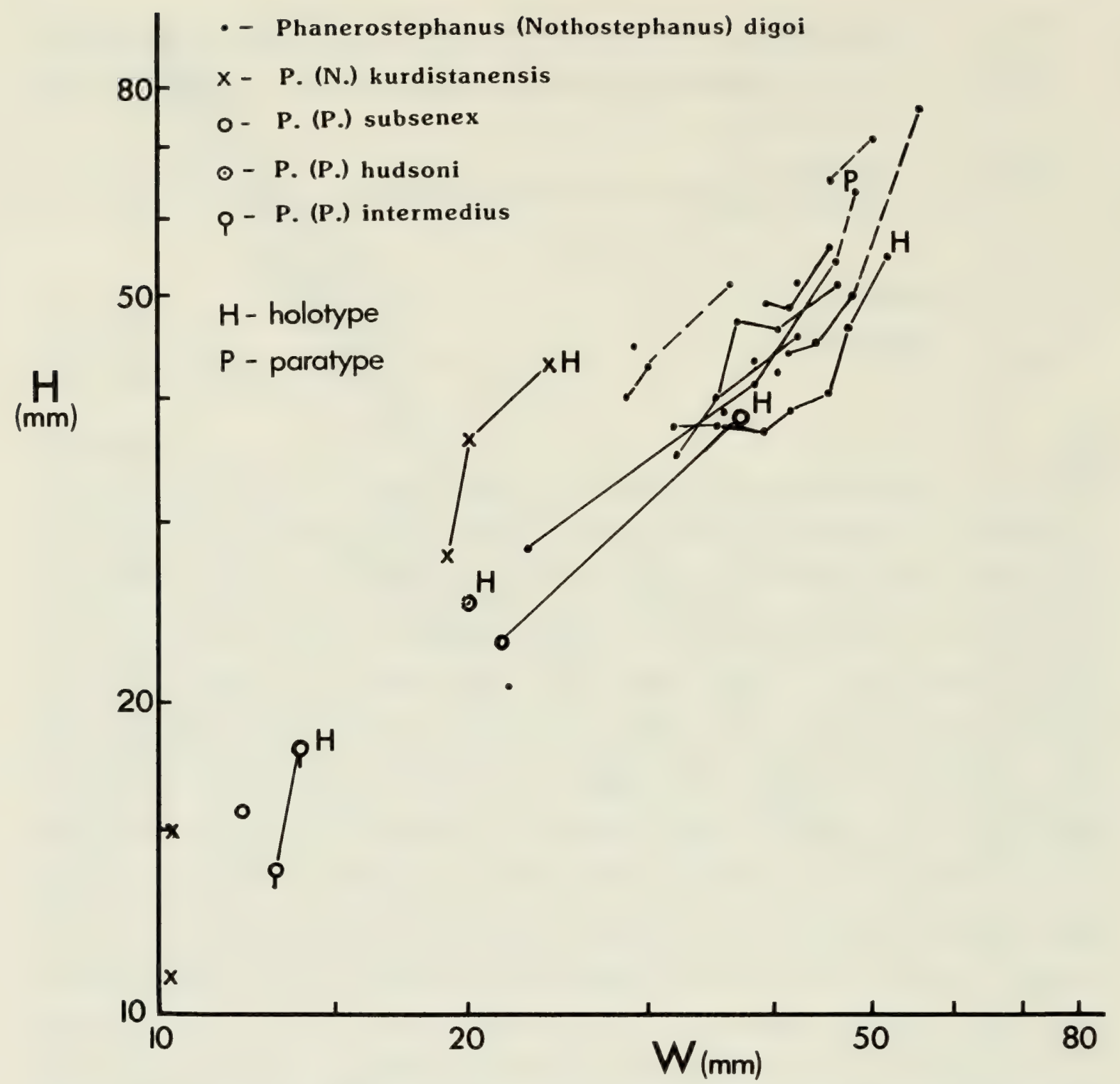

Text-fig. 7 Whorl heigth $(\mathrm{H})$ versus whorl width (W) of Phanerostephanus (Nothostephanus) digoi sp. nov. as compared with Spath's species of $P$. $(P$.) subsenex, $P$. ( $P$. $)$ hudsoni, $P$. $(P$.) intermedius, and $P$. (N.) kurdistanensis.

(Somalia) and in Argentina?, is Pseudoinvoluticeras Spath (type species $P$. somalicum Spath). According to Spath (1950:115) Phanerostephanus (Nothostephanus) displays the greatest affinity to that genus which is also very tightly coiled and finely ribbed followed by a smooth stage.

Pseudoinvoluticeras, Phanerostephanus (s. str.), and P. (Nothostephanus) appear to form a group of highly specialized Ataxioceratinae which, probably on account of their common perisphinctid root, share the involute to moderately evolute coiling, the simple virgatotome (ataxiocerid) to fasciculate ribbing in the early whorls, the common presence of umbilical tubercles, and the obsolescence of ribbing on the flanks. They range from highly involute forms (Pseudoinvoluticeras, Nothostephanus) to moderately evolute (Phanerostephanus). The Mombasa species described below is morphologically intermediate between Phanerostephanus (Nothostephanus) kurdistanensis Spath and P. (Phanerostephanus) subsenex Spath. 
Additional support for the close affinities between $P$. (Nothostephanus) and Phanerostephanus (s. str.) comes from Spath (1950:114) who admitted the existence of transitional forms. After sending his 1950 paper to the press, he found a form "'almost exactly halfway between his Phanerostephanus subsenex and $P$. hudsoni, also distinctly transitional to the more involute Nothostephanus" (Spath, 1950:1067). Zeiss (pers. comm.) is of the opinion that our Mombasa form somewhat resembles both of what he considers the genera Nothostephanus and Phanerostephanus and that it should therefore be assigned to a new genus. We believe that the literature of Mesozoic ammonites, particularly of the Middle and Upper Jurassic, is already overburdened with generic names, many of which are of dubious value (cf. also Arkell et al., 1957:L328). An additional generic name would only increase the existing confusion rather than resolve it.

Enay et al. (1971) have described a fauna including Phanerostephanus, Hybonoticeras, and Pseudoinvoluticeras from the Lower Tithonian Degirmenlik beds of the Anatolian region (Taurus, south of Beysehir) in southern Turkey. This fauna shows remarkable similarities to the Kurdistan fauna of Spath with identical species: Phanerostephanus subsenex, $P$. hudsoni, and $P$. intermedius. In Enay's opinion (pers. comm.) some of our specimens could perhaps be placed in Phanerostephanus (s. str.), but they would be transitional between Spath's Iraq fauna and the Turkish fauna.

We consequently include Nothostephanus as a subgenus in Phanerostephanus, and consider Pseudoinvoluticeras to be its closest ally.

Subgenus Nothostephanus Spath, 1950

\section{Type Species}

N. kurdistanensis Spath, 1950.

Phanerostephanus (Nothostephanus) digoi sp. nov. 우

Pl. 9, fig. 1a; Pl. 10, figs. 1-3. Text-figs. 6-9

\section{Holotype}

Specimen KNMI-MA21a, a well-preserved undistorted internal mould of an adult specimen with some test preserved; both sides and venter exposed.

\section{Type Locality and Horizon}

Loc. 8e, $0.5 \mathrm{~km}$ south the New Mto Panga Quarry, $3 \mathrm{~km}$ north of Freretown, about $8 \mathrm{~km}$ northeast of Mombasa $\left(4^{\circ} 00^{\prime} \mathrm{S} ; 39^{\circ} 42^{\prime} \mathrm{E}\right)$. Upper Changamwe Shales, bed $e$ at 50 to $100 \mathrm{~m}$ below top of section,

\section{Paratypes}

Specimen KNMI-MA21b, adult shell with one-quarter whorl incomplete body chamber, part of outer whorls removed to show ribbed venter and sides of adolescent stage; KNMI-MA45, undistorted phragmocone with inner whorls isolated to expose 
whorl sides and venter; KNMI-MA46, phragmocone with part of body chamber, inner whorls isolated; all from loc. $8 \mathrm{e}$.

\section{Etymology}

After the Wa Digo tribe, native to coastal parts of the Mombasa area.

\section{Stratigraphic Occurrence}

Lower Tithonian, Hybonotum Zone.

\section{Diagnosis}

A large species of $P$. (Nothostephanus) with tight inner coiling and rather evolute outer whorls; primary ribs on the umbilical margin thickening to nodes on the middle whorls and finally becoming sparse undulations on the body chamber; virgatotome to fasciculate secondaries on the early whorls, becoming obsolescent; body chamber smooth except for large umbilical undulations.

\section{Additional Non-type Material}

Eleven specimens in addition to the holotype and the paratypes, all from loc. 8e. ROM 34527 , adult specimen with crushed body chamber except in the apertural region; ROM 34528, adult specimen with about one-third of the outer whorl crushed; ROM 34530 , incomplete phragmocone with well-preserved inner whorls; ROM 34531, adult specimen with body chamber crushed in the apertural region; ROM 34532, crushed phragmocone; ROM 34533, adult shell with laterally crushed body chamber, the largest specimen in the collection; ROM 34534, adult shell with body chamber broken off; ROM 34535, undistorted adult shell with earlier part of the body chamber missing; ROM 34536, adult specimen with part of body chamber missing; ROM 34537 , fragmentary specimen showing section of inner whorls; ROM 34788, adult shell with exposed suture line, slightly distorted in the apertural region.

\section{Description}

The shell is planulate and large (150 to $220 \mathrm{~mm})$, tightly coiled, with subcircular section in the early whorls changing via trapezoidal to compressed subrectangular in the later whorls (Text-fig. 8). The whorl overlap is 70 to 85 per cent in the early whorls, reducing to about 40 per cent in the later whorls. In the outermost whorls the flanks are almost flat, moderately converging, and the venter is semicircular. The whorl overlap has often broken away, giving a false impression of open coiling. The test is rather thick, reaching $3 \mathrm{~mm}$ in KNMI-MA21b. The umbilicus is small and deep in the inner whorls, enlarging towards the outer whorls; with the almost vertical slope the innermost whorls become gradually more shallow.

The inner whorls have coarse single ribs which arise from the umbilical margin and traverse the flanks and venter rectiradiate. Beyond this stage the ribs abruptly thicken to umbilical nodes from which several ribs radiate out to the ventro-lateral shoulder and traverse the venter regularly. The nodes gradually become sparse and blunt so that at about $90 \mathrm{~mm}$ diameter only faint undulations remain on the umbilical margin. The lower half of the ribs arise at about the middle of the flanks and cross the venter. In the succeeding growth stage, the ribs gradually also begin to fade on the venter so that from about $110 \mathrm{~mm}$ diameter the venter is entirely smooth. The umbilical 

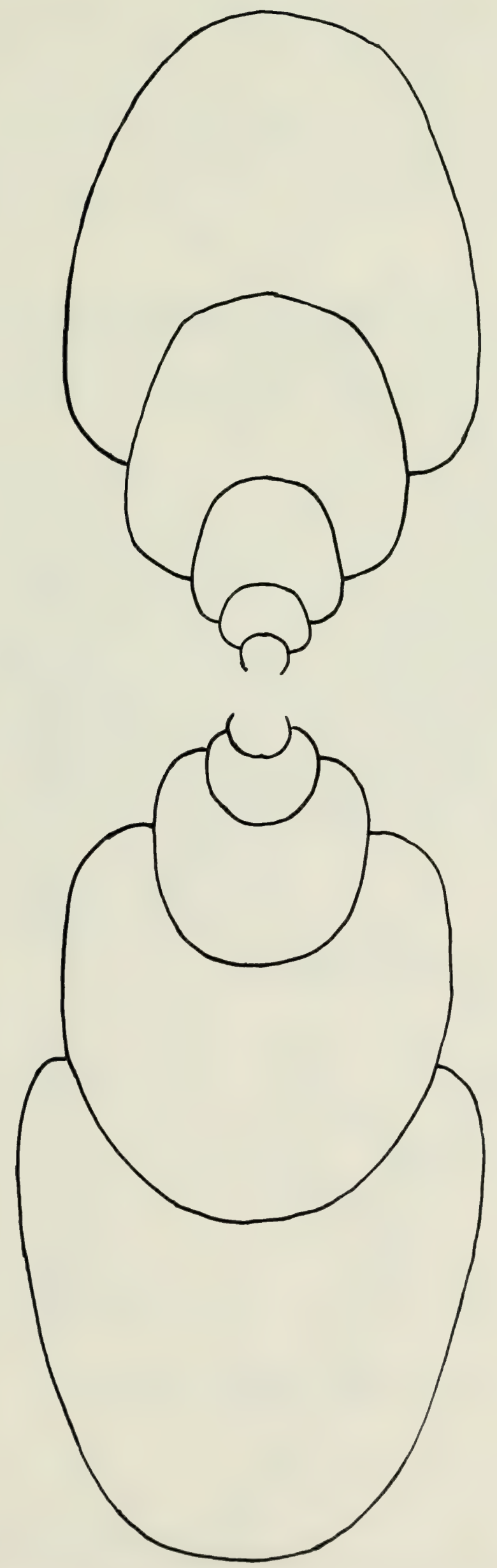

Text-fig. 8 Whorl section of Phanerostephanus (Nothostephanus) digoi sp. nov. $(\times 1)$. 


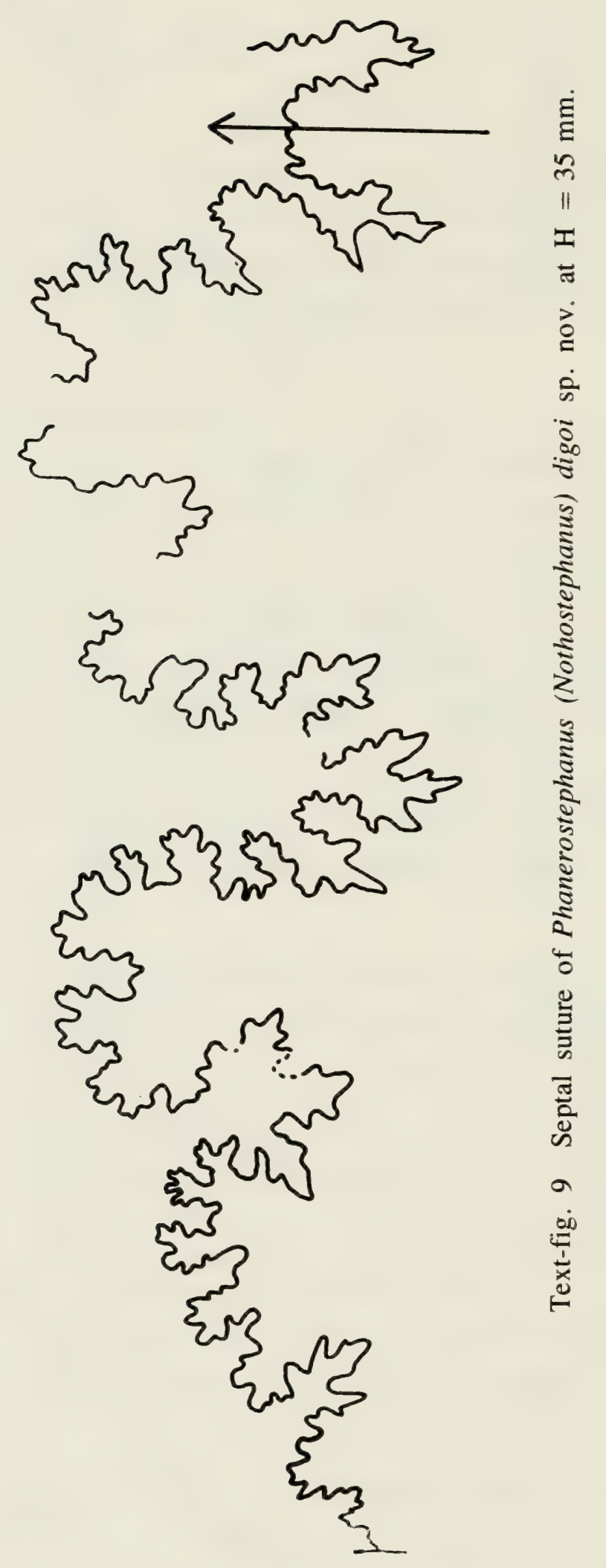


undulations, however, persist, becoming much thicker and more widely spaced, and giving a wavy appearance to the umbilical margin. Consequently the fully grown specimen is smooth except for the umbilicus, and the ribbing of the specimens can be observed only by isolating the inner whorls ( $\mathrm{Pl}$. 10, figs. 1a-c). The adult septal suture (Text-fig. 9) consists of a broad external lobe with a broad median saddle, a very broad external saddle, a moderately deep lateral lobe, a lateral (" 2 nd lateral' ") lobe about half as deep as the lateral lobe, and four to five further umbilical lobes.

\section{Discussion}

At the specific level $N$. digoi differs from $N$. kurdistanensis (Spath) in the much larger size, the more rounded venter, and the coarser ribs at similar diameters. Spath (1950:116) also mentioned the superficial resemblance between the outer whorls of N. kurdistanensis and Proniceras jimulcense Imlay (1939:55, pl. XVII, figs. 1-3) from Mexico.

Our species is closely similar to Pseudoinvoluticeras limitis (Burckhardt, 1906) ["Perisphinctes aff. erinus d'Orb." in Burkhardt, 1906] from Mexico in the umbilical undulations of the outer whorls; but $P$. limitis is smaller, thicker at similar size, and retains the ribbing on the venter throughout growth; most importantly, the lateral lobe is much thinner and deeper. $P$. limitis differs from "Ammonites" erinus d'Orbigny in the larger size, the persistence of ventral ribbing, and the much thinner and deeper lateral lobe. Procraspedites mazapilensis (Burckhardt, 1906), also from Mexico, resembles our species only in the loss of ribbing in the outer whorls; the whorl section is higher, almost fastigate, and umbilical tubercles are absent in the Mexican species. "Perisphinctes" erinoides Burckhardt is probably synonymous with Pseudoinvoluticeras limitis; suture line, whorl shape, and ornament are nearly identical.

\section{Measurements of Type Specimens}

$\begin{array}{lrrrrrr}\begin{array}{l}\text { SPECIMEN NO. } \\ \text { KNMI-MA21a }\end{array} & \mathrm{D} & \mathrm{U} & \mathrm{U} / \mathrm{D} \% & \mathrm{H} & \mathrm{W} & \mathrm{H} / \mathrm{W} \\ \begin{array}{l}\text { (Holotype) } \\ \end{array} & 153.0 & 63.0 & 41.0 & 55.0 & 51.0 & 1.07 \\ & 135.0 & 56.0 & 41.0 & 42.0 & 45.0 & 0.93 \\ & 121.0 & 46.0 & 38.0 & 38.0 & 39.0 & 0.97 \\ \begin{array}{l}\text { KNMI-MA21b } \\ \text { (Paratype) }\end{array} & 171.0 & \text { c. } 61.0 & 35.0 & \text { c. } 64.0 & \text { c. } 48.0 & \text { c. } 1.33 \\ & 139.2 & 52.5 & 39.0 & \text { c. } 41.0 & 38.5 & 1.06 \\ & 58.0 & 15.0 & 25.0 & 28.5 & 23.5 & 1.21\end{array}$

Family Aulacostephanidae Spath, 1924

Genus Procraspedites Spath, 1930

\section{Type Species}

Craspedites praecursor Burckhardt, 1906. 


\section{Procraspedites cf. P. africanus (Zwierzicky, 1914) 우 \\ Pl. 11, figs. 1a,b; 2}

?Craspedites africanus Zwierzicky, 1914:59, fig. 24; pl. 7, fig. 9.

Groebericeras sp.-Arkell, in Eames and Clarke, 1964; Walters and Linton, 1973: 140 .

\section{Material}

Two specimens. ROM 34604, phragmocone with partially preserved body chamber; from a locality about $600 \mathrm{~m}$ southwest of the New Mto Panga Shale Quarry (above bed 8e). KNMI-MA47, incomplete specimen; from loc. $8 \mathrm{f}$.

\section{Description}

The shell is large, discoidal, involute, and elliptical in whorl section. The flanks are weakly convex and the venter narrowly rounded in the inner whorls, broadly rounded in the inflated body whorl which egresses markedly. The umbilicus of the phragmocone is narrow ( $\mathrm{U} \simeq 20 \%$ of $\mathrm{D}$ ), with steep umbilical wall and rounded shoulder. Umbilical width increases to 30 to 35 per cent with the body chamber. The flanks of the outer phragmocone whorl are mostly smooth. Densely spaced, rather blunt secondaries arise only at two-thirds to three-quarters whorl height, about 23 to 25 per quarter-whorl. They project slightly and traverse the venter in a straight line. These ribs become obsolete on the body chamber. The larger of our two specimens shows one well-marked constriction at a diameter of about $110 \mathrm{~mm}$. The spetal suture is simple, with a broad (first) lateral saddle $\mathrm{L} / \mathrm{U}$, a thinner and deeper (first) lateral lobe $\mathrm{L}$, and three to four umbilical lobes of gradually diminishing strength (Pl. 11, fig. 1a).

\section{Remarks}

This form is intermediate in the density of secondary ribbing (23 to 25 per quarter-whorl) between the Mexican $P$. mazapilensis (Burckhardt) (c. 35) and the Tanzanian $P$. africanus (c. 18), but slightly closer to the latter which it also resembles in the somewhat stronger inflation of the whorls. Zwierzicky correctly compared his poorly preserved specimen from the ?Trigonia smeei Bed of Tendagaru with the Mexican "Craspedites" mazapilensis Burckhardt (1912:100, pl. 17, figs. 1-4) which is now placed in Procraspedites. Zwierzicky's strongly corroded specimen, however, was found by natives in a riverbed and originally referred to "mainly Smeei-bed?" [from German] (Janensch and Hennig, 1914:5). The only specimen, that is, the holotype, was lost during the Second World War, according to Dr. H. Jaeger of the Museum für Naturkunde der Humboldt-Universität, East Berlin (pers. comm.).

The identification of specimen ROM 34604 as "Groebericeras sp." by such an authority as the late W.J. Arkell (in Eames and Clarke, 1964) led Haw (1964) and Walters and Linton (1973) to believe that the uppermost part of the "Upper Jurassic Shales" (Changamwe Shales) exposed in the vicinity of the New Mto Panga Quarry is Neocomian in age. The specimens before us are distinctly more involute and have a 
septal suture markedly different from the type species of Groebericeras: $G$. planifrons Leanza (1945:82, pl. XVII, figs. 2, 5; pl. XVIII, fig. 1; pl. XIX, figs. 1, 2, 7; text-fig. 11) from the basal Cretaceous of Argentina. Although superficially strongly reminiscent of Groebericeras, whorl section, coiling, and septal suture are similar to that of Procraspedites mazapilensis Burckhardt, a species from the "Haploceras [Glochiceras] fialar beds" [ $=$ Kimmeridgian] of Mexico. In the absence of any other unequivocal evidence we do not see any justification for the presence of basal Cretaceous (and Upper Tithonian) in the Freretown area. The Mexican Procraspedites praecursor (Burckhardt, 1906:98, pl. XVIII, figs. 1-3), type species, has a coiling similar to $P$. mazapilensis but the lower three-quarters of the flank in the early whorls is covered by broad undulations.

\section{Stratigraphic Occurrence}

Upper Hybonotum Zone.

\section{Measurements}

$\begin{array}{lcccccc}\text { SPECIMEN NO. } & \mathrm{D} & \mathrm{U} & \mathrm{U} / \mathrm{D} \% & \mathrm{H} & \mathrm{W} & \mathrm{H} / \mathrm{W} \\ \text { ROM } 34604 & \text { c. } 169.0 & \text { c. } 55.0 & 32.5 & 69.0 & 51.0 & 1.35 \\ \text { KNMI-MA47 } & 148.0 & \text { c. } 35.0 & 23.6 & \text { c. } 58.0 & \text { c. } 34.0 & 1.70\end{array}$

\section{Genus Gravesia Salfeld, 1913}

\section{Type Species}

Ammonites gravesianus d'Orbigny, 1850; by subsequent designation of Roman, 1938.

Gravesia loupekinei sp. nov. 우

Pl. 11, figs. 3a,b; Pl. 12, figs. 1a-c, 2a-c, 3. Text-fig. 10

\section{Holotype}

Specimen KNMI-MA22, a complete, slightly distorted internal mould, penultimate whorl damaged and mostly removed to expose inner whorls.

\section{Type Locality and Horizon}

Locality $8 \mathrm{e}, 0.5 \mathrm{~km}$ south of the New Mto Panga Quarry, $3 \mathrm{~km}$ north of Freretown, about $8 \mathrm{~km}$ northeast of Mombasa $\left(4^{\circ} 00^{\prime} \mathrm{S}, 39^{\circ} 42^{\prime} \mathrm{E}\right)$. Upper Changamwe Shales, bed $e$ at 50 to $100 \mathrm{~m}$ below top of section.

\section{Paratypes}

Three internal moulds. KNMI-MA48, slightly distorted phragmocone with outer whorl removed to expose the penultimate whorl; KNMI-MA49, weathered phragmocone with body chamber; from loc. 8d. ROM 34819 (RGM 1890), incomplete phragmocone; from " "just under 2 miles north-north-west of junction of track to Nguu Tatu and main coast road and about 350 yards west of track." 


\section{Etymology}

In honour of Professor I.S. Loupekine, head of the Department of Geology, University of Nairobi, Kenya.

\section{Stratigraphic Occurrence}

Lower Tithonian, Hybonotum (or "Gravesia") Zone.

\section{Diagnosis}

An involute, weakly inflated species of Gravesia with intermediate whorls bearing distant large umbolateral nodes or bullae (c. 5 per half-whorl) and blunt secondaries, and usually smooth outer one to two whorls.

\section{Description}

The complete shell is moderately large (c. $150 \mathrm{~mm}$ ) and almost planulate, owing to the moderate inflation of the inner whorls and the egression and rounding of the outer one to two whorls. The inner whorls are relatively involute for Gravesia (U/D $=30$ to $36 \%)$ and moderately depressed $(\mathrm{H} / \mathrm{W}=0.65$ to 0.8$)$, with steep, almost vertical umbilical wall rounding via a narrow flank into the evenly curved venter. Up to about 40 to $45 \mathrm{~mm}$ diameter, they bear moderately spaced primary costae (c. eight to 10 per half-whorl) which divide at about the middle of the whorl height into two to three somewhat convex, continuous secondaries. Subsequently, the primaries become more widely spaced, developing rapidly into prominent bullae and, finally, into large rounded, bullate nodes, only about five per half-whorl. The secondaries retain their original modest spacing and convexity, so that there are now three to five blunt secondaries (including intercalatories) per node. On the last phragmocone whorl, both the distant nodes and the secondaries become blunt to varying degrees, and, finally, obsolete. The outer whorl of the shell, including the body chamber, is therefore smooth except for incipient distant lateral swellings or, exceptional, very blunt lateral nodes (five to six per half-whorl; Pl. 12, fig. 1a).

The adult body chamber is three-fifths to three-quarters of a whorl in length and marked by gradual but appreciable egression and rounding with negative allometry particularly of width growth. The internal mould is smooth except for the incipient lateral swellings. These are faintly present on the holotype and more prominent on KNMI-MA49 (PI. 11, figs. 3a,b).

The septal suture (Text-fig. 10) is very simple with radial saddle envelope, broad and deep external lobe, slightly less deep lateral lobe, and two to three umbilical lobes of diminishing size.

\section{Remarks}

The species resembles $G$. gigas (Zieten) in coiling and whorl section, but differs in the ornament and the smaller size; the nodose growth stage is restricted to the intermediate instead of the outer whorls as in G. gigas. Thus, at a diameter of 50 to $100 \mathrm{~mm}$, there are only four to six bullae per half-whorl in $G$. loupekinei compared to eight to 10 in $G$. gigas. The reduction of ornament occurs earlier than in previously known species of Gravesia (for review see Hahn, 1963), with the exception of $G$. irius (d'Orbigny) (holotype refigured in Hahn, 1963, pl. 12, fig. 2). This rare western European species has similar ornamentation, but much more depressed, broader, and 


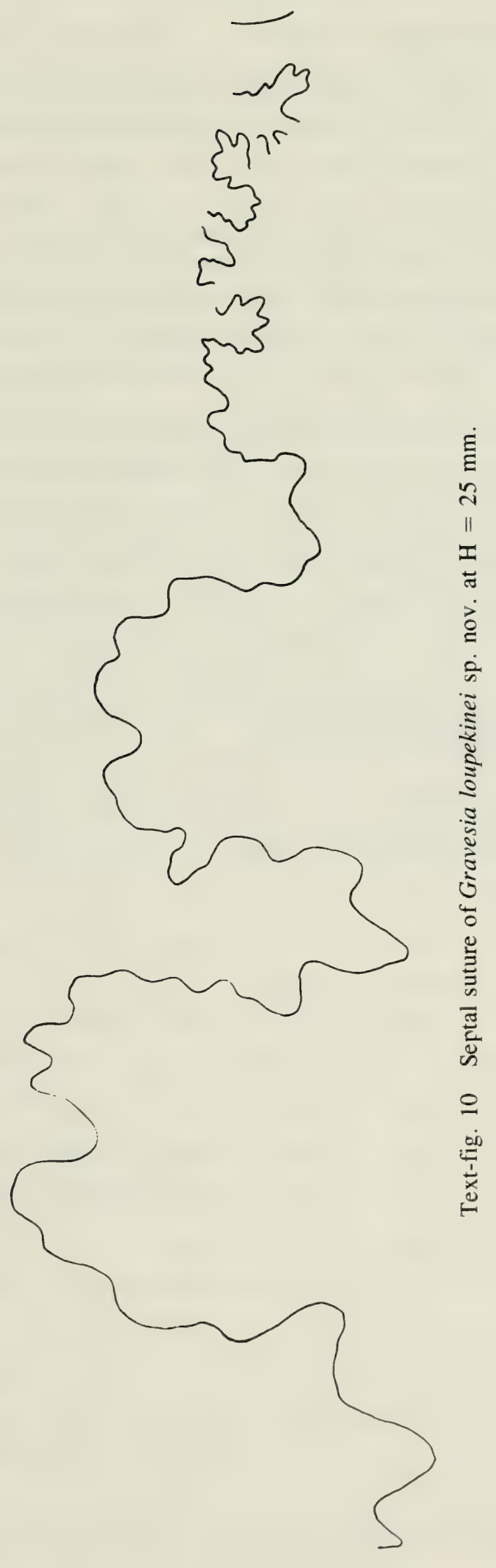


more involute whorls. Our new species thus combines the whorl shape of G. gigas with the ornament of $G$. irius.

The European stratigraphic distribution of Gravesia is restricted to the Lower Tithonian Hybonotum Zone in which, in contrast to earlier opinions, the five recognized species appear to occur either in association or in time-equivalent beds (Barthel, 1959; Hahn, 1963; Cope and Zeiss, 1964; Enay, 1966, 1973; Zeiss, 1968). The occurrence of Gravesia also in East Africa (and ?Madagascar) is remarkable because the other occurrences are restricted to western Europe, that is, to France, Germany, and southern England (op. cit.), and perhaps also to the Russian platform and western Siberia (Zeiss, pers. comm.). Perhaps the disjunct geographic distribution is due to the unusually strong ecological restriction of Gravesia which Zeiss (1968:152) considers to be the inner sublittoral (c. 10 to $40 \mathrm{~m}$ depth); the genus occurs in Europe in similar association with perisphinctids, aspidoceratids, and Hybonoticeras.

The credit for the significant discovery of Gravesia in East Africa should go to Arkell who identified specimen RGM 1891 (British Petroleum-Shell Development Company's collections) with Gravesia cf. G. portlandica (de Loriol). That species is now regarded as a junior synonym of $G$. gigas (Hahn, 1963:98; neotype pl. 9, fig. 1). Arkell's identification in Linton and Maclean's report (1955), however, remained unpublished. To our knowledge the only previous record of Gravesia outside Europe and western Siberia is that of Collignon who figured a minute specimen $(D=21 \mathrm{~mm})$ from Madagascar as Gravesia? sp. indet. (1960, fig. 647). Because of its doubtful identity, Hahn (1963) and Enay (1966) correctly regarded this occurrence as poor evidence for the distribution of Gravesia.

\section{Stratigraphic Occurrence}

Rather common in the Hybonotum Zone.

\section{Measurements}

\begin{tabular}{|c|c|c|c|c|c|c|}
\hline SPECIMEN NO. & $\mathrm{D}$ & U & $\mathrm{U} / \mathrm{D} \%$ & $\mathrm{H}$ & W & $\mathrm{H} / \mathrm{W}$ \\
\hline \multirow[t]{2}{*}{ KNMI-MA48 } & c. 80.0 & c. 19.0 & - & 一 & - & 一 \\
\hline & 51.0 & 17.0 & 33.0 & c. 18.5 & $\begin{array}{c}\text { c. } 27.0 \\
(30.0)\end{array}$ & c. 0.70 \\
\hline \multicolumn{7}{|l|}{ Holotype } \\
\hline end body ch. & 153.0 & 64.0 & 41.0 & 48.0 & c. 52.0 & c. 0.90 \\
\hline end phragm. & 116.0 & 46.0 & 40.0 & 48.5 & c. 48.0 & c. 1.00 \\
\hline KNMI-MA49 & c. 61.0 & 22.2 & 36.0 & 23.0 & $\begin{array}{c}35.0 \\
(38.5)\end{array}$ & c. 0.66 \\
\hline apert. & 142.0 & 65.0 & 45.7 & 43.0 & $\begin{array}{c}49.0 \\
(51.0)\end{array}$ & 0.87 \\
\hline \multirow[t]{2}{*}{ end phragm. } & 96.0 & 32.0 & 33.0 & 36.5 & - & - \\
\hline & 90.0 & 26.8 & 30.0 & 36.0 & $\begin{array}{c}43.0 \\
(45.0)\end{array}$ & 0.82 \\
\hline ROM 34819 & 67.0 & c. 22.0 & c. 33.0 & 29.0 & $\begin{array}{c}40.0 \\
(44.0)\end{array}$ & 0.60 \\
\hline
\end{tabular}


Gravesia aff. G. loupekinei sp. nov. 우

PI. 13, figs. 1a-d

\section{Material}

One specimen. KNMI-MA50, well-preserved phragmocone, slightly damaged internal mould with test remains; from loc. $8 \mathrm{e}$.

\section{Description}

This large specimen is still septate at $132 \mathrm{~mm}$ diameter. The shell is inflated with slightly depressed ovate whorl section and moderately involute with a narrow, deep umbilicus. The round, steep umiblical wall curves in the highly arched venter. There is no sign of ornamentation on the last half-whorl, while the penultimate half-whorl has some faint lateral swellings and obsolescent broad ventral plications. The venter and a small part of the flank of the penultimate whorl, however, display evenly spaced, stout, blunt secondaries and the outer umbilical shoulder bears distant nodes (c. 5 per half-whorl) which change apicad into bullate primary costae. A blunt constriction is present at about $95 \mathrm{~mm}$ diameter, at the end of the penultimate phragmocone whorl. The test is thick. The septal suture is simple with broad shallow lobes of which the three to four umbilical lobes are somewhat oblique. The last several sutures are approximated.

\section{Remarks}

This species resembles the associated $G$. loupekinei more than any other known species of Gravesia but differs by the more compressed and involute whorls, by the weaker ornament, and by the slightly larger size. Since high whorl compression, tight coiling, and weak ornamentation are normally correlated in infraspecific variation (Westermann, 1969), this specimen may well be a variant or morph (forma) of $G$. loupekinei.

\section{Measurements}

$\begin{array}{lrrrrrr}\begin{array}{l}\text { SPECIMEN NO. } \\ \text { KNMI-MA50 }\end{array} & \mathrm{D} & \mathrm{U} & \mathrm{U} / \mathrm{D} \% & \mathrm{H} & \mathrm{W} & \mathrm{H} / \mathrm{W} \\ \text { end phragm. } & 132.0 & 33.5 & 25.3 & \text { c. } 55.0 & \text { c. } 60.0 & \text { c. } 0.90 \\ & 80.0 & 21.0 & 26.2 & 35.0 & 42.5 & 0.83\end{array}$

Family Aspidoceratidae Zittel, 1895

Subfamily Aspidoceratinae Zittel, 1895

Genus Aspidoceras Zittel, 1868

\section{Type Species}

Ammonites rogoznicensis Zeuschner, 1846.

Aspidoceras cf. A. acanthicum (Oppel, 1863) $q+?$ ?

PI. 14, figs. 1a-c; 2a,b; 3a,b 
?Ammonites acanthicus Oppel, 1863:219.

?Aspidoceras somalicum Dacqué, 1904:149, pl. XVII (IV), figs. 1a,b.

?Aspidoceras kilindinianum Dacqué, 1910:pl. I, fig. 9; pl. III, figs. 6a,b.

Acanthosphaerites pavlowi-Spath, 1925:118, pl. XV, figs. 1a,b.

Acanthosphaerites aff. longispinus-Spath, 1930a:58, pl. VII, fig. 6.

Aspidoceras aff. acanthicum-Spath, 1931:624, pl. CXXIII, fig. 7 (cum synonymy).

Aspidoceras acanthicum-Collignon, 1959, pl. CXXVIII, figs. 479, 480.

\section{Material}

Eleven specimens including one external mould. ROM 34795, phragmocone and partial body chamber; from loc. 8a. ROM 34796, external mould; ROM 34797 , KNMI-MA51-53, ROM 34799, ROM 34800, ROM 34801, ROM 34803, and ROM 34804, phragmocones with partial or complete body chambers; from loc. $8 \mathrm{~d}$. ROM 34820 , from "up to 650 yards east of . . . Port Tudor, 2-3/4 miles northeast of Changamwe Station and 2 miles northwest of junction of track to Nguu Tatu with main coast road" (British Petroleum-Shell Development Company). KNMI-MA52 and ROM 34801 are probable microconchs.

\section{Remarks}

This well-known European species of Aspidoceras named by Oppel, was first figured by Gemmellaro (1872). According to Spath (1931:625) the name A. acanthicus is " "meant for the fairly evolute and rather compressed forms with a continuous series of umbilical tubercles, but a far less regular and often disappearing outer row." The specimens before us fit this description entirely. In coiling, this species is very similar to A. longispinum (Sowerby, 1825) which, on account of the distortions in Sowerby's original line drawing, has been subject to differing interpretations by many authors. The holotype of $A$. longispinum, probably from the Eudoxus Zone, was recently refigured by Callomon and Cope (1971). A. longispinum differs in the rounded whorl section and in the presence of a regular outer row of tubercles forming the base of the spine.

The significance of these morphologic differences and, hence, the problem of true specific differences, however, remains obscure. Callomon (pers. comm., 2 May 1979) has no objection to our identification, but in his opinion, "the number of specific names in use under Aspidoceras is absurd, and most of the names define only morphological variants; the variability at any one level probably ranges over everything from forms with single to double rows of tubercles, on inner or outer whorls or both or neither, on involute or evolute shells; the value of these morphospecies for stratigraphical purposes is therefore close to zero." He suggests, therefore, that $A$. acanthicum, together with many others, may be a mere variant of a biospecies for which the oldest name would be A. longispinum (J. de C. Sowerby, 1825). Its holotype is "almost certainly Eudoxus Zone ...., i.e. above the Acanthicus Zone." B. Ziegler (pers. comm., 2 August 1978), on the other hand, believes that $A$. acanthicum belongs to a group of interrelated species (?or geographic subspecies), with the true acanthicum being distinguished from Mediterranean forms by the flattened flank. He considers it possible that our Kenyan form belongs to the Mediterranean taxon or taxa whose stratigraphic positions are poorly known.

Spath's (1930a) Kenyan "Acanthosphaerites aff. longispinum (Sowerby)" should therefore be attached to $A$. cf. acanthicum because of the absence of well-developed 
outer spines. Beyrich (1878) and Futterer (1894) recorded “Ammonites'” longispinus Sowerby in their collections from Mombasa. In the absence of illustrations and in view of the known differences between Sowerby's original line drawing of the holotype (1825:164, pl. 501, fig. 2) from the actual specimen, it appears that both authors were dealing with $A$. acanthicum or with the strongly bituberculate $A$. iphiceroides Waagen of which we have recovered abundant material (see below).

Dacqué (1910) included Beyrich's and Futterer's forms in the synonymy of $A$. iphiceroides. Spath had incorrectly used the junior synonym Acanthosphaerites Rollier, 1922 for Aspidoceras species described by him from Somalia (1925) and Mombasa (1930a). Later he transferred these species correctly to Aspidoceras in his Kachchh monograph (1931:617). Aspidoceras somalicum Dacqué is identical to $A$. acanthicum in whorl section, coiling, and distribution of the tubercles. Dacqués $A$. kilindinianum from Mombasa, judging from the figures, should also be included in $A$. acanthicum. We do not agree with Spath's placement of Dacqué's strongly bituberculate form in Physodoceras richthofeni (Müller). The Mexican "Acanthosphaerites" pavlowi (Burckhardt) according to Spath (1925:118) has "two rows of delicate tubercles on the inner whorls but only an inner row at the umbilical border of the outer whorl, whilst the outer row is reduced to a single tubercle." This description and the figure (pl. XV, figs. 1a,b) suggest strong affinity with $A$. acanthicum. "Aspidoceras" pavlowi Burckhardt (1912:77, pl. XIX, figs. 1-3, 5, 9) has an inwardly directed row of spines at the umbilical margin which suggests inclusion in the subgenus Pseudowaagenia Spath, 1931.

Specimen ROM 34820 (RGM 1888 from the British Petroleum-Shell Development Company's collection), which Arkell (in Linton and Maclean, 1955) had placed in Aspidoceras iphiceroides Waagen, does not show the outer row of tubercles and is therefore identified with $A$. acanthicum.

Our collection contains two probable microconchs (KNMI-MA52, ROM 34801) in which septation ceases at $46 \mathrm{~mm}$ and $57 \mathrm{~mm}$ diameter respectively, much earlier than in the corresponding macroconchs, for example, ROM 34800. Dimorphism is indicated by the identity of their inner whorls and their association.

\section{Stratigraphic Occurrence}

Rather abundant in the Hybonotum Zone.

\section{Measurements}

\begin{tabular}{lrrrrrr} 
SPECIMEN NO. & \multicolumn{1}{c}{$\mathrm{D}$} & $\mathrm{U}$ & $\mathrm{U} / \mathrm{D} \%$ & $\mathrm{H}$ & $\mathrm{W}$ & $\mathrm{H} / \mathrm{W}$ \\
ROM $34795(q)$ & c. 102.0 & 30.0 & 29.4 & c. 44.0 & c. 41.0 & 1.07 \\
ROM $34797(q)$ & c. 95.0 & 29.0 & 30.5 & 42.0 & c. 36.0 & 1.16 \\
KNMI-MA52 $(? \overrightarrow{)})$ & 50.0 & 12.5 & 25.0 & 23.5 & 27.0 & 0.87 \\
ROM $34799(q)$ & c. 82.0 & c. 22.0 & 26.8 & c. 35.0 & c. 34.0 & 1.02 \\
ROM 34800 (q) & 98.0 & 31.0 & 31.6 & 38.0 & 40.0 & 0.95 \\
ROM 34801 (?) & 67.0 & 19.0 & 28.3 & 27.0 & c. 28.0 & 0.96 \\
KNMI-MA51 & 109.0 & 29.0 & 26.6 & 52.0 & c. 54.0 & 0.96 \\
ROM 34804 & 74.0 & 19.0 & 25.6 & 20.9 & 35.0 & 0.82 \\
ROM 34803 $(q)$ & 95.0 & 28.0 & 29.4 & 40.0 & 40.0 & 1.00 \\
ROM 34820 $(q)$ & 87.0 & 24.0 & 27.5 & 40.0 & 43.0 & 0.93
\end{tabular}




\section{Aspidoceras aff. A. acanthicum (Oppel, 1863) \\ Pl. 15, fig. 1}

\section{Material}

One, possibly two specimens. KNMI-MA54, complete, left side damaged; from loc. 8k. ?ROM 34794, incomplete phragmocone; from loc. 8 b.

\section{Description}

The shell is planulate and evolute, with a slightly ovate whorl section including a highly arched venter. The umbilical wall is almost vertical. The phragmocone whorls bear a row of distant fine umbilical tubercles (four to five per half-whorl) but are otherwise smooth. On the last half-whorl of the body chamber, however, widely spaced mid-lateral nodes appear with increasing prominence, while the umbilical nodes fade except for a few irregular ones towards the aperture. Blunt primaries are also present. Rectiradiate growth lines are developed on at least the ultimate whorl.

\section{Remarks}

Our specimen KNMI-MA54 closely resembles Quenstedt's (1883-88, pl. 118, fig. 6) "Ammonites bispinosum" (= A. acanthicum) from the Weisser Jura Delta (Kimmeridgian) of southern Germany, except for the somewhat stronger reduction of the umbilical tubercles on the body chamber. Our $A$. acanthicum from the Hybonotum Zone has the lateral spines developed on the phragmocone and reduced on the body chamber. Other similar specimens were figured from Madagascar (Collignon, 1959, figs. 479, 480).

A. (Pseudowaagenia?) acanthomphalum (Zittel, 1870) from the Mediterranean has similar, probably septate whorls but differs in the more densely spaced tubercles. All other known species of the subgenus Pseudowaagenia are more compressed and usually lack the outer row of tubercles entirely (as far as known owing to usually incomplete preservation).

\section{Stratigraphic Occurrence}

Rare in the Kimmeridgian (Beckeri Zone +?).

\section{Measurements}

$\begin{array}{lrrrrrr}\begin{array}{l}\text { SPECIMEN NO. } \\ \text { KNMI-MA54 }\end{array} & \text { D } & \text { U } & \text { U/D\% } & \text { H } & \text { W } & \text { H/W } \\ \text { body ch. } & 128.0 & 44.0 & 34.3 & 48.0 & \text { c. } 44.0 & 1.09 \\ \text { end phragm. } & 80.0 & 22.5 & 28.0 & 34.5 & 33.2 & 1.03\end{array}$

Aspidoceras iphiceroides Waagen, $1875+\phi+\widehat{\sigma}$

Pl. 15, figs. 2; 3a,b; Pl. 16, figs. 1a,b; 2,3

Aspidoceras iphicerus-Zittel, 1870:75, pl. 30(6), fig. 1. [Non A. iphicerus Oppel]. Aspidoceras iphiceroides Waagen, 1875:102, pl. XXIII, figs. 1a, 2; Dacqué, 1910:24, pl. I, fig. 8; pl. IV, fig. 4; text-fig. 13 [cum synonymy]; Spath, 1931:635, pl. CXXIII, figs. 8a,b. 
Acanthosphaerites aff. iphiceroides-Spath, 1930a:60, pl. VII, figs. 1, 8 [cum synonymy].

Aspidoceras mombasense Spath, 1931:636 (for Spath, 1930a).

Aspidoceras cf. iphiceroides - Collignon, 1959, pl. CXXX, fig. 485.

\section{Material}

Twenty-three specimens of which 12 are complete phragmocones, some with partial body chambers. KNMI-MA55, well-preserved microconch with partial body chamber; from loc. 8a. ROM 34807 and 34808, whorl fragments; from loc. 8b. ROM 34810, whorl fragment; from loc. 8b1. ROM 34811, whorl fragment; from loc. 8c. ROM 34812 , whorl fragment of macroconch; ROM 34813, incomplete phragmocone; ROM 34814 , incomplete phragmocone of probable microconch; ROM 34815, whorl fragment; ROM 34816, well-preserved inner whorls; ROM 34817, whorl fragment; ROM 34818, macroconch with incomplete outer whorl; KNMI-MA56, complete microconch; KNMI-MA7734, complete macroconch; ROM 34821, macroconch whorl fragment; ROM 34822, whorl fragment; ROM 34823, macroconch with incomplete body chamber; all from loc. 8d. ROM 34826 and 34827, whorl fragments; KNMI-MA7733, macroconch with missing inner whorls; KNMI-MA57, complete phragmocone; and ROM 34830, whorl fragment; from loc. 8h. ROM 34829, incomplete microconch; KNMI-MA7735, fragment with spines, from loc. 8k.

\section{Remarks}

The present material has yielded complete large adult macroconchs and large body chamber fragments with a complete diameter of 240 to $280 \mathrm{~mm}$. KNMI-MA7734 (Pl. 15 , figs. $3 a, b)$ is the best preserved of the macroconchs with the body chamber occupying slightly more than half a whorl. The sculpture of the large body whorl is slightly modified. The tubercles become thicker, radially elongate, and the inner and outer tubercles are joined by ridgelike undulations near the aperture. The microconch has a complete adult diameter of only 107 to $160 \mathrm{~mm}$, approximately one-half of the macroconch.

The umbilical spines are often broken during the excavation of the umbilicus. In some specimelis, the matrix, removed in one piece, includes conical spines with rounded top (Pl. 16, fig. 2). On the middle whorls, the spines are about 5 to $6 \mathrm{~mm}$ across at the base and 8 to $10 \mathrm{~mm}$ high.

The septal suture is exposed in many of our specimens and resembles that shown by Waagen (1875, pl. XXIII, fig. 1c).

The species is easily identified from Waagen's original description and figure of the type specimen, as well as from Spath's additional remarks on this important Kachchh species. According to Spath (1931:635), "the characteristic features are the closeness of the two rows of tubercles on the septate whorls and the resulting extremely highly arched venter." He stated that Waagen's imperfect line drawing of the holotype was probably responsible for Dacqué's (1910) denial of an arched venter. The examination of our abundant new material supports Spath's statement (1931:636) that "the very highly arched venter is the most conspicuous feature of $A$. iphiceroides." The well-known European A. iphicerum (Oppel, 1863:222, pl. 60, figs. $2 \mathrm{a}, \mathrm{b})$ has a similarly arched venter and closely spaced double rows of equally strong tubercles, but differs in the prominent ridges connecting corresponding inner 
and outer tubercles. These ridges are missing in Zittel's (1870) Ammonites iphicerus Oppel, which is probably conspecific with $A$. iphiceroides, although the outer row of tubercles in Zittel's illustration is farther from the inner row than in Waagen's type.

In the original description of this species Waagen states $(1875: 102)$ that " $A$. iphiceroides is not very large, attaining scarcely more than $150 \mathrm{~mm}$ in diameter; the whorls are inflated, the umbilicus deep, the siphonal side prominent, broad, rounded .... The species does not seem to become very large, specimens of 150 to $180 \mathrm{~mm}$ diameter apparently are already full grown." The adult complete specimens recovered by us have identical inner whorls. In the microconchs septation ceases at about 110 to $120 \mathrm{~mm}$ diameter and in the macroconchs at about 210 to $220 \mathrm{~mm}$ diameter. Waagen's larger type specimen (1875, pl. XXIII, figs. 1a-c) belongs to the former size category. It is therefore highly likely that Waagen and Spath were dealing with the microconchs at Kachchh and Mombasa.

Spath, in his comments on A. iphiceroides from Kachchh (1931:635-36), stated that of his two specimens from Mombasa $(1930 \mathrm{a}$, pl. VII, figs. 1,8$)$ the smaller one (fig. 8) is more.strongly tuberculate than the typical $A$. iphiceroides and should be separated; he created the new name $A$. mombasense for this form. Our material of $A$. iphiceroides indicates intraspecific variation in the strength of the tubercles, and includes many specimens with identical tuberculation as in Spath's " $A$. mombasense". We therefore do not believe that the new name was warranted.

\section{Stratigraphic Occurrence}

Abundant in the Beckeri and Hybonotum Zones.

\section{Measurements}

\begin{tabular}{|c|c|c|c|c|c|c|}
\hline SPECIMEN NO. & $\mathrm{D}$ & $\mathrm{U}$ & $\mathrm{U} / \mathrm{D} \%$ & $\mathrm{H}$ & W & $\mathrm{H} / \mathrm{W}$ \\
\hline KNMI-MA55 ( ఏే) & 133.5 & 37.5 & 28.0 & 61.0 & 65.0 & 0.93 \\
\hline ROM 34829 (తో) & 123.0 & 35.5 & 28.8 & 47.0 & 67.0 & 0.70 \\
\hline KNMI-MA56 (ð) & 159.0 & 53.0 & 33.3 & 62.0 & 74.5 & 0.83 \\
\hline KNMI-MA7734 ( q) & 278.0 & 112.0 & 40.3 & 100.0 & 110.0 & 0.90 \\
\hline ROM 34823 (ㅇ) & 190.0 & 57.0 & 30.0 & 79.0 & 109.0 & 0.72 \\
\hline KNMI-MA7733 (ㅇ) & 240.0 & 100.0 & 41.6 & 88.0 & c. 110.0 & 0.80 \\
\hline
\end{tabular}

\section{Aspidoceras cf. A. iphicerum (Oppel, 1863)}

Pl. 16, figs. 4,5

\section{Material}

Three somewhat crushed internal moulds, KNMI-MA57a, with part of body chamber; from loc. 8a. KNMI-MA57b, septate fragment; from loc. 8k. KNMI-MA57c, septate fragment; from loc. $8 \mathrm{~h}$.

\section{Remarks}

The large, widely umbilicate, almost planulate shell has a well-rounded venter. The regular, moderately dense, bituberculate ornament has the outer nodes placed slightly above mid-flank and the inner ones on the umbilical margin. Conellae on the nodes indicate the original presence of hollow-floored spines of which the inner one probably projected obliquely into the umbilicus. The nodes are connected by blunt undulations. 
Although the modest state of preservation does not permit specific identification, there is close resemblance to Aspidoceras iphicerum (Oppel, 1863, pl. 60, figs. 2a,b) originally described from the Swabian Jura. Collignon (1959, fig. 490) figured a probable example of this species from the Lower Tithonian of Madagascar.

A very similar, if not identical, species is $A$. bispinosum (Zieten) as figured by Quenstedt (1883-88, pl. 118, figs. 1-5 only) from the Kimmeridgian (proper) of southern Germany. It appears to differ from $A$. iphicerum only in the weaker nodes (and spines) and the obsolete plications between them.

\section{Stratigraphic Occurrence}

Rare in Kimmeridgian to basal Hybonotum Zone.

Measurements

$\begin{array}{lccccc}\text { SPECIMEN NO. } & \text { D } & \text { U } & \text { U/D\% } & \text { H } & \text { W } \\ \text { KNMI-MA57a } & 159.0 & 61.0 & 38.3 & \text { c. } 53.0 & \text { c. } 60.0\end{array}$

Aspidoceras cf. A. appenninicum Zittel (1869) 1870

Pl. 17, figs. 1a,b

\section{Material}

One specimen. KNMI-MA58, partly crushed large phragmocone without inner whorls, mostly internal mould; from loc. $8 \mathrm{~h}$.

\section{Remarks}

The inner whorls up to $35 \mathrm{~mm}$ diameter are unknown. The penultimate septate whorl is somewhat broader than high and well rounded between the nodes, while the outer whorl becomes slightly compressed. The venter is broadly and evenly rounded. The ornament consists of a double line of thick and prominent nodes. The outer (ventrolateral) nodes are more prominent, sometimes slightly clavate and still partially capped by the floors of hollow spines. The inner and outer nodes are connected by incipient low ridges only. The narrow venter at the probable end of the phragmocone bears very blunt, irregular, and forward-convex secondaries.

The presence of nodes or spines at least on the inner whorls and a flat to concave venter with projecting spines distinguish Euaspidoceras (Epaspidoceras) spp. from France (d'Orbigny, 1842-51, pl. 205, figs. 1-3), Kachchh (Waagen, 1875, pl. 21, fig. 1), and Madagascar (Collignon, 1959, fig. 493).

Zittel's species, originally described from the Tithonian of Italy (1870, pl. 29, figs. $6 \mathrm{a}-\mathrm{c})$, has apparently not yet been recorded from the Indo-Southwest Pacific Province. Our specimen appears to be a good match, except for its larger size and unknown body chamber.

The "Aspidoceras haynaldi Herb. var. tuberculata" Collignon (1959, fig. 487) from the Lower Tithonian of Madagascar may be identical to this species. $A$. apenninicum has recently been recorded from the Beckeri Zone of Spain (Enay and Geyssant, 1975:41).

\section{Stratigraphic Occurrence}

Rare in Beckeri Zone. 
Measurments

$\begin{array}{lcccccc}\text { SPECIMEN NO. } & \mathrm{D} & \mathrm{U} & \mathrm{U} / \mathrm{D} \% & \mathrm{H} & \mathrm{W} & \mathrm{H} / \mathrm{W} \\ \text { KNMI-MA58 } & 136.0 & 59.0 & 43.3 & 48.0 & 41.0 & 1.17\end{array}$

\section{Subgenus Physodoceras Hyatt, 1900}

\section{Type Species}

Ammonites circumspinosus Quenstedt, 1858.

\section{Aspidoceras (Physodoceras) cf. A. avellanum Zittel, 1870 P1. 17, figs. 2a,b}

?Acanthosphaerites deaki-Spath, 1930a:60, pl. 8, figs. 3?, 5, 6 (non Herbich).

\section{Material}

Seven internal moulds with test remains. ROM 34835, partial body chamber with imperfectly preserved inner whorls; from loc. 8c. KNMI-MA59, phragmocone; from loc. 8 d. ROM 34836, complete specimen with phragmocone and body chamber with damaged umbilical area; ROM 34837, part of body chamber and inner whorls; and KNMI-MA7736, complete specimen with slightly damaged phragmocone; from loc. 8e. ROM 34839, incomplete body chamber; from loc. 15c. ROM 34838 (RGM 1890), body chamber; from "just under 2 miles north-north-west of junction of track to Nguu Tatu and main coast road and about 350 yards west of track" (together with Gravesia loupekinei).

\section{Description}

The shell is globose, highly inflated with depressed elliptical whorls and a narrow deep umbilicus which enlarges rapidly and early with the last septate half-whorl, resulting in elliptic coiling. The umbilical wall is rounded, vertical to overhanging. The flanks and venter are evenly convex. The phragmocone terminates at about $85 \mathrm{~mm}$ diameter and the body chamber occupies a little more than half a whorl. The umbilical margin carries a series of tubercles which become more prominent with growth. Excavation of the umbilicus in some of the specimens revealed inwardly directed spines on the tubercles. The tubercles of the last whorl become blunt and more widely spaced, but may also have carried spines. Some specimens have faint radial striations on the outer part of the shell which usually is entirely smooth. The septal suture has a relatively narrow and deep external lobe E, a broad external saddle, a moderately broad (first) lateral lobe L, about as deep as the external lobe, and a moderately deep second umbilical ("second lateral") lobe.

\section{Remarks}

This species is characterized by the depressed whorl section, elliptic coiling, and inclined umbilical nodes which carried spines at least on the inner whorls. The radial folds and prominent persistent lateral spines of the subgenus Orthaspidoceras, however, are missing. "Acanthosphaerites deaki (Herbich)", figured by Spath 
(1930a, pl. 8, figs. 3, 5,6), and said to be more involute and less compressed than Herbich's type, resembles this species, although the inwardly directed spines are not clearly visible in Spath's illustrations. The best comparison is probably with the large syntype of $A$. avellanum Zittel (1870:86, pl. 7(31), figs. 3a,b at centre) from the Lower Tithonian of Monte Catria in Italy. This type specimen probably has only half its body chamber, but appears to be damaged since its whorl width was not given. This species has recently been recorded from the Hybonotum Zone of southeastern Spain (Enay and Geyssant, 1975:41). A similar species is A. (Physodoceras?) pinini (Oppel, 1863:257, pl. 72, figs. 3a-e) from the early Tithonian Solnhofen Limestone. Its persistent, laterally directly spines, however, indicate a transitory position towards A. (Orthaspidoceras). A. supraspinosum Dacqué (1904, pl. 16, figs. 2a, b) from Somalia differs in the larger number of spines modified into bullae.

\section{Stratigraphic Occurrence}

Moderately abundant in the Hybonotum Zone.

\section{Measurements}

$\begin{array}{lrrrrrr}\text { SPECIMEN NO. } & \mathrm{D} & \mathrm{U} & \mathrm{U} / \mathrm{D} \% & \mathrm{H} & \mathrm{W} & \mathrm{H} / \mathrm{W} \\ \begin{array}{c}\text { KNMI-MA59 } \\ \text { ROM } 34837\end{array} & 77.0 & 21.0 & 27.2 & 35.0 & 46.0 & 0.76 \\ \begin{array}{c}\text { body ch. } \\ \text { phragm. }\end{array} & 134.0 & 42.0 & 31.0 & 51.0 & 71.0 & 0.71 \\ \begin{array}{c}\text { KNMI-MA7736 } \\ \text { body ch. }\end{array} & \text { c. } 76.0 & 9.0 & \text { c. } 12.0 & 31.0 & 46.5 & 0.67 \\ \begin{array}{c}\text { phragm. } \\ \text { ROM } 34836\end{array} & 120.0 & 32.0 & 26.6 & 48.5 & 67.0 & 0.72 \\ \begin{array}{c}\text { body ch. } \\ \text { ROM 34839 }\end{array} & \text { c. } 65.0 & 11.5 & \text { c. } 18.0 & 33.0 & \text { c. } 41.0 & \text { c. } 0.80 \\ \text { body ch. } & 135.0 & 35.0 & 25.9 & \text { c. } 60.0 & \text { c. } 71.0 & 0.84 \\ & 120.0 & 39.0 & 32.5 & 48.0 & 60.0 & 0.80\end{array}$

Aspidoceras (Physodoceras) circumspinosum (Quenstedt, 1858)

Pl. 17, figs. $3 a, b$

Ammonites circumspinosus Quenstedt, 1858:609.

Ammonites inflatus macrocephalus Quenstedt, 1883-88:1018, pl. 116, figs. 6, 9 [holotype], 16, 17.

?Physodoceras cf. circumspinosum-Collignon, 1959, pl. 110, fig. 407.

\section{Material}

Three specimens from loc. 8e. KNMI-MA60, well-preserved phragmocone with partially preserved umbilical spines; ROM 34828 , laterally crushed phragmocone with damaged umbilical spines; ROM 34809, large undistorted phragmocone with spines embedded in umbilical matrix.

\section{Description}

The shell is of medium size, involute and globose, with depressed whorl section. The umbilical wall is steep and rounded and carries at the margin closely spaced sharp 
spines which are directed inwards. The flanks are gently curved and the venter broadly rounded. The suture has a narrow, moderately deep external lobe, a broad external saddle, a lateral lobe as deep as the external lobe, a thin and deeply second umbilical lobe, and two to three smaller umbilical lobes.

\section{Remarks}

This well-known European species is recorded from Kenya for the first time. It is unknown from Kachchh, but a doubtful immature example from Madagascar was figured by Collignon (1959).

\section{Stratigraphic Occurrence}

Rather rare in the Hybonotum Zone.

\section{Measurements}

\begin{tabular}{llrrrrr} 
SPECIMEN NO. & D & \multicolumn{1}{c}{ U } & U/D\% & H & W & H/W \\
KNMI-MA60 & 54.0 & 5.0 & 9.2 & 28.0 & 39.0 & 0.71 \\
ROM 34828 & c. 49.0 & c. 5.0 & 10.2 & c. 25.0 & c. 37.0 & 0.67 \\
ROM 34809 & 89.0 & c. 15.0 & 16.8 & 40.0 & 56.0 & 0.71
\end{tabular}

Family Simoceratidae Spath, 1924

Genus Hybonoticeras Breistoffer, 1947

\section{Type Species}

Ammonites hybonotus Oppel, 1863.

\section{Hybonoticeras hybonotum (Oppel, 1863)}

Pl. 18, figs. 1a-d; Pl. 19, fig. 2. Text-fig. 11

Ammonites hybonotus Oppel, 1863:254, figs. 1-3.

?Ammonites hildebrandti Beyrich, 1877:101.

?Waagenia hildebrandti-Futterer, 1894:6, pl. III, figs. 1, 1a, 2, 2a.

?Hybonoticeras hildebrandti-Spath, 1931:647.

Hybonoticeras hybonotum-Berckhemer and Hölder, 1959:30, pl. 3, fig. 12; pl. 5,

figs. 18, 19; text-figs. 16-18 [cum synonymy]; Barthel, 1959: 63, figs. 7a,c;

Sapunov, 1977:47, pl. 1, fig. 1.

?Hybonoticeras hybonotum - Collignon, 1959, pl. CXXXII, fig. 494.

\section{Material}

Two specimens. KNMI-MA61a, well-preserved phragmocone with part of body chamber; from loc. 8a. KNMI-MA61b, part of body chamber; from loc. 8c.

\section{Description}

The shell is medium to large, evolute, compressed platycone with subrectangular whorl section. The umbilicus is wide and shallow with moderately steep slope. The 
whorl sides are subparallel and the venter is deeply sulcate, flanked by two serrated ridges. The ornament consists of two rows of tubercles, one just above the umbilical margin and the other at the ventro-lateral shoulder, and faint ridges connecting the inner and outer tubercles. The umbilical tubercles are thinner than the ventro-lateral ones and stand perpendicular to the symmetry plane whereas the ventro-lateral tubercles are inclined. There are approximately three serrations to every ventro-lateral tubercle. The septal suture is asymmetric with the median saddle of the external lobe located at the crest of the right-hand ventral ridge. The suture (Text-fig. 11) is typical of the Aspidoceratidae and consists of a deep external lobe $\mathrm{E}$, a very broad external saddle containing three accessory lobes, a deep lateral lobe $\mathrm{L}$, and a second umbilical lobe $\mathrm{U}_{2}$ about half as deep as the lateral lobe.

\section{Remarks}

A poorly preserved cast from Mombasa was originally described by Spath (1930a) as $H$. aff. hybonota, but later named $H$. kachhense (Spath, 1931:645, 647). As far as we know, the present specimens are the first good evidence for the occurrence of $H$. hybonotum, important zonal index, from East Africa, although it may occur in Madagascar (Collignon, 1959). " $H$. hildebrandti" (Beyrich) Futterer, the only previously described Hybonoticeras from East Africa, was based on one or two fragments only. According to Futterer's cross section, the nodes are much more prominent and the ribs weaker than in his drawing of the lateral view. $H$. hildebrandti is therefore tentatively included in $H$. hybonotum. The species is closely related to $H$. kachhense which has more distinct outer tubercles.

\section{Stratigraphic Occurrence}

Hybonotum Zone.

\section{Measurements}

$\begin{array}{lcccccc}\text { SPECIMEN NO. } & \mathrm{D} & \mathrm{U} & \mathrm{U} / \mathrm{D} \% & \mathrm{H} & \mathrm{W} & \mathrm{H} / \mathrm{W} \\ \text { KNMI-MA61a } & 121.0 & 50.5 & 41.0 & 42.0 & 28.0 & 1.50\end{array}$

\section{Hybonoticeras cf. H. hybonotum (Oppel, 1863)}

Pl. 18, figs. $2 a, b$

?Waagenia cf. hildebrandti-Spath, 1930a:62, text-fig. 4c.

\section{Material}

Two specimens, whorl fragments mostly of body chambers. ROM 34844, and KNMI-MA61c; from locs. 8d and 8j respectively.

\section{Remarks}

This would perhaps also include the fragment recorded by Spath (1930a) from the Kimmeridgian “'(Middle) Coroa Mombasa”' near Freretown.

Hybonoticeras cf. H. ornatum (Spath, 1931)

Pl. 19, figs. 3, 4 


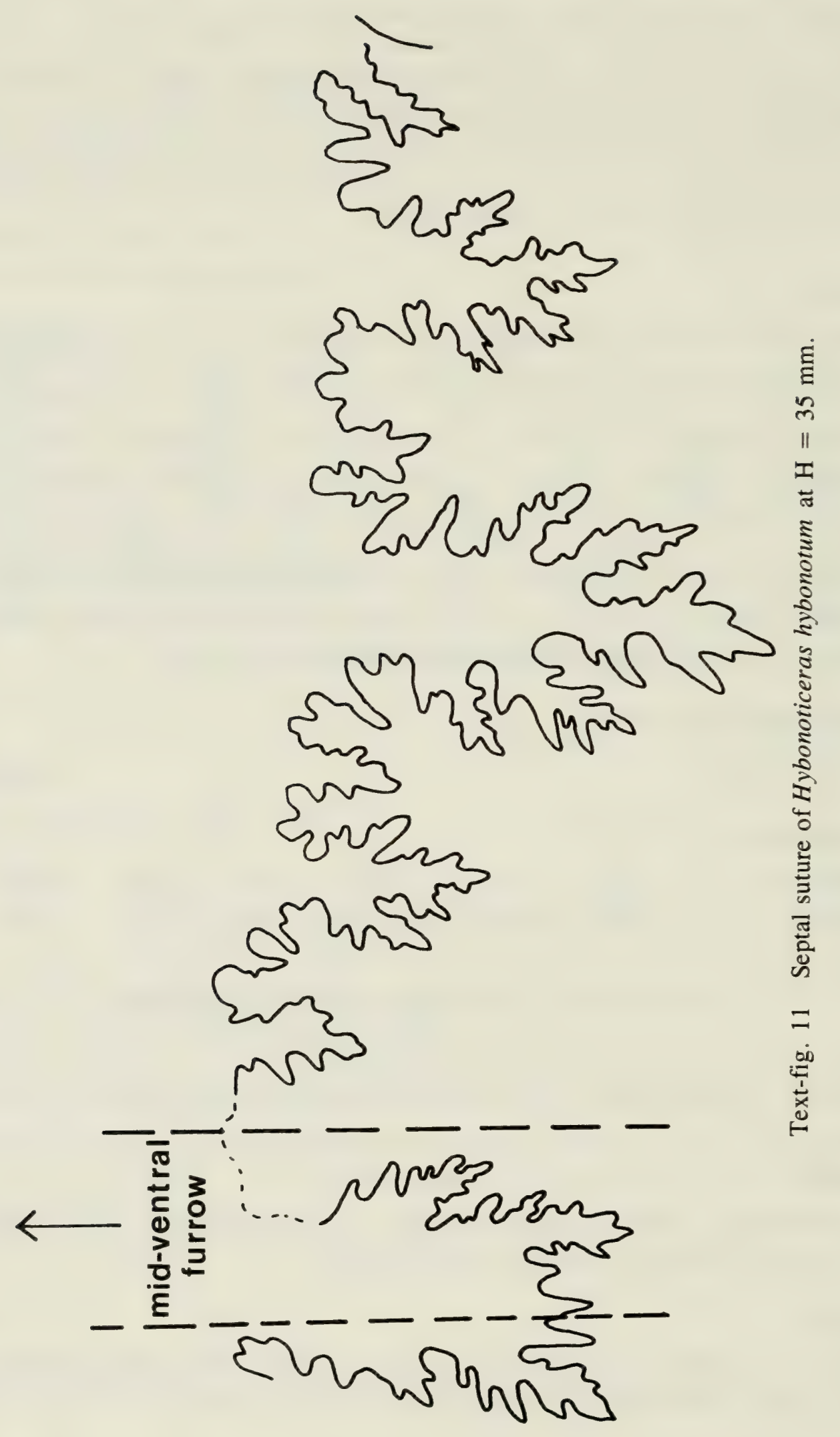


(?)Waagenia sp. nov. Spath, 1930a:62, text-figs. 4a and b only.

(?)Waagenia ornata Spath, 1931:649, pl. CXVIII, fig. 5; pl. CXX, figs. 1a,b

[holotype].

(?)Waagenia africana Spath, 1931:650 [for Spath, 1930a].

\section{New Material}

Two crushed fragments of body chamber internal moulds. KNMI-MA62a,b; from loc. 8 a.

\section{Remarks}

The ornate body chamber fragment from Mombasa, which Spath (1930a) described as "Waagenia" sp. nov., was later renamed by him "Waagenia" africana Spath (1931) in his Kachchh monograph. The fragment was said to be closely related to "W." ornata from the lower and middle Katrol Group of Kachchh (Beckeri and Hybonotum Zones) and appears to be conspecific. $H$. ornatum is characterized by massive subquadrate whorls and much coarser ornamentation than in $H$. beckeri, a species also occurring in the lower Katrol Group.

The fragments in our collection resemble the holotype of $H$. ornatum. The thick umbilical tubercles give rise to pairs of ribs. These converge in ventro-lateral tubercles which are elongated ventrally into faint rursiradiate ridges. The small serrations on the ventral ridges are also rursiradiate.

$H$. ornatum was tentatively regarded as a subspecies of $H$. beckeri (Neumayr) by Berckhemer and Hölder (1959:28). The two nominal forms may well be distinct species, however, with different stratigraphic ranges, $H$. ornatum ranging above $H$. beckeri.

Berckhemer and Hölder's ' $H$. beckeri extraspinatum', based on a fragment from near the zonal boundary of the Beckeri and Hybonotum Zones of southern Germany, is similar except for the reduced ventral spines of the outer whorl. A small fragment of dubious affinity was also illustrated from Madagascar (Collignon, 1959, pl. 106, fig. 392). These forms are perhaps phyletically and temporally transitional between $H$. beckeri and $H$. hybonotum.

\section{Stratigraphic Occurrence}

Rare in the basal Hybonotum Zone.

\section{Hybonoticeras pressulum (Neumayr, 1873)}

\section{Pl. 19, fig. 1}

Aspidoceras pressulum Neumayr, 1873:201, pl. 37, figs. 2, 3; fig. 3.

?Hybonoticeras breistofferi Collignon, 1959, pl. 132, figs. 497, 498.

Hybonoticeras pressulum-Berckhemer and Hölder, 1959:20, pl. 1, fig. 1; pl. 2,

figs. 6, 8; text-fig. 2 [cum synonymy; lectotype des.: Neumayr, 1873, fig. 3].

\section{Material}

Two to three specimens. KNMI-MA63a, complete specimen well preserved on one side, crushed on the other, inner whorls obscured; from loc. 8h. ROM 34847 , incomplete phragmocone; from loc. 8 b. ?ROM 34843 , body chamber fragment; from loc. 8 a. 


\title{
Description
}

The shell is medium large, highly compressed, and evolute. The umbilicus is wide and shallow and the umbilical wall steep and curved. The whorl section is compressed and rectangular, with large parallel flanks. The sharply curved venter has a moderately deep groove flanked by blunt ridges. The umbilical shoulder bears closely spaced, thin tubercles whose spacing and thickness increase with growth, but which become thinner and more pointed on the body chamber. Ventro-lateral tubercles appear to be missing, at least on the outer whorls; they may be present on the inner whorls. The septal suture is identical to that of $H$. hybonotum except for the somewhat deeper lateral and second umbilical lobes.

\section{Remarks}

This species is well known from Europe, especially from the upper Weisser Jura of southern Germany; it is here recorded from Kenya for the first time. Hybonoticeras breistofferi Collignon from the Hybonotum Zone of Madagascar may be identical with this species; it has sporadic ventro-lateral tubercles on the middle whorls whereas in $H$. pressulum these are developed on the early whorls. $H$. pressulum as described is clearly a macroconch, and a number of microconchs bearing lappets are also known (cf. Berckhemer and Hölder, 1959:34). The lectotype of $H$. beckeri (Neumayr) is only $55 \mathrm{~mm}$ in diameter and either a juvenile macroconch or a microconch. $H$. pressulum is, however, an excellent indicator of the Beckeri Zone and appears to be restricted to its lower part in Europe (Zeiss, pers. comm.).

\section{Stratigraphic Occurrence}

Beckeri Zone.

\section{Measurements}

$\begin{array}{lrccccr}\text { SPECIMEN NO. } & \mathrm{D} & \mathrm{U} & \mathrm{U} / \mathrm{D} \% & \mathrm{H} & \mathrm{W} & \mathrm{H} / \mathrm{W} \\ \text { KNMI-MA63a } & 141.0 & 73.0 & 51.7 & 42.0 & 22.0 & 1.90 \\ \text { ROM } 34847 & 90.0 & 39.0 & 43.3 & 31.5 & 15.0 & 2.10\end{array}$

\section{Hybonoticeras cf. $\boldsymbol{H}$. ciliatum Berckhemer and Hölder, 1959}

\author{
Pl. 19, fig. 5
}

\section{Material}

One specimen. KNMI-MA63b, complete specimen, well preserved on one side with exposed inner whorls; from loc. $8 \mathrm{c}$.

\section{Description}

The shell is medium large, evolute, and platyconic with a wide and shallow umbilicus. The umbilical walls are steep and rounded. The flanks are flat, subparallel, and the venter is narrowly rounded with a shallow median groove bordered by serrated ridges. The inner whorls have faint sinuous striations which probably persisted throughout growth; they are also visible in the apertural region. The umbilical margin carries thin, somewhat irregularly placed tubercles which on the nucleus develop from closely spaced rursiradiate ridges. Similar but thinner 
tubercles are present just below the ventro-lateral shoulder. Some of these outer tubercles continue into faint prorsiradiate ridges. The ventral groove is deep in the early growth stages but becomes shallow on the body chamber. Coarse rursiradiate serrations are present on the ventro-lateral ridges. The septal suture is similar to other Hybonoticeras but has a much deeper and thinner lateral lobe $\mathrm{L}$.

\section{Remarks}

This species is characterized by the sinuous striations, the thin and widely spaced umbilical and ventro-lateral tubercles, and a shallow mid-ventral groove. Our specimen differs from Hybonoticeras ciliatum only in the absence of the faint ridges connecting the inner and outer tubercles.

\section{Stratigraphic Occurrence}

Lower Hybonotum Zone.

\section{Measurements}

$\begin{array}{lcccccc}\text { SPECIMEN NO. } & \mathrm{D} & \mathrm{U} & \mathrm{U} / \mathrm{D} \% & \mathrm{H} & \mathrm{W} & \mathrm{H} / \mathrm{W} \\ \text { KNMI-MA63b } & 158.0 & 74.0 & 46.8 & 44.0 & \text { c. } 25.0 & 1.76\end{array}$

\section{Acknowledgements}

We would like to thank Professor Igor S. Loupekine of the Geology Department, University of Nairobi for much essential help with our project and, indeed, for making this project possible by arranging the guest professorship of Dr. G. E. G. Westermann.

Mr. K. B. Mungai, Permanent Secretary of the Office of the President, Government of Kenya, granted permission to conduct the field work (ADM.13/001/C855/10; 1972).

We would also like to thank Dr. Jean Mills Westermann who helped in the field with work under difficult climatic conditions, and Dr. J. Walsh, Chief Geologist of the Ministry of Natural Resources, Nairobi.

We wish to acknowledge the assistance of the directors of the Bamburi Portland Cement Works who allowed us to enter their property, particularly the New Mto Panga Quarry and surrounding area, and of the British Petroleum-Shell Development Company of Kenya who loaned us important fossil collections made by their geologists R. E. Linton, R. G. Maclean, and D. Haw.

We have discussed taxonomic and stratigraphic problems with Dr. R. Enay (Lyon), Dr. J. H. Callomon (London), Dr. B. Ziegler (Stuttgart), and Dr. A. Zeiss (Erlangen). Important type specimens and reproductions were kindly furnished by Dr. H. Jaeger and Dr. J. Helms of the Museum für Naturkunde der HumboldtUniversität, East Berlin.

At the Royal Ontario Museum we extend our most sincere thanks to Dr. D. H. Collins and Dr. Peter H. von Bitter of the Department of Invertebrate Palaeontology for facilitating this study; to Miss Joan Burke for typing parts of the manuscript; and to Mrs. Janet Waddington for assistance in curatorial services. 


\section{Plates}

Plate 1, figs. 1-3

1 Phylloceras isotypum Benecke

Changamwe Shale; Hybonotum Zone, Lower Tithonian. Undistorted phragmocone, lateral (a,b) and apertural (c) views KNMI-MA23. Loc. 8a, New Mto Panga Quarry, north of Freretown, Mombasa area.

2 Calliphylloceras benacense (Catullo)

Changamwe Shale, Hybonotum Zone; Lower Tithonian. Phragmocone with constriction and septal sutures, lateral view KNMI-MA24. Loc. 8c, New Mto Panga Quarry, north of Freretown, Mombasa area.

3 Calliphylloceras aff. C. malayanum (Boehm)

Changamwe Shale, Beckeri Zone; Upper Kimmeridgian. Incomplete phragmocone, lateral (a) and apertural (b) views, sutures (c) KNMI-MA25. Loc. 8b, north of Freretown, Mombasa area.

Scale for all figures equals $1 \mathrm{~cm}$. 

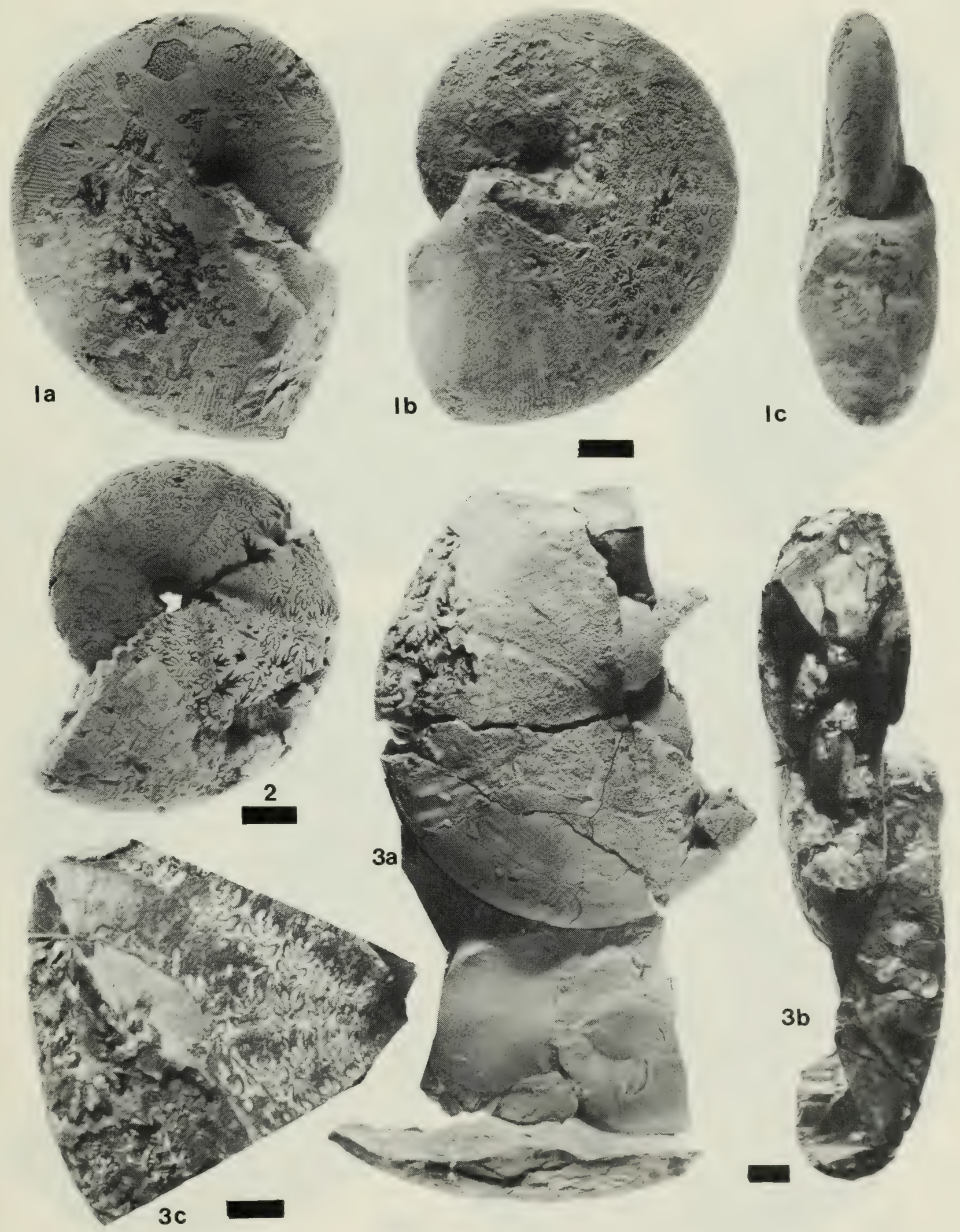
Plate 2, figs. 1-3

1 Ptychophylloceras ptychoicum (Quenstedt)

Changamwe Shale; Beckeri/Hybonotum Zones, Upper Kimmeridgian/Lower Tithonian. Phragmocone and body chamber, apertural (a) and lateral (b) views. ROM 34602. Loc. east shore of Port Tudor, 2.75 miles north-west of Changamwe Station and 2 miles north-west of junction of track to Nguu Tatu with main coast road.

2 Lytoceras fraasi Dacqué

Changamwe Shale, Beckeri/Hybonotum Zones; Upper Kimmeridgian/Lower Tithonian. Phragmocone with body chamber, inner whorls missing, lateral view KNMI-MA28. Loc. 15b, Changamwe Peninsula, Kipevu, northeast corner of Port Reitz.

3 Pterolytoceras montanum (Oppel)

Changamwe Shale, Hybonotum Zone; Lower Tithonian. External mould with protoconch (a), and part of the internal mould of crushed body chamber, lateral view (b) KNMI-MA29. Loc. 8d, New Mto Panga Quarry, Mombasa area.

Scale for all figures equals $1 \mathrm{~cm}$. 


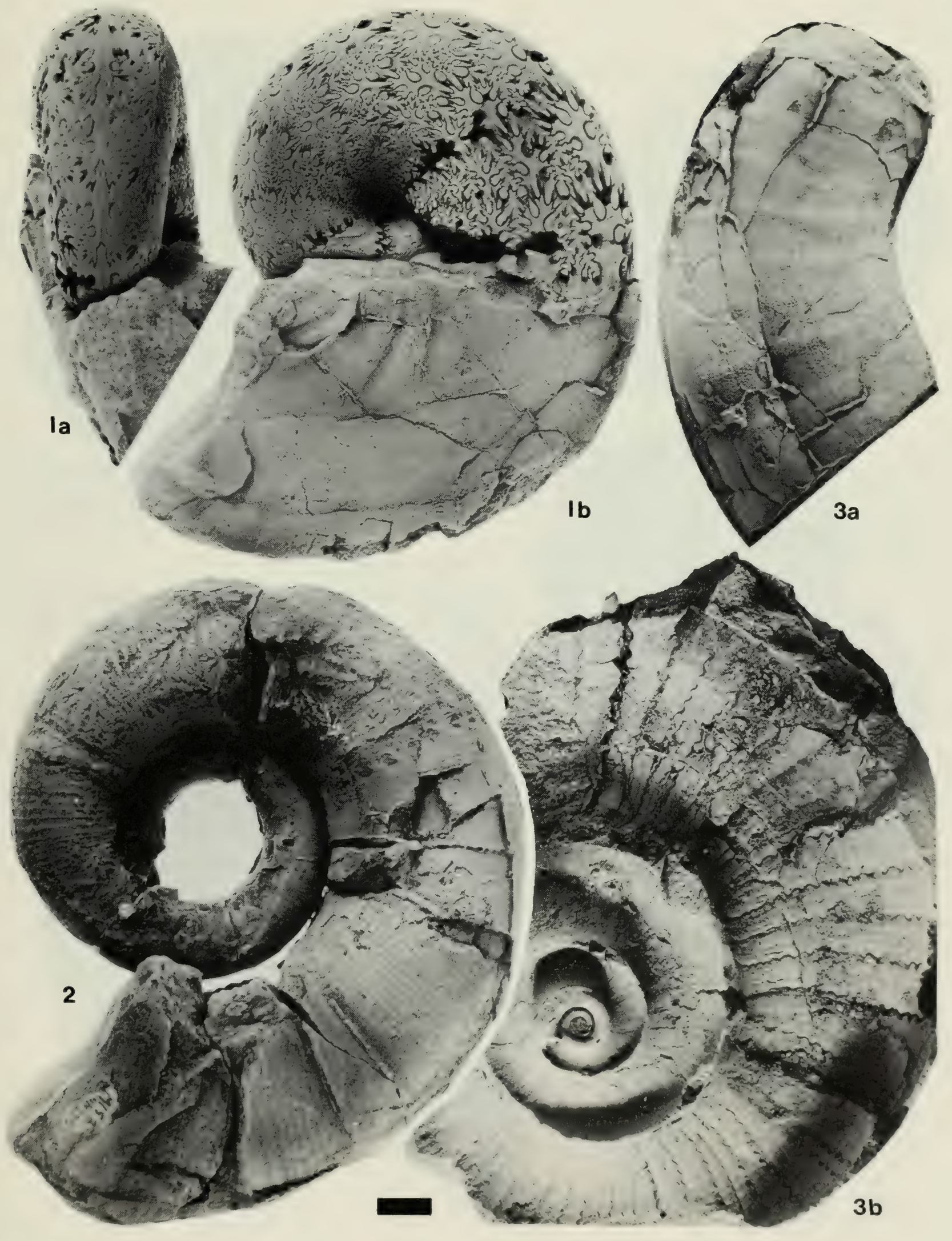


Plate 3, figs. 1-3

1 Taramelliceras (Taramelliceras) cf. T. kachhense (Waagen)

Changamwe Shale, Hybonotum Zone; Lower Tithonian. Phragmocone and body chamber well preserved on one side, lateral (a) and ventral (b) views KNMI-MA30. Loc. 8d, New Mto Panga Quarry, Mombasa area.

2 Taramelliceras (Taramelliceras) trachynotum (Oppel)? Changamwe Shale, Beckeri Zone; Upper Kimmeridgian. Body chamber fragment, lateral (a) and ventral (b) views KNMI-MA31. Loc. 8h, New Mto Panga Quarry, Mombasa area.

3 Streblites habyensis Spath

Changamwe Shale, Hybonotum Zone; Lower Tithonian. Complete specimen with partially crushed body chamber, lateral (a,b), ventral (c), and apertural (d) views KNMI-MA32. Loc. 8d, New Mto Panga Quarry, Mombasa area.

Scale for all figures equals $1 \mathrm{~cm}$. 


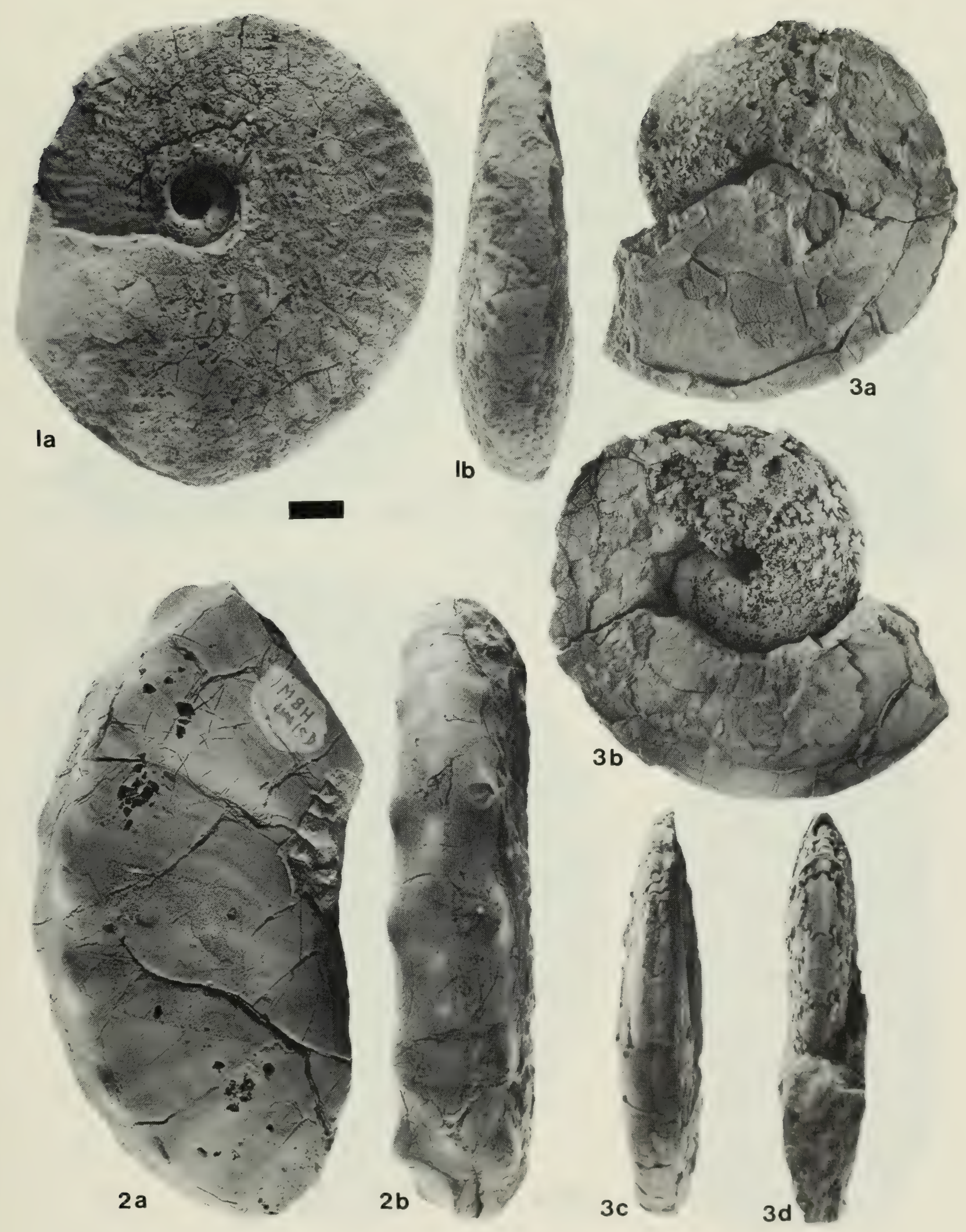


Plate 4, figs. 1-2

1 Katroliceras pottingeri (Sowerby)

Changamwe Shale, Beckeri Zone; Upper Kimmeridgian. Phragmocone with body chamber, lateral (a) and ventral (b) views KNMI-MA37. Loc. 8h, New Mto Panga Quarry, Mombasa area.

2 Katroliceras aff. $K$. pottingeri (Sow.) $)+$

Changamwe Shale. Hybonotum Zone; Lower Tithonian. Nearly complete with partially crushed body chamber, lateral (a), apertural (b), and ventral (c) views KNMI-MA38. Loc. 8c, New Mto Panga Quarry, Mombasa area.

Scale for all figures equals $1 \mathrm{~cm}$. 

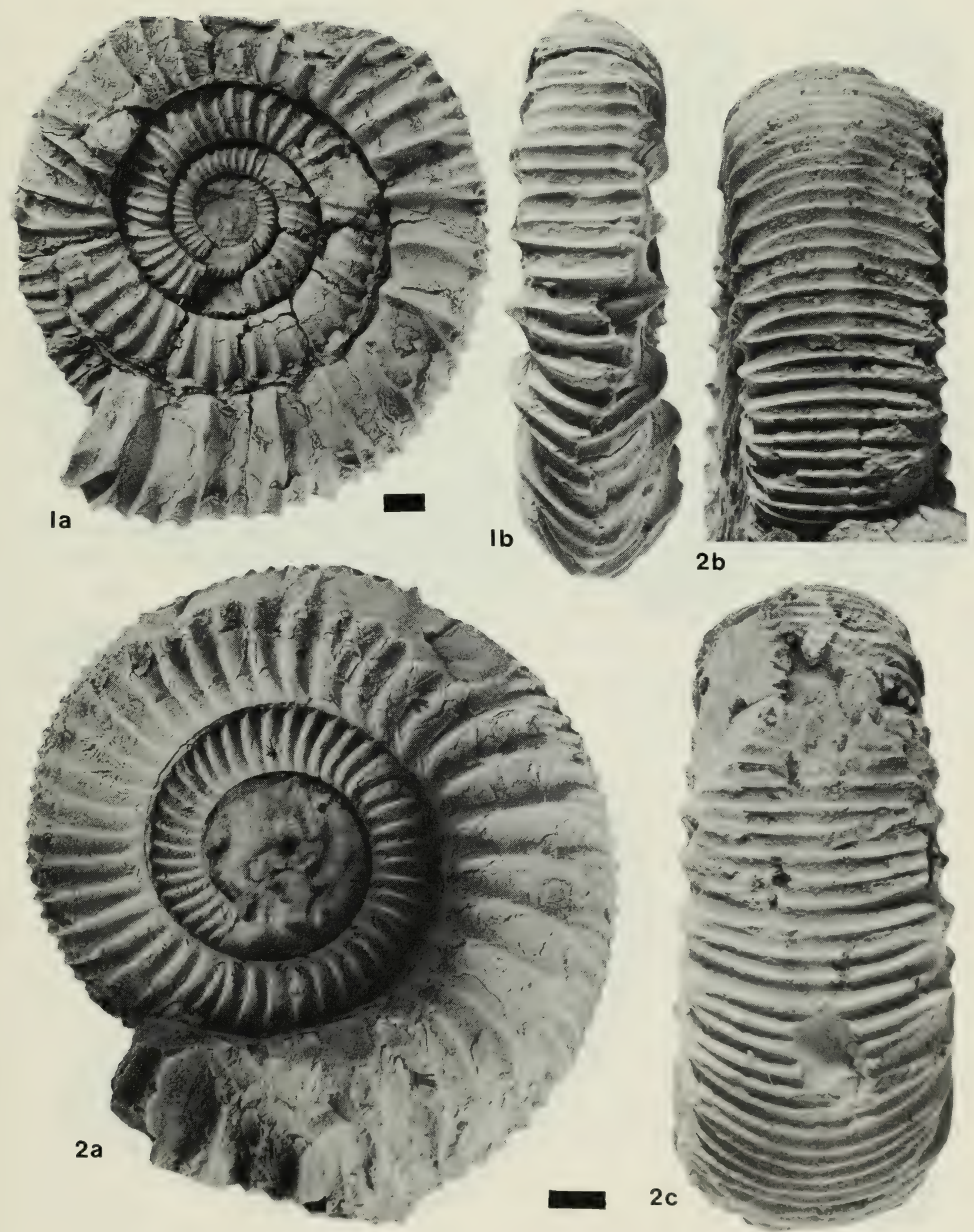

$2 b$
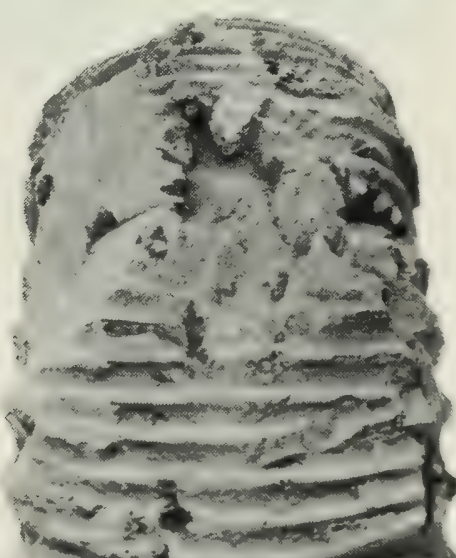

$15=$ is 2 -
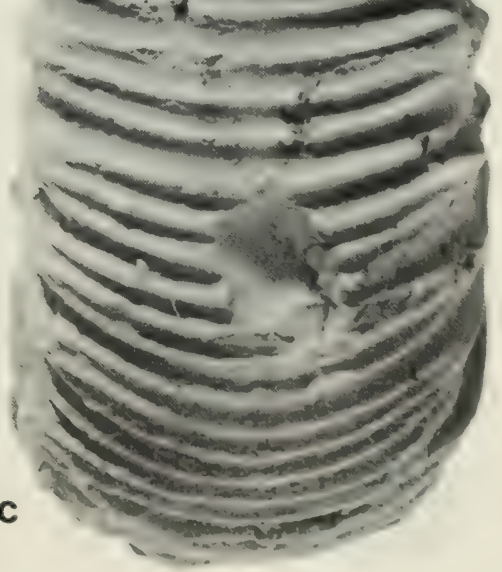
Plate 5, figs. 1-2

1 Subdichotomoceras? aff. S. sparsiplicatum (Waagen)

Changamwe Shale, Beckeri or basal Hybonotum Zone; boundary Kimmeridgian/Tithonian. Almost complete with aperture missing, lateral (a), apertural (b), and ventral (c) views KNMI-MA41. Loc. 8b, New Mto Panga Quarry, Mombasa area.

2 Katroliceras? cf. K. bathyplocus (Waagen) $\widehat{0}$

Changamwe Shale, Beckeri Zone; Upper Kimmeridgian. Microconch, slightly damaged with somewhat crushed body chamber, lateral (a) and apertural (b) views KNMI-MA39. Loc. 8h, New Mto Panga Quarry, Mombasa area.

Scale for all figures equals $1 \mathrm{~cm}$. 


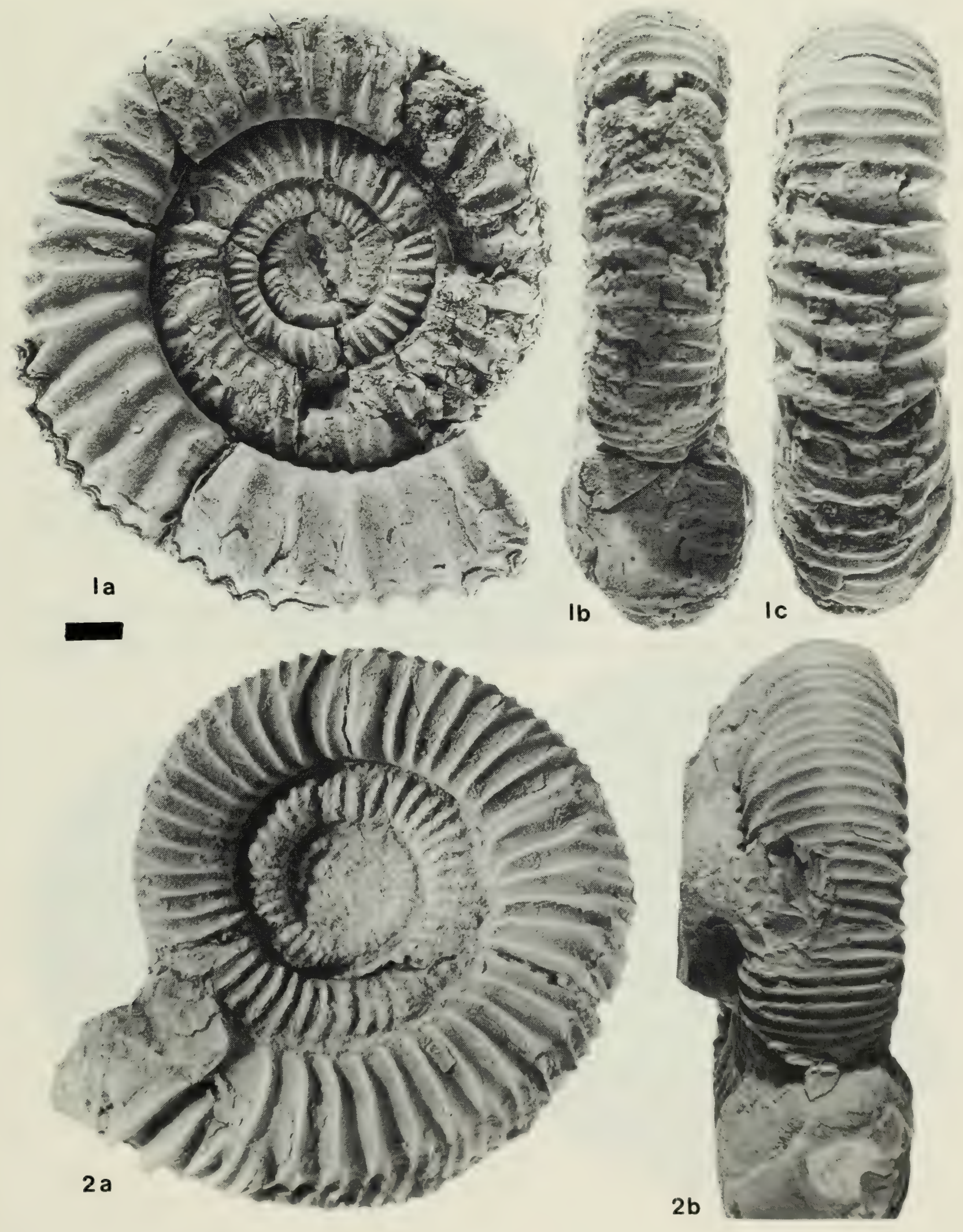


Plate 6, figs. 1-3

1-2 Pachysphinctes beyrichi (Futterer)

Changamwe Shale, Hybonotum Zone; Lower Tithonian. 1. Phragmocone with partial body chamber, lateral view KNMI-MA36. 2. Phragmocone with one-third whorl body chamber well preserved, apertural (a) and lateral (b) views KNMI-MA35. Loc. 8d, New Mto Panga Quarry, Mombasa area.

3 Subdichotomoceras(?) cf. S. sparsiplicatum (Waagen)

Changamwe Shale, Hybonotum Zone; Lower Tithonian. Phragmocone with one-quarter whorl body chamber, lateral view KNMI-MA40. Loc. 8d, New Mto Panga Quarry, Mombasa area.

Scale for all figures equals $1 \mathrm{~cm}$. 


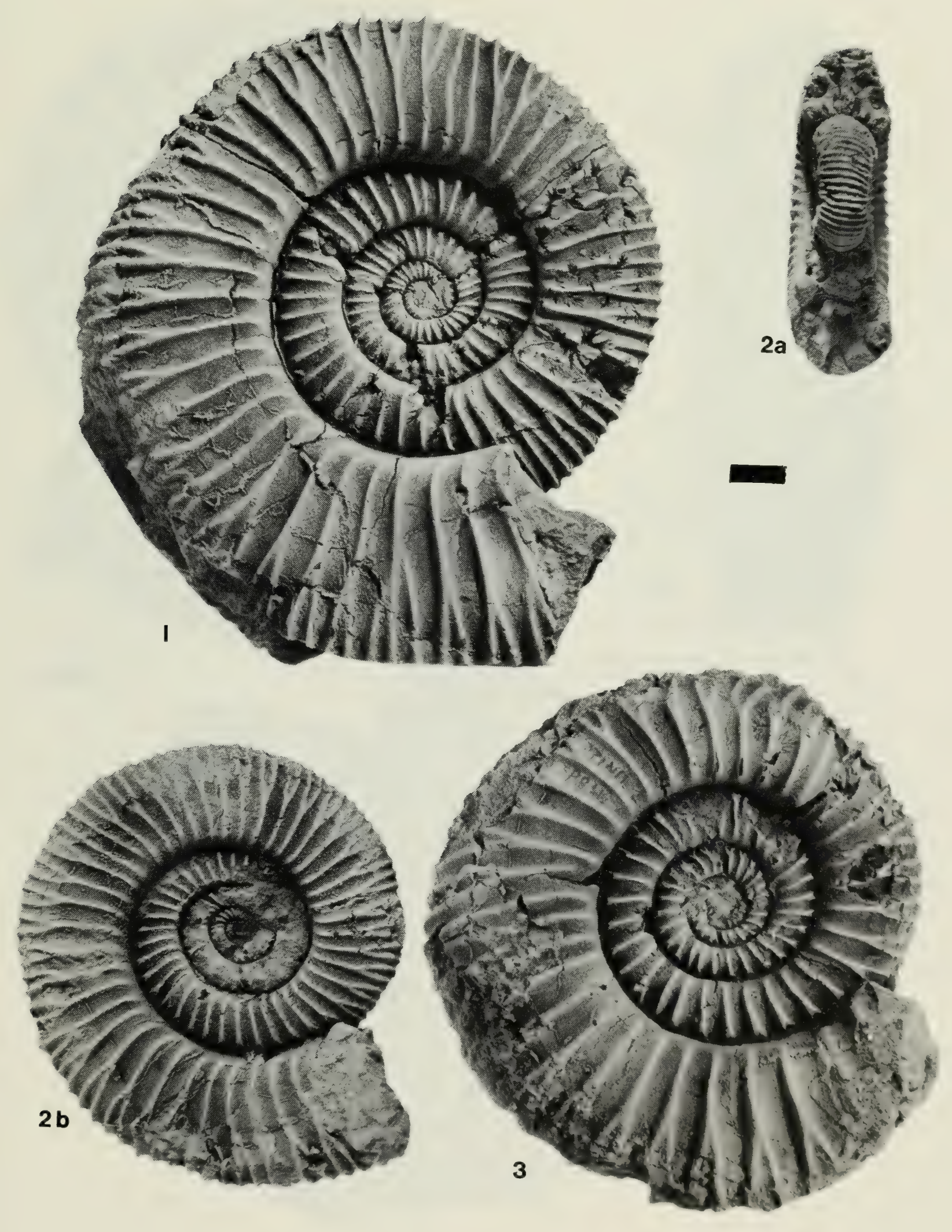


Plate 7, figs. 1-2

1-2 Subdichotomoceras(?) cf. S. sparsiplicatum (Waagen)

Changamwe Shale, Hybonotum Zone; Lower Tithonian. 1. Less than one-third whorl body chamber or entirely septate and partially crushed, lateral (a) and ventral (b) views KNMI-MA7731. 2. Entirely septate and partially crushed, lateral view KNMI-MA7732. Loc. $8 \mathrm{~d}, 1$ to $3 \mathrm{~km}$ north of Freretown, Mombasa area.

Scale for all figures equals $1 \mathrm{~cm}$. 


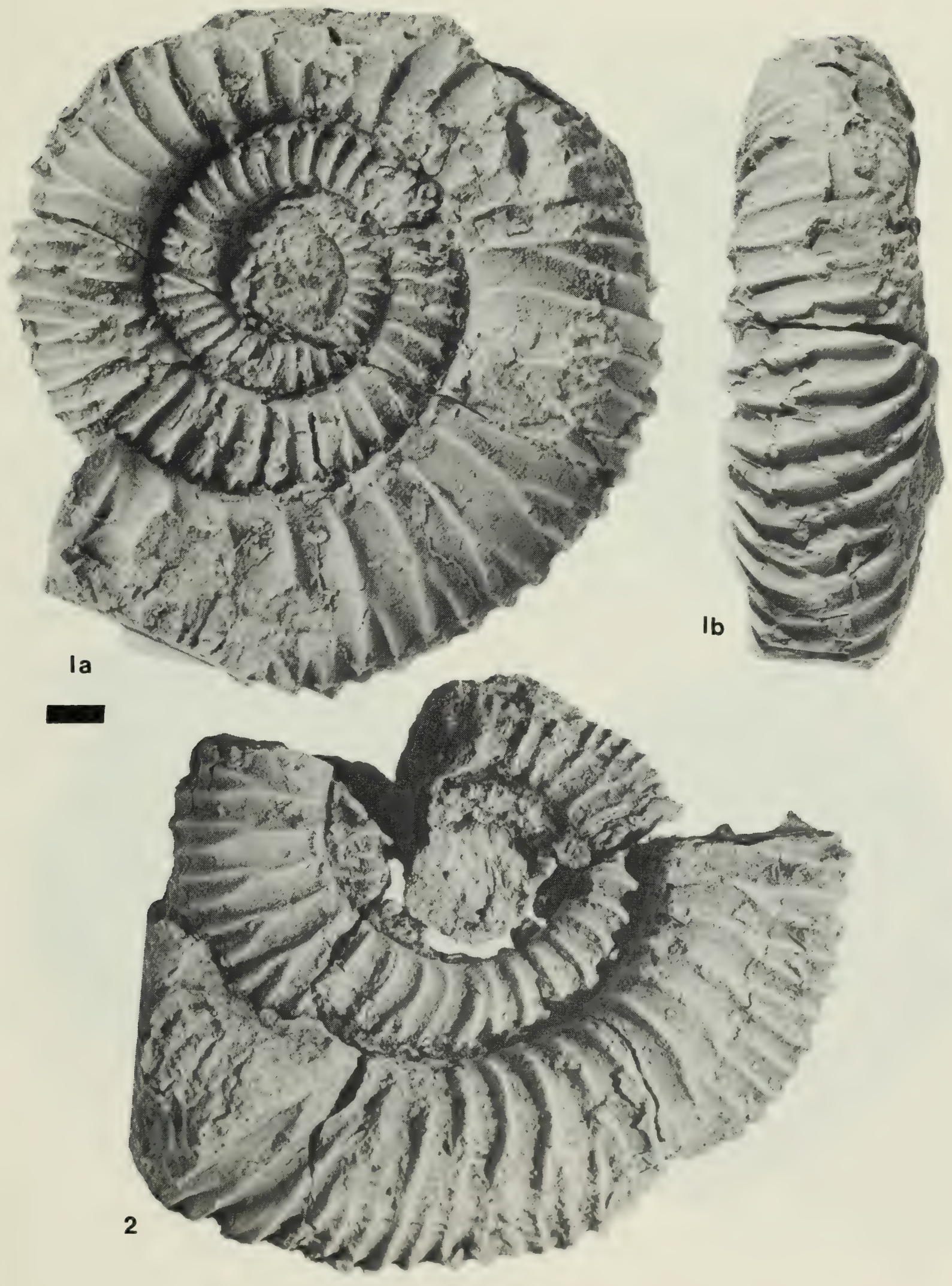


Plate 8 , figs. 1-3

1 Lithococeras? mombassanum (Dacqué)

Changamwe Shale, Hybonotum Zone; Lower Tithonian. Well-preserved juvenile?, lateral (a) and apertural (b) views KNMI-MA43b. Loc. 8d, New Mto Panga Quarry, Mombasa area.

2 Lithacoceras cf. L. fraasi (Dacqué)

Changamwe Shale, Hybonotum Zone; Lower Tithonian. Partly crushed and incomplete phragmocone, lateral view KNMI-MA42. Loc. 8c, New Mto Panga Quarry, Mombasa area.

3 Lithacoceras cf. L. albulum (Quenstedt)

Changamwe Shale, Beckeri Zone; Upper Kimmeridgian. Phragmocone with one-half whorl damaged body chamber without aperture, lateral view KNMI-MA44. Loc. 8b, New Mto Panga Quarry, Mombasa area.

Scale for all figures equals $1 \mathrm{~cm}$. 

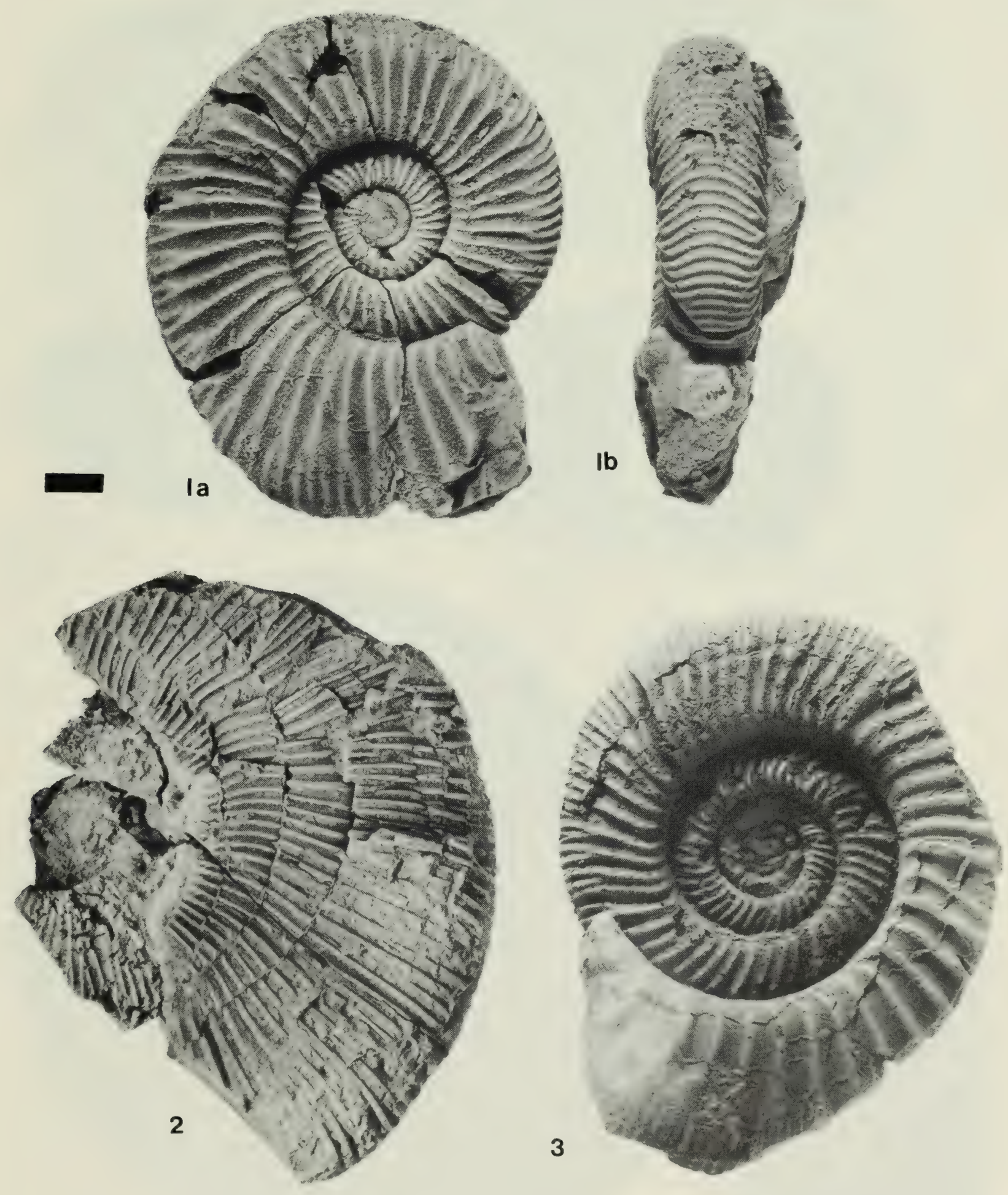


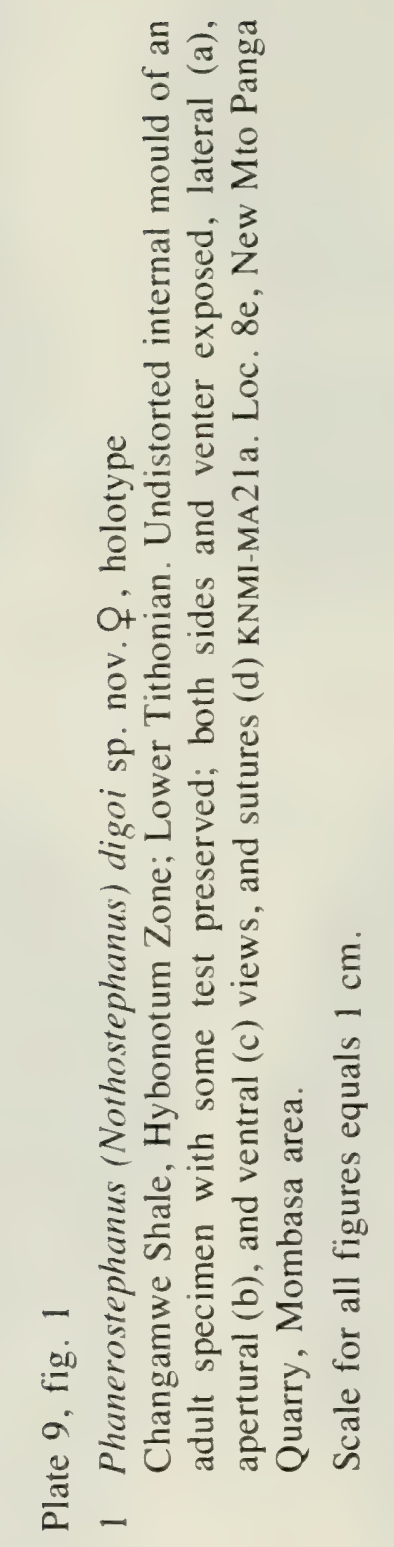




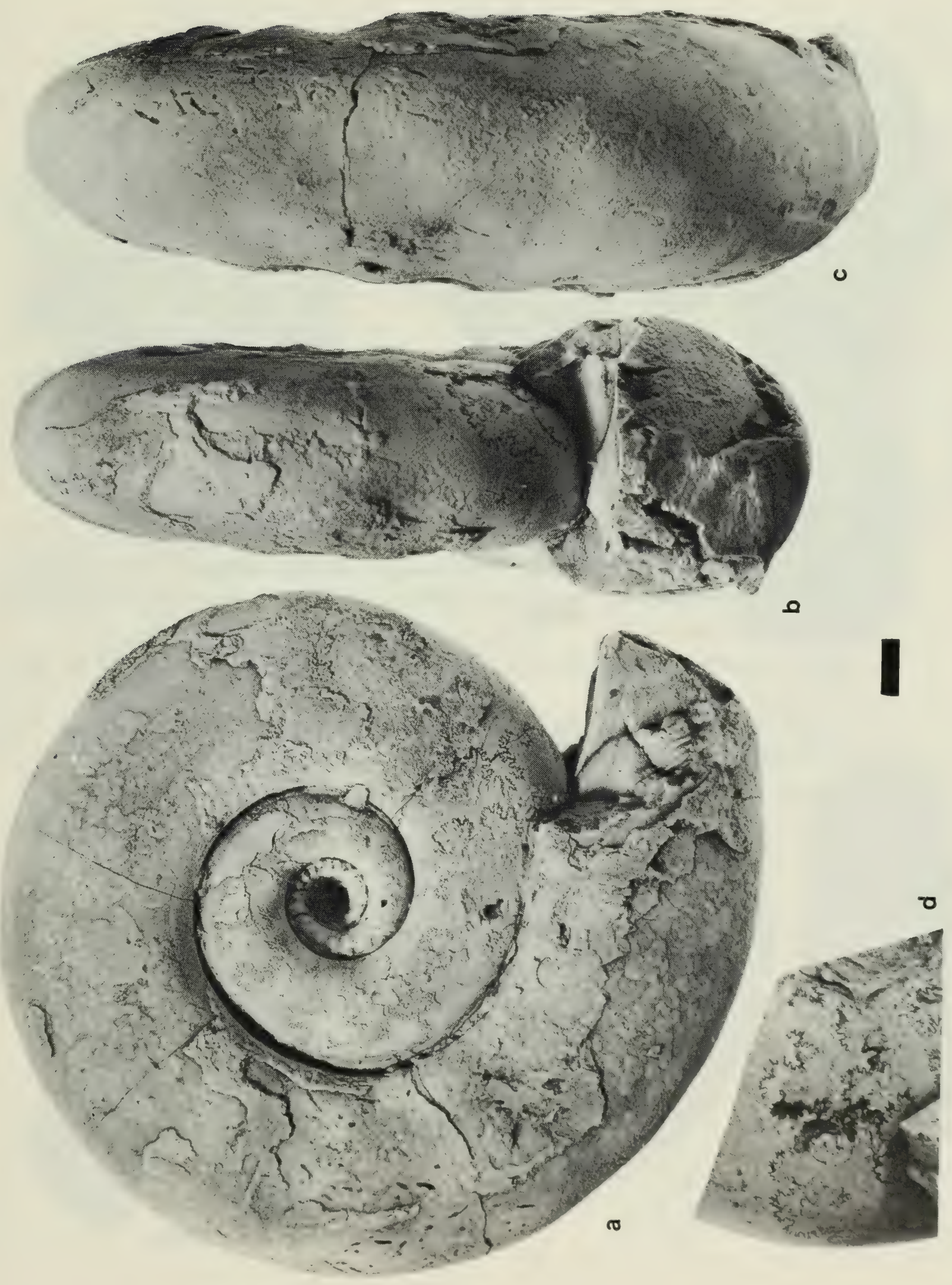


Plate 10, figs. 1-3

Phanerostephanus (Nothostephanus) digoi sp. nov. ㅇ, paratypes

Changamwe Shale, Hybonotum Zone; Lower Tithonian.

1 Adult shell with one-quarter whorl incomplete body chamber; full lateral view (a) and part of outer whorls removed to show ribbed venter of adolescent stage, lateral (b) and ventral (c) views KNMI-MA21b.

2 Isolated inner whorl exposing venter, lateral (a), apertural (b), and ventral (c) views KNMI-MA45.

3 Phragmocone with part of body chamber, inner whorls isolated, lateral (a) and ventral (b) views KNMI-MA46. Loc. 8e, New Mto Panga Quarry, Mombasa area.

Scale for all figures equals $1 \mathrm{~cm}$. 

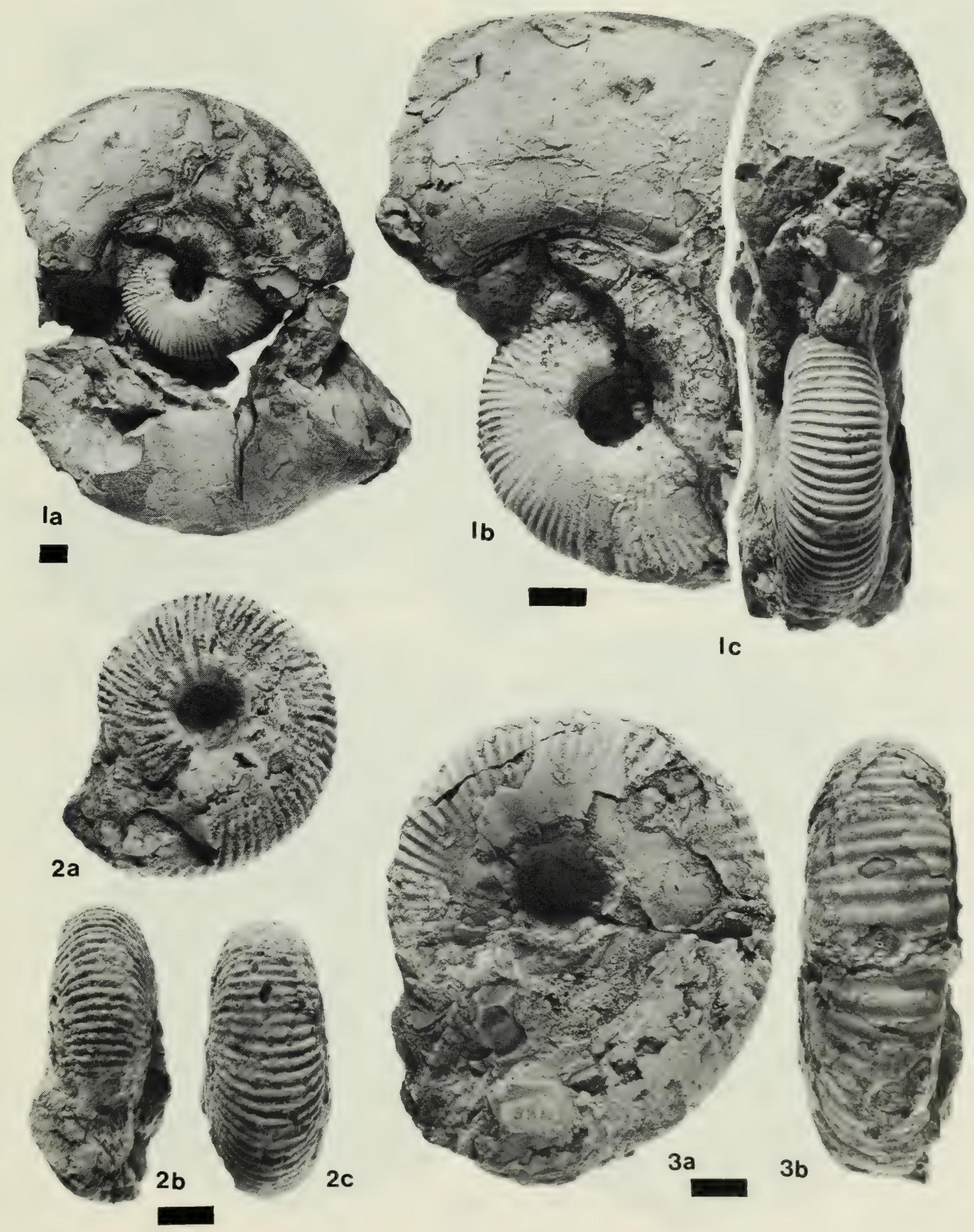
Plate 11, figs. 1-3

1-2 Procraspedites cf. P. africanus (Zwierzicky) 우

Changamwe Shale, Upper Hybonotum Zone; Lower Tithonian. 1. Phragmocone with partially preserved body chamber, lateral (a) and apertural (b) views ROM 34604 . From $600 \mathrm{~m}$ northwest of New Mto Panga Shale Quarry (above bed 8e). 2. Incomplete specimen, lateral view KNMI-MA47. Loc. 8f, New Mto Panga Quarry, Mombasa area.

3 Gravesia loupekinei sp. nov. +

Paratype: Changamwe Shale, Hybonotum Zone; Lower Tithonian. Weathered phragmocone with body chamber, lateral views (a,b) KNMI-MA49. Loc. 8d, New Mto Panga Quarry, Mombasa area.

Scale for all figures equals $1 \mathrm{~cm}$. 

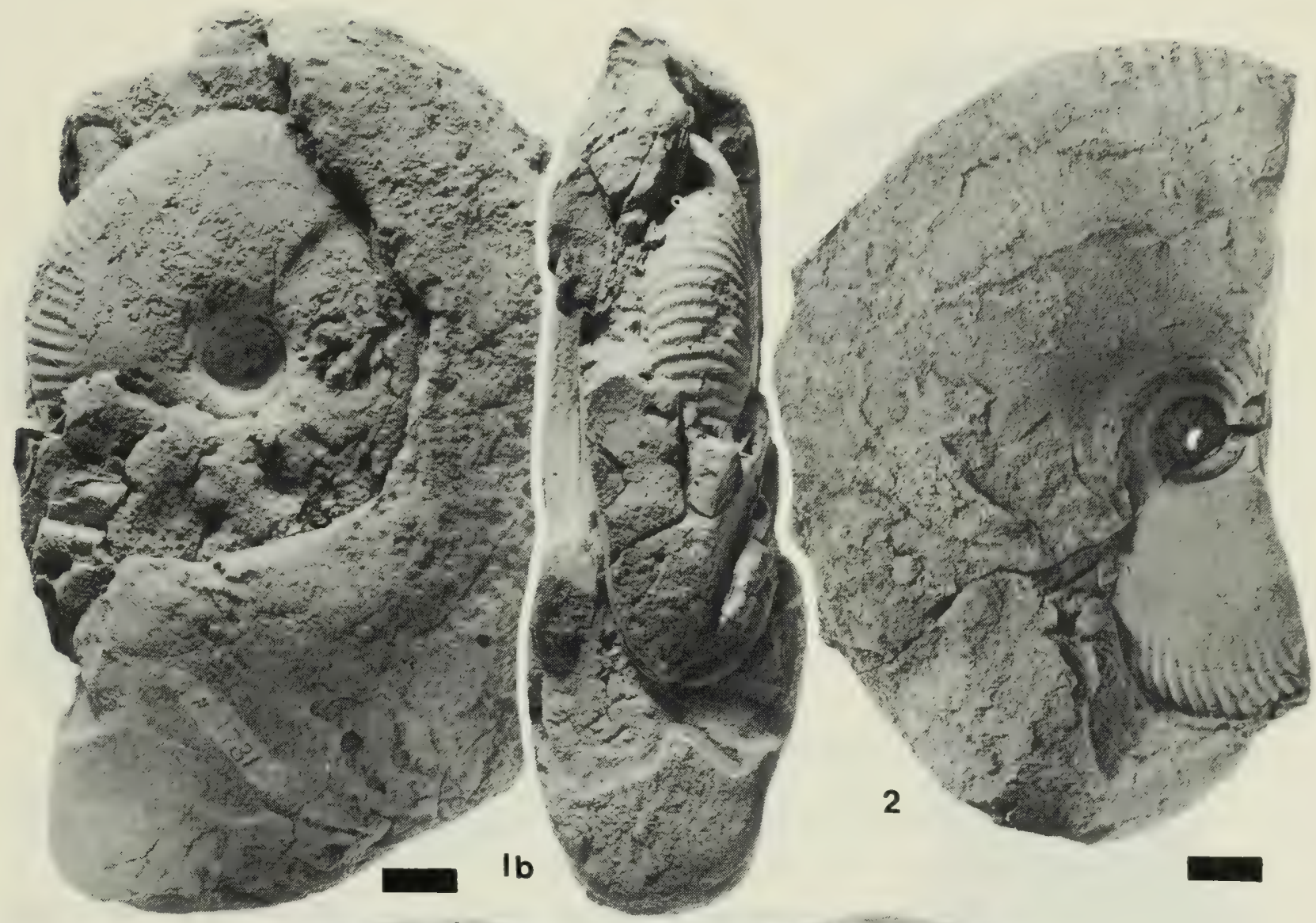

Ia

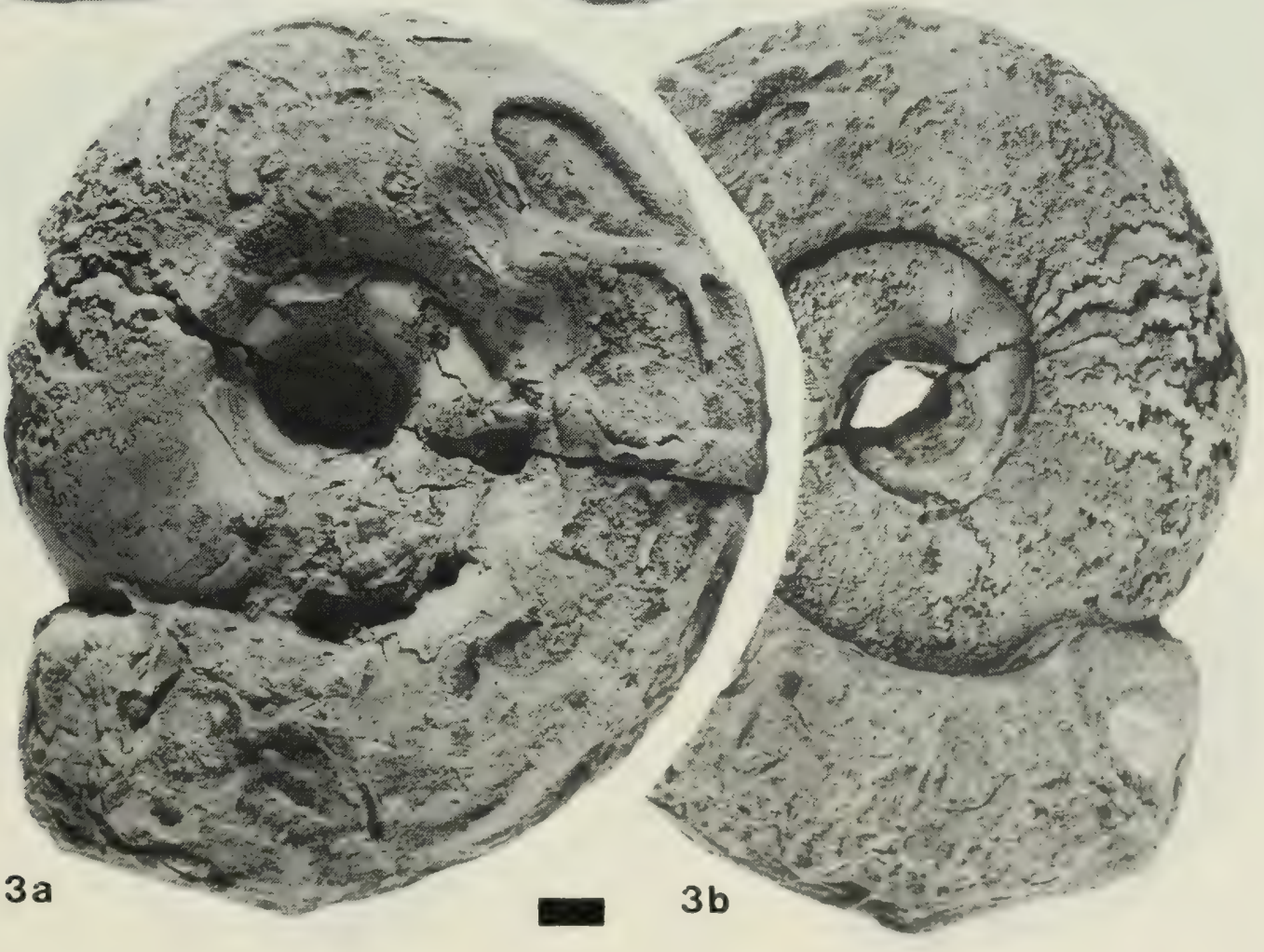


Plate 12, figs. 1-3

Gravesia loupekinei sp. nov. 우

Changamwe Shale, Hybonotum Zone; Lower Tithonian.

1 Holotype: complete slightly distorted internal mould, penultimate whorl damaged, lateral view (a) and penultimate whorl mostly removed to expose whorls, lateral (b) and apertural (c) views KNMI-MA22. Loc. 8e, New Mto Panga Quarry, Mombasa area.

2 Paratype: Incomplete phragmocone, lateral (a), apertural (b), and ventral (c) views ROM 34819. From about $3 \mathrm{~km}$ north-northwest of junction of track to Nguu Tatu and main coast road, Mombasa area.

3 Paratype: Outer whorl removed to expose the penultimate whorl, lateral view KNMI-MA48. Loc. 8d, New Mto Panga Quarry, Mombasa area.

Scale for all figures equals $1 \mathrm{~cm}$. 

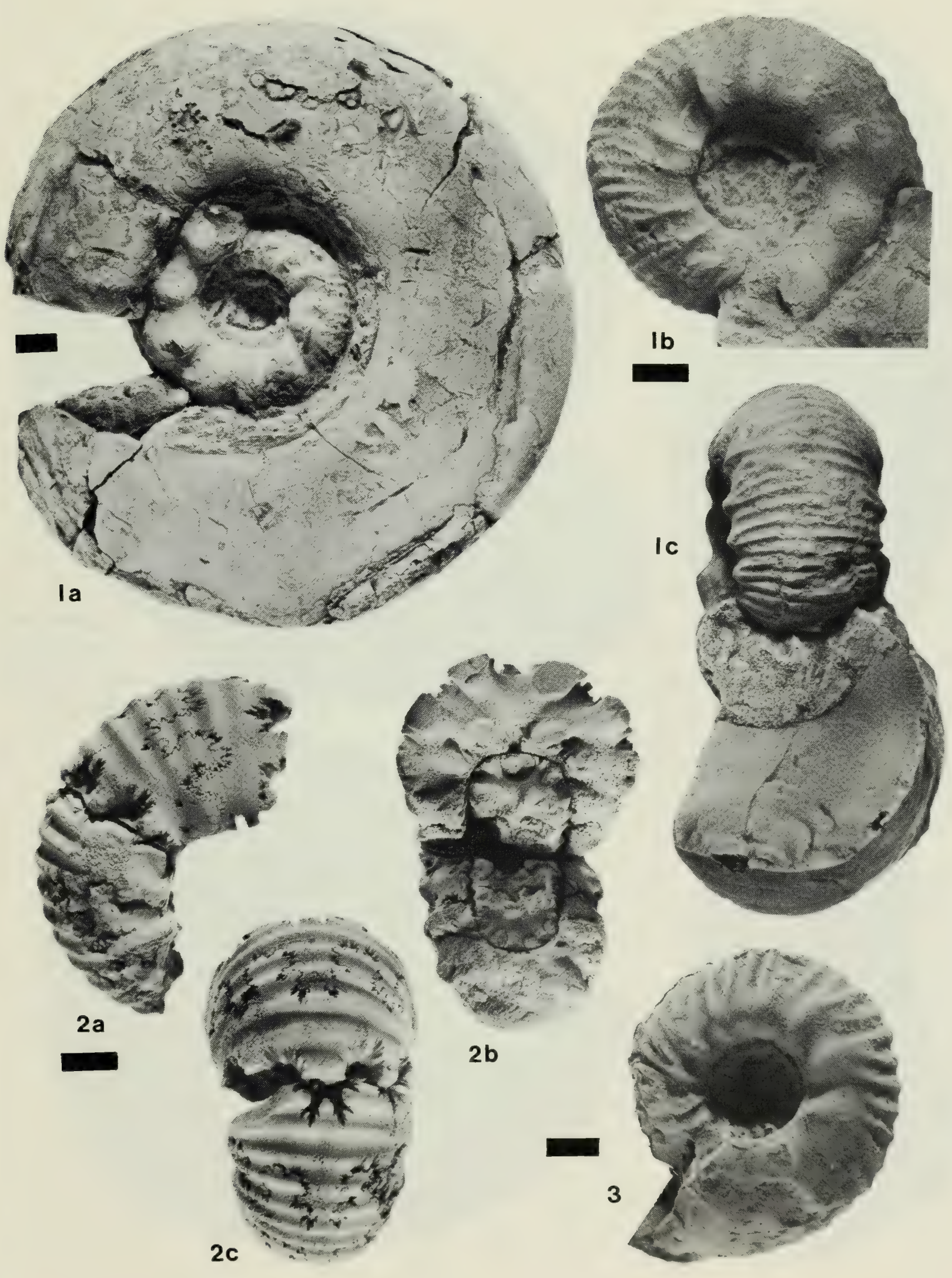

$2 b$ 
Plate 13, fig. 1

1 Gravesia aff. G. loupekinei sp. nov. 우

Changamwe Shale, Hybonotum Zone; Lower Tithonian. Well-preserved phragmocone, slightly damaged internal mould with test remains, complete, lateral (a) and ventral (b) views, and, with part of outer whorl removed to expose inner whorl, lateral (c) and apertural (d) views KNMI-MA50. Loc. 8e, New Mto Panga Quarry, Mombasa area.

Scale for all figures equals $1 \mathrm{~cm}$. 


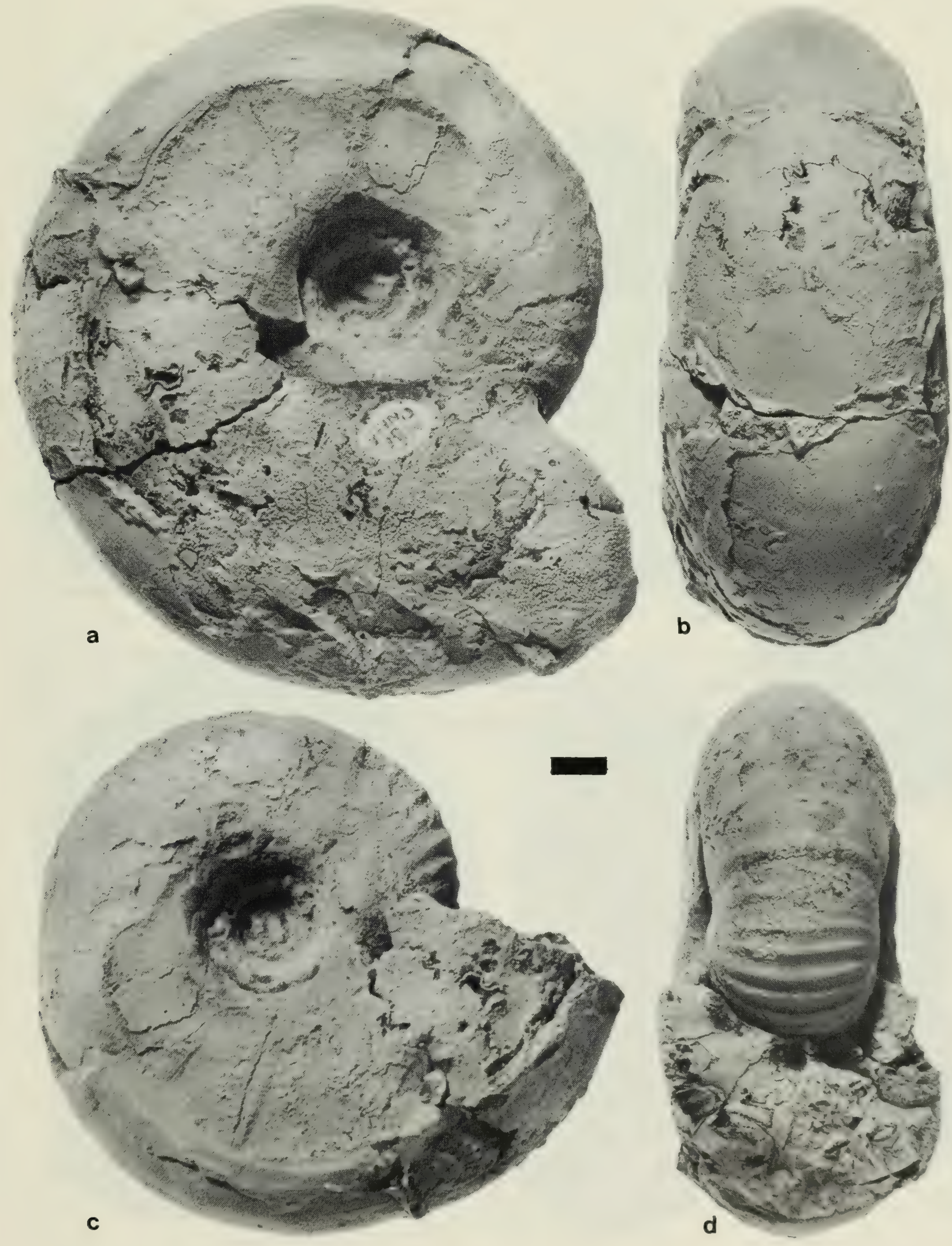


Plate 14, figs. 1-3

Aspidoceras cf. A. acanthicum (Oppel) $+++? \widehat{\jmath}$

Changamwe Shale, Hybonotum Zone; Lower Tithonian.

1 Phragmocone ( $ᄋ$ ) with partial body chamber, lateral (a) and apertural (b) views, sutures (c) ROM 34820 . From 500 to $600 \mathrm{~m}$ east of shore of Port Tudor and $4 \mathrm{~km}$ northeast of Changamwe Station.

2 Phragmocone ( $($ ) with partial body chamber, lateral (a) and apertural (b) views KNMI-MA51. Loc. 8d, New Mto Panga Quarry, Mombasa area.

3 Probable microconch, lateral (a) and apertural (b) views KNMI-MA52. Loc. 8d, New Mto Panga Quarry, Mombasa area.

Scale for all figures equals $1 \mathrm{~cm}$. 

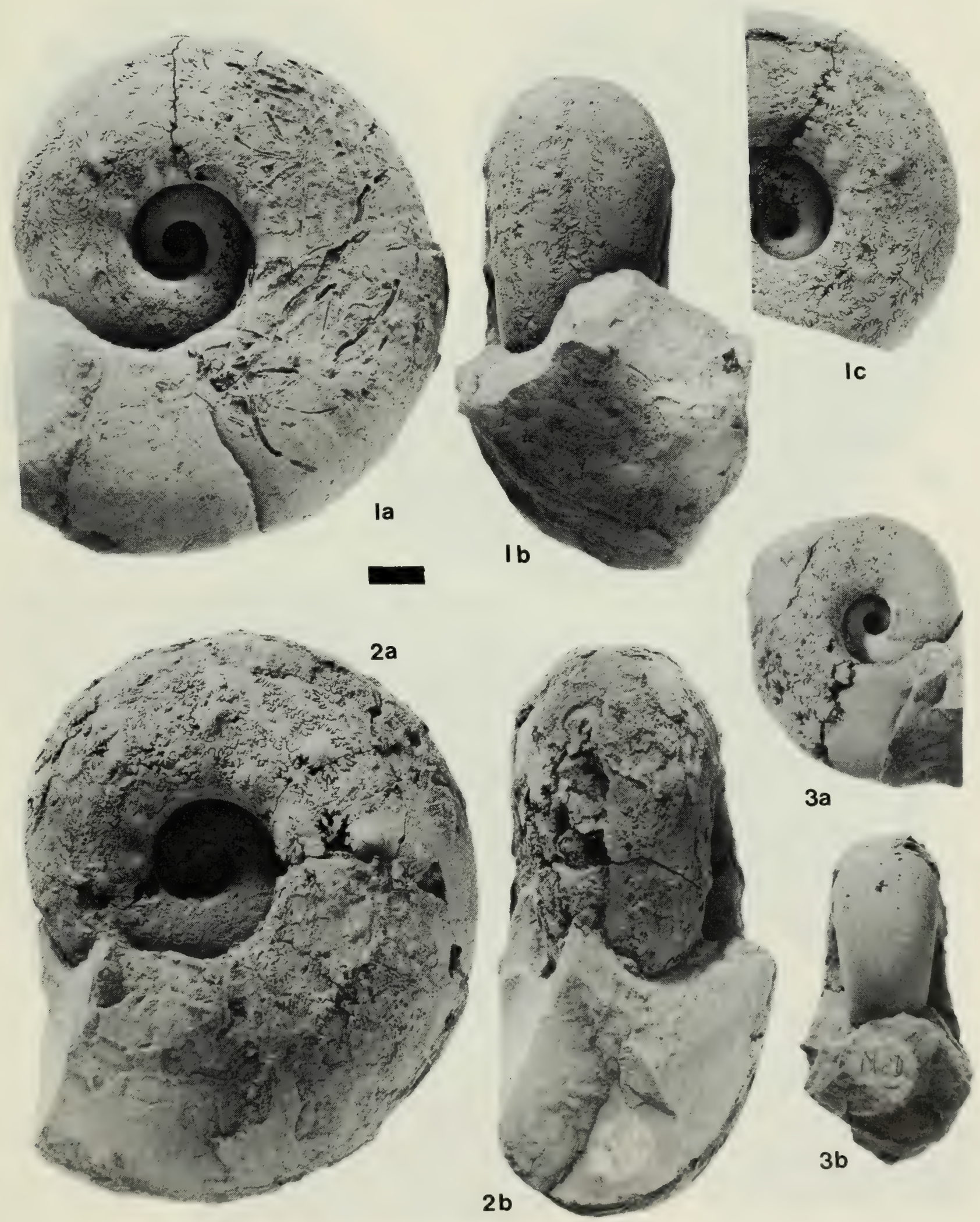
Plate 15, figs. 1-3

1 Aspidoceras aff. A. acanthicum (Oppel) Changamwe Shale, Beckeri Zone; Upper Kimmeridgian. Phragmocone, lateral view KNMI-MA54. Loc. 8k, $1.3 \mathrm{~km}$ north of Freretown, Mombasa area.

2-3 Aspidoceras iphiceroides Waagen +9

Changamwe Shale, Beckeri and Hybonotum Zones; Upper Kimmeridgian and Lower Tithonian. 2. Macroconch with missing inner whorls, lateral view KNMI-MA7733. Loc. 8h, New Mto Panga Quarry, Mombasa area. 3. Complete macroconch, lateral (a) and apertural (b) views KNMI-MA7734. Loc 8d, New Mto Panga Quarry, Mombasa area. Scale for all figures equals $1 \mathrm{~cm}$. 

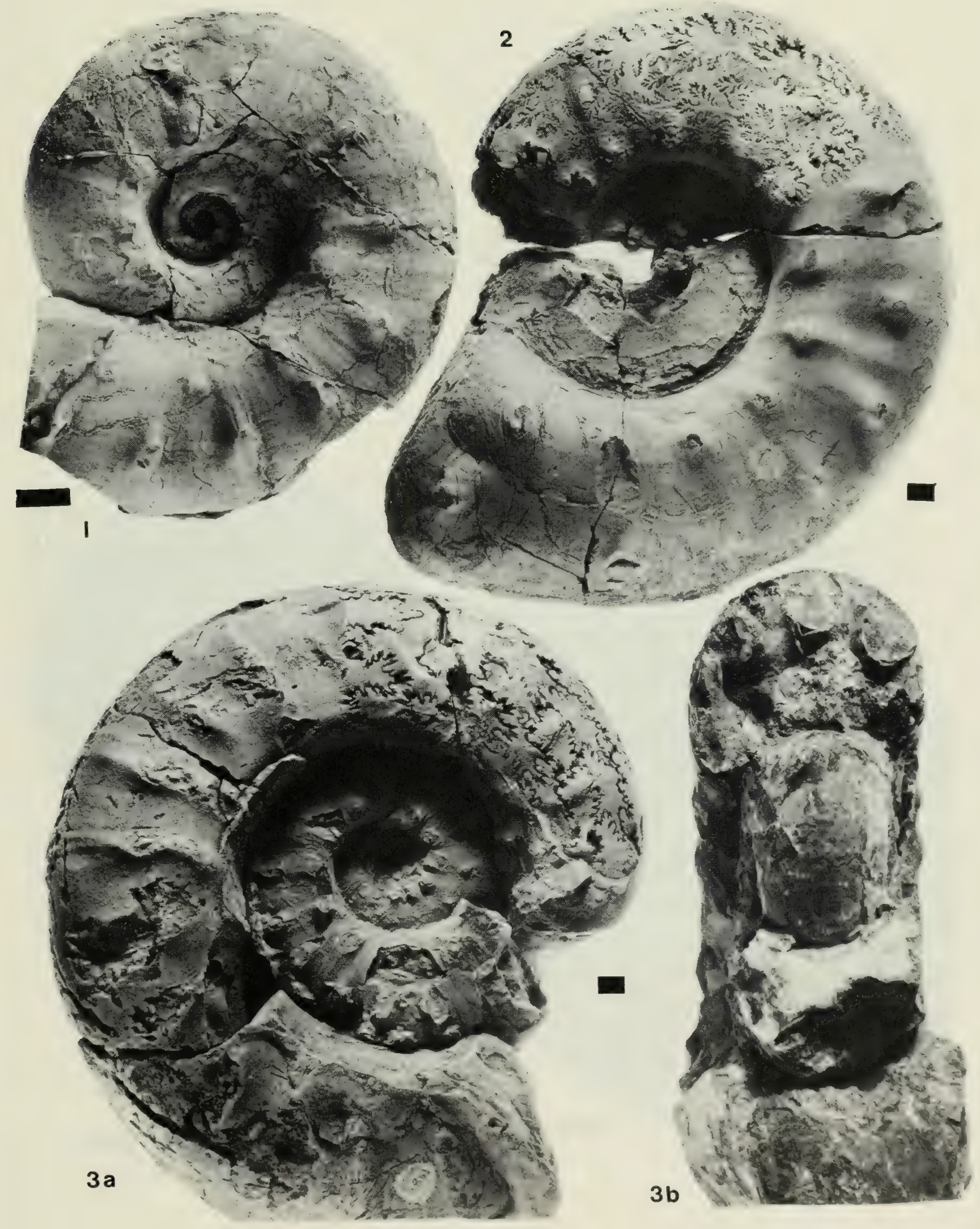
Plate 16, figs. 1-5

1-3 Aspidoceras iphiceroides Waagen $++\hat{\sigma}$

Changamwe Shale, Upper Kimmeridgian and Hybonotum Zone, Lower Tithonian. 1. Complete microconch, lateral (a) and ventral (b) views KNMI-MA56. Loc. 8d, New Mto Panga Quarry, Mombasa area. 2. Spines, lateral view KNMI-MA7735. Loc. 8k, New Mto Panga Quarry, Mombasa area. 3. Microconch with partial body chamber, lateral view KNMI-MA55. Loc. 8a, New Mto Panga Quarry, Mombasa area.

4-5 Aspidoceras cf. iphicerum (Oppel)

Changamwe Shale, Beckeri and basal Hybonotum Zones; Upper Kimmeridgian/Lower Tithonian. 4. Crushed internal mould with part of body chamber, lateral view KNMI-MA57a. Loc. 8a, New Mto Panga Quarry, Mombasa area. 5. Sutures KNMI-MA57c. Loc. 8h, New Mto Panga Quarry, Mombasa area.

Scale for all figures equals $1 \mathrm{~cm}$. 

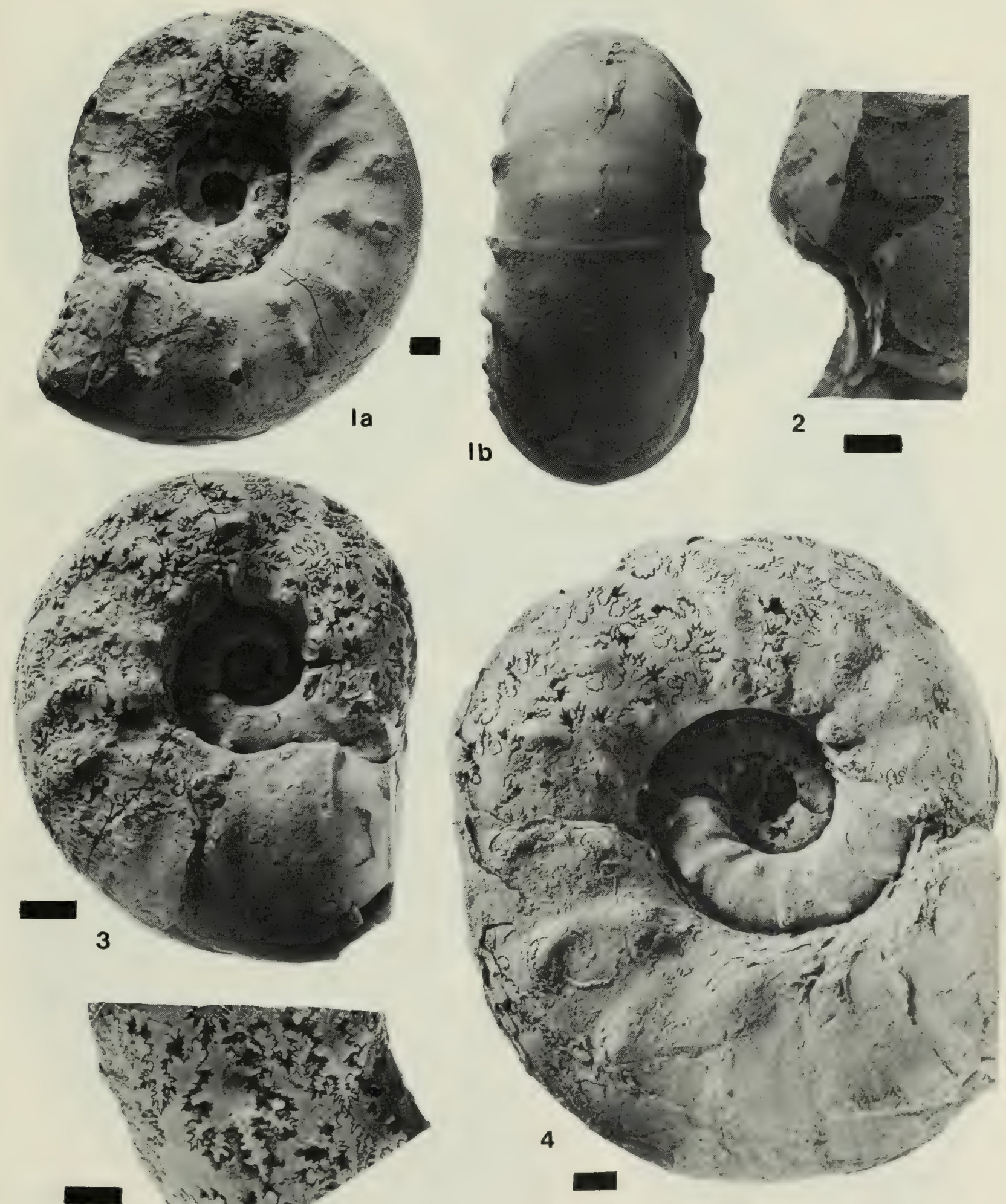

5

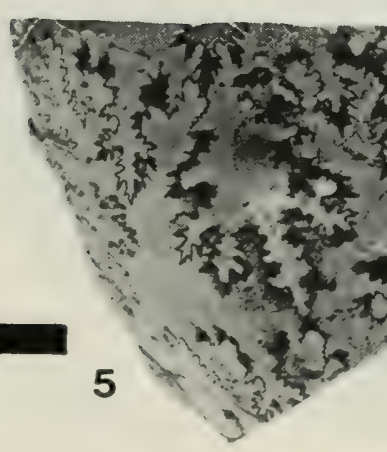


Plate 17, figs. 1-3

1 Aspidoceras cf. A. appenninicum Zittel

Changamwe Shale, Beckeri Zone; Upper Kimmeridgian. Partly crushed large phragmocone without inner whorls, mostly internal mould, lateral views $(a, b)$ KNMI-MA58. Loc. 8h, New Mto Panga Quarry, Mombasa area.

2 Aspidoceras (Physodoceras) cf. A. avellanum Zittel

Changamwe Shale, Hybonotum Zone; Lower Tithonian. Complete specimen with slightly damaged phragmocone, lateral (a) and apertural (b) views KNMI-MA7736. Loc. 8e, New Mto Panga Quarry, Mombasa area.

3 Aspidoceras (Physodoceras) cicumspinosum (Oppel)

Changamwe Shale, Hybonotum Zone; Lower Tithonian. Phragmocone with partially preserved umbilical spines, lateral (a) and apertural (b) views KNMI-MA60. Loc. 8e, New Mto Panga Quarry, Mombasa area.

Scale for all figures equals $1 \mathrm{~cm}$. 


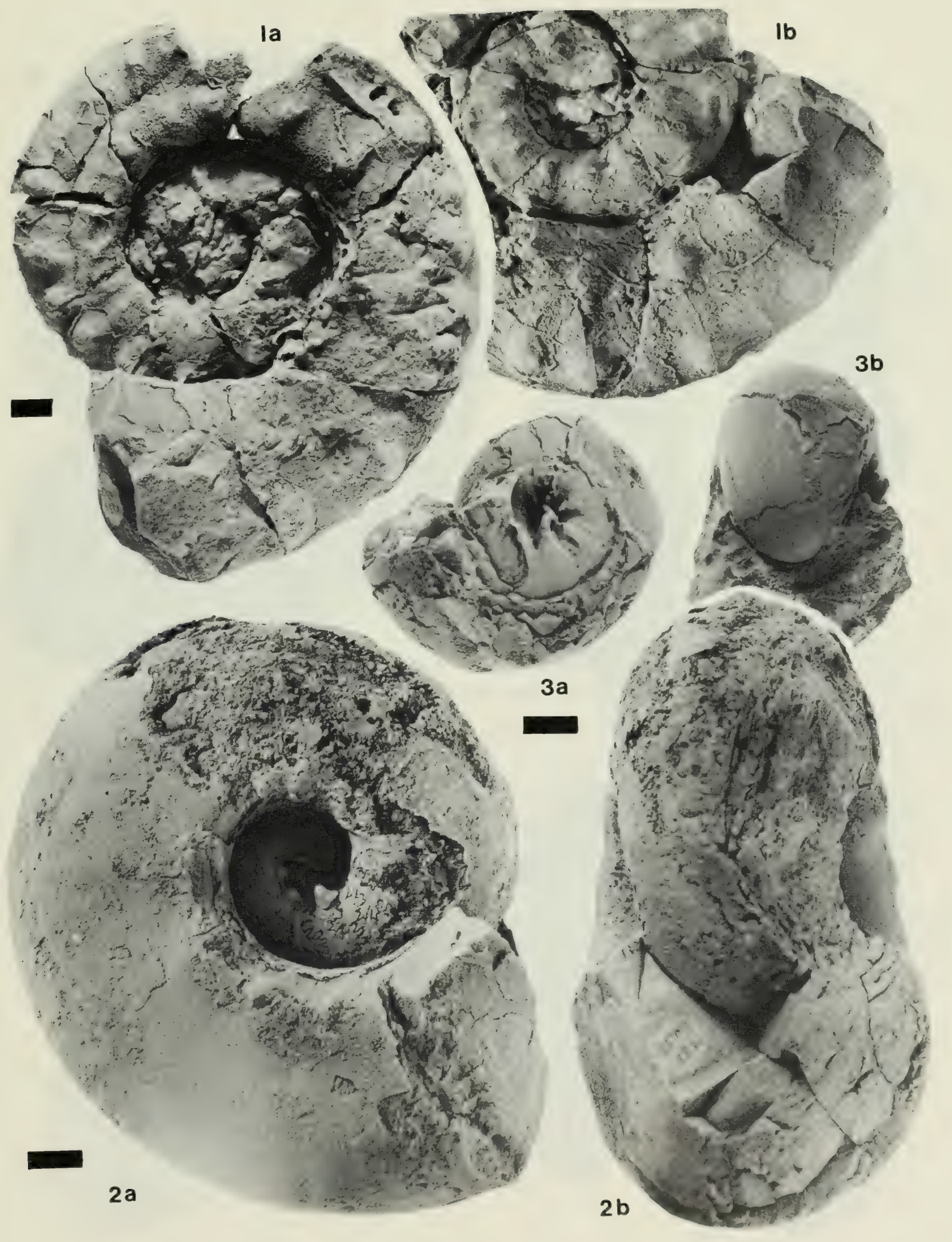


Plate 18, figs, 1-2

1 Hybonoticeras hybonotum (Oppel)

Changamwe Shale, Hybonotum Zone; Lower Tithonian. Phragmocone with part of the body chamber; lateral (a), apertural (b), ventral (c), and oblique (d) views KNMI-MA61a. Loc. 8a, New Mto Panga Quarry, Mombasa area.

2 Hybonoticeras cf. H. hybonotum (Oppel)

Changamwe Shale, Beckeri Zone; Upper Kimmeridgian. Whorl fragment, lateral (a) and ventral (b) views KNMI-MA61c. Loc. 8j, New Mto Panga Quarry, Mombasa area.

Scale for all figures equals $1 \mathrm{~cm}$. 

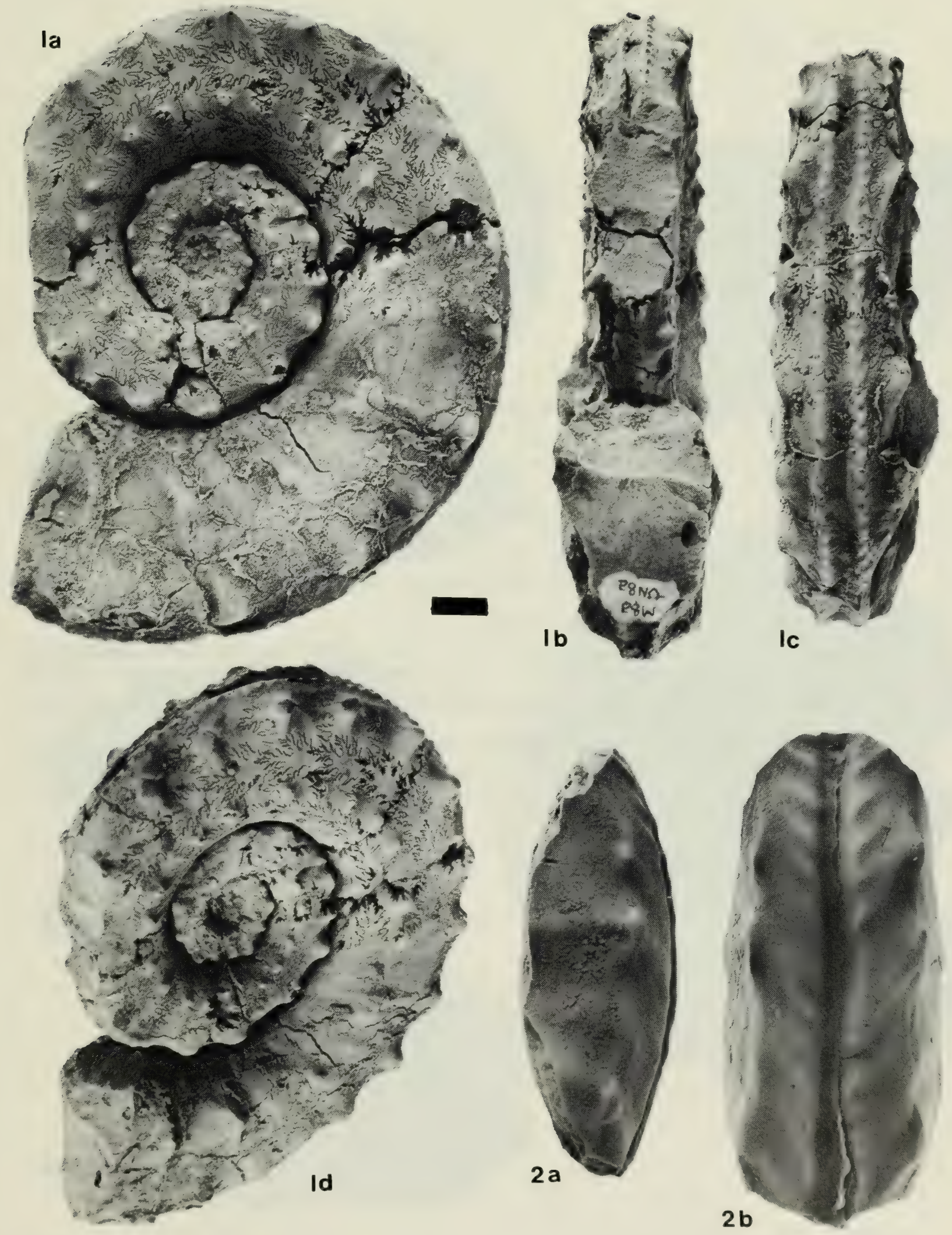
Plate 19 , figs. $1-5$

1 Hybonoticeras pressulum (Neumayr)

Changamwe Shale, Beckeri Zone; Upper Kimmeridgian. Complete specimen, inner whorls obscured, lateral view KNMI-MA63a. Loc. 8h, New Mto Panga Quarry, Mombasa area.

2 Hybonoticeras hybonotum (Oppel)

Changamwe Shale, Hybonotum Zone; Lower Tithonian. Part of the body chamber KNMI-MA61b. Loc. 8c, New Mto Panga Quarry, Mombasa area.

3-4 Hybonoticeras cf. H. ornatum (Spath)

Changamwe Shale, basal Hybonotum Zone; Lower Tithonian. 3. Crushed fragment of body chamber internal mould KNMI-MA62a. 4. Crushed fragment of body chamber internal mould KNMI-MA62b. Both from loc. 8a, New Mto Panga Quarry, Mombasa area.

5 Hybonoticeras cf. $H$. ciliatum Berckhemer and Hölder

Changamwe Shale, Hybonotum Zone; Lower Tithonian. Complete specimen with exposed inner whorls, lateral view KNMI-MA63b. Loc. 8c, New Mto Panga Quarry, Mombasa area.

Scale for all figures equals $1 \mathrm{~cm}$. 

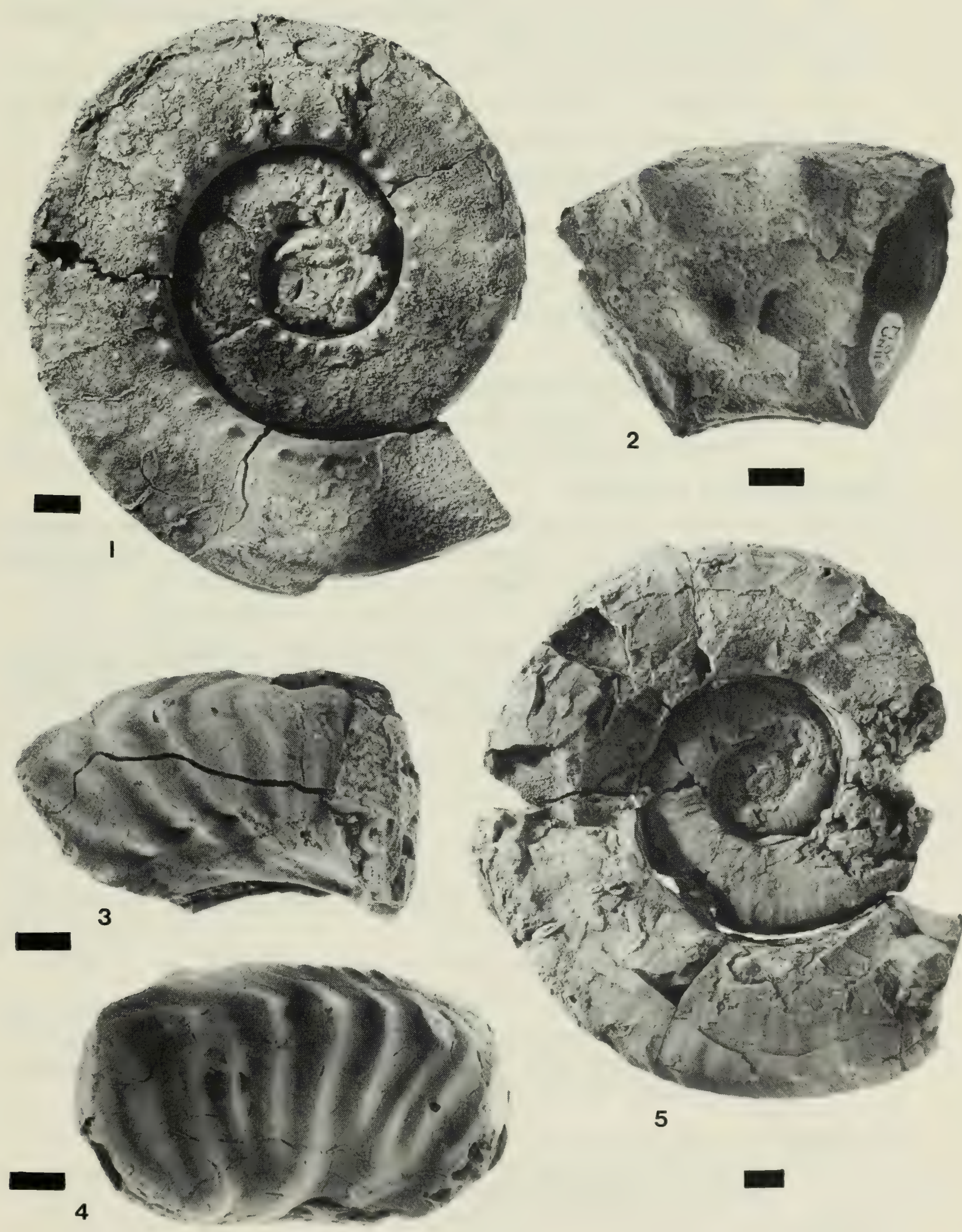

5 


\section{Literature Cited}

AGRAWAL, S. K

1956 Contribution à l'étude stratigraphique et paléontologique du Jurassique du Kutch (Inde). Annales du Centre d'études et de documentation paléontologiques, Paris, 19:1-188.

1957 Kutch Mesozoic: a study of the Jurassic of Kutch with special reference to the Jhura Dome. Journal of the Palaeontological Society of India 2:119-130.

ARKELL, W. J.

1956 Jurassic geology of the world. Edinburgh, Oliver and Boyd. $806 \mathrm{pp}$.

ARKELL, W. J., B. KUMMEL, and C. W. WRIGHT

1957 Mollusca 4, Cephalopoda, Ammonoidea. In Moore, R. C., Treatise on invertebrate paleontology, pt. L. Lawrence, Geological Society of America and University of Kansas Press. $490 \mathrm{pp}$.

BARTHEL, K. W.

1959 Die Cephalopoden des Korallenkalks aus dem Oberen Malm von Laisacker bei Neuberg a. d. Donau. Neues Jahrbuch für Geologie und Paläontologie, Abhandlungen 108(1):47-74.

BARTHEL, K. W. and J. R. GEYSSANT

1973 Additional Tethyan ammonites from the Lower Neuberg formation (Middle Tithonian, Bavaria). Neues Jahrbuch für Geologie und Paläontologie, Monatshefte, 1973, 1:18-36.

BARTHEL, K. W. and G. SCHAIRER

1978 Das Alter einiger Korallenriff- und Stotzenkalke des Oberjura entlang der Donau in Bayern. Mitteilungen der Bayerischen Staatssammlung für Paläontologie und historische Geologie 18:11-27.

BENECKE, E. W

1865 Über Trias und Jura in den Südalpen. Geognostisch-paläontologische Beiträge $1: 1$.

BERCKHEMER, F. and H. HÖLDER

1959 Ammoniten aus dem Oberen Weissen Jura Süddeutschlands. Beihefte zum Geologischen Jahrbuch 35:1-135.

BESAIRIE, $\mathrm{H}$.

1936 Recherches géologiques à Madagascar. Première suite. La géologie du Nord-Ouest. Mémoire de l'Académie Malgache 21(1):1-259.

1972 Géologie de Madagascar. I. Les terrains sédimentaires. Annales géologiques de Madagascar 35:1-463.

BESAIRIE, H. and M. COLLIGNON

1956 Lexique stratigraphique international: Madagascar. Paris, Centre national de la recherche scientifique. $93 \mathrm{pp}$.

BEYRICH, E.

1877 Über jurassische Ammoniten von Mombassa. Monatsberichte der Königlich, preussischen Akademie der Wissenschaften zu Berlin, pp. 96-103.

1878 Über Hildebrandts geologische Sammlungen von Mombassa. Gesammtsitzung der Akademie, 21 November, pp. 767-775. 
BOEHM, G.

1907 Beiträge zur Geologie von Niederländisch Indien. Vol. 1, Die Südküsten der Sula-Inseln Taliabu und Mangoli. Part III, Oxford des Wai Galo. Palaeontographica, Supplement IV, Lieferung 1:59-120, pls. IX-XXXI.

BULLARD, E. C., J. E. EVERETT, and G. SMITH

1965 The fit of the continents around the Atlantic. Philosophical Transactions of the Royal Society of London 1088:41-51.

BURCKHARDT, $\mathrm{C}$.

1906 La faune jurassique de Mazapil, Appendice sur les fossiles du Crétacique inférieur. Instituto de Geología, México, Boletín 23:1-211.

1912 Faunes jurassiques et crétaciques de San Pedro del Gallo, État de Durango, México. Instituto de Geología, México, Boletin 29:1-260.

1930 Étude synthétique sur le Mésozoïque mexicain. Société paléontologique suisse, Mémoire 49-50:1-280.

CALlOMON, J. H. and J. C. W. COPE

1971 The stratigraphy and ammonite succession of the Oxford and Kimmeridge Clay in the Warlingham Borehole. Bulletin of the Geological Survey of Great Britain 36:147-176.

CAREY, S. W

1958 A tectonic approach to continental drift. University of Tasmania, Geology Department, Symposium 5, pp. 177-355.

CASEY, R.

1973 The ammonite succession at the Jurassic-Cretaceous boundary in eastern England. In Casey, R. and Rawson, P. F., eds., The Boreal Lower Cretaceous. Geological Journal, Special Issue 5:193-266.

CASWELL, P. V.

1953 Geology of the Mombasa-Kwale area. Geological Survey of Kenya, Report 24: $1-69$.

1956 Geology of the Kilifi-Mazeras area. Geological Survey of Kenya, Report $34: 1-54$.

CATUlLo, T. A

1847 Prodromo di geognosia paleozoica delle Alpi Venete. Padova, Appendici al Catalogi degli Ammoniti delle Alpi Venete, pp.1-158.

COLLIGNON, $\mathrm{M}$.

1959 Atlas des fossiles caractéristiques de Madagascar, Fasc. 5 (Kimmeridgien). Tananarive, Ministère des mines et de l'énergie, Service géologique, République Malgache, pls. 96-133.

1960 Atlas des fossiles caractéristiques de Madagascar, Fasc. 6 (Tithonique). Tananarive, Ministère des mines et de l'énergie, Service géologique, République Malgache, pls. 134-175.

1962 Atlas des fossiles caractéristiques de Madagascar, Fasc. 8 (Berriasien, Valanginien, Hauterivien, Barrémien). Tananarive, Ministère des mines et de l’énergie, Service gélogique, République Malgache, pls. 176-214.

1964 Échelle chronostratigraphique proposée pour les domaines Indo-AfricanoMalgache (Bathonien moyen à Tithonique). In Maubeuge, P. L., ed., Colloque du Jurassique à Luxembourg, 1962. Congrès géologique international, Commission internationale de stratigraphie. Luxembourg, Publication de l'Institut Grand-Ducal, Section des sciences naturelles, physiques et mathématiques, pp. 927-931. 
CONTINI, D. and P. HANTZPERGUE

1975 Le Kimmeridgien de Haute-Saône. Annales scientifiques de l'Université de Bescançon, Géologie, 3(23):5-37.

COPE, J. C. W.

1978 The ammonite fauna and stratigraphy of the upper part of the Upper Kimmeridge Clay of Dorset. Palaeontology 31:469-533.

COPE, J. C. W. and A. ZEISS

1964 Zur Parallelisierung des englischen Oberkimmeridge mit dem fränkischen Untertithon (Malm $\mathrm{e}_{2}$ ). Geologische Blätter für Nordost-Bayern und angrenzende Gebiete, Erlangen, 14(1):5-14.

DACQUÉ, E

1904 Beiträge zur Geologie des Somalilandes. Mitteilungen des geologischen und paläontologischen Institutes der Universität Wien, Beiträge zur Paläontologie une Geologie, 17:7-159.

1910 Dogger und Malm aus Ostrafrika. Mitteilungen des geologischen und paläontologischen Institutes der Universität Wien, Beiträge zur Paläontologie und Geologie Österreich-Ungarns und des Orients, 23(2):1-62.

1914 Neue Beiträge zur Kenntnis des Jura in Abessynien. Mitteilungen des Geologischen und paläontologischen Institutes der Universität Wien, Beiträge zur Paläontologie und Geologie Österreich-Ungarns und des Orients, 27(1): 117.

DIETRICH, W. O.

1925 Über eine, dem Mittleren Saurier-Mergel am Tendaguru äquivalente, rein marine Kimmeridge-Bildung in Mahokondo, Deutsch-Ostrafrika. Palaeontographica, Suppl. 7, Reihe 2, (1)1-23.

1933 Zur Stratigraphie und Paläontologie der Tendaguruschichten. Palaeontographica, Suppl. 7, Reihe 2, (2):1-86.

DIETZ, R. S. and J. C. HOLDEN

1970 The breakup of Pangaea. In Continents adrift, readings from Scientific American. San Francisco, W. H. Freeman, pp. 102-113.

DONOVAN, D. T., J. H. CALLOMON, and M. K. HOWARTH

1981 Classification of Jurassic Ammonitina. In House, M. R. and J. R. Senior, The Ammonoidea; the evolution, classification, mode of life and geological usefulness of a major fossil group. Systematics Association, Special Volume 18: $101-156$.

DONZE, P. and R. ENAY

1961 Les Céphalopodes du Tithonique inférieur de la Croix-de-Saint-Concors près Chambéry (Savoie). Travaux du Laboratoire de géologie, Lyon, Nouvelle série, 7:1-236.

EAMES, F. E. and W. J. CLARKE

1964 Megafossils from Freretown-Mto Panga Area, Kenya. British Petroleum Company, Palaeontological Note 494.

ENAY, R.

1963 La nomenclature stratigraphique du Jurassique terminal: ses problèmes et sa normalisation. Département d'information géologique, Bureau de recherches géologiques et minières, Paris, Bulletin trimestrice 39:1-9.

1964 L'étage Tithonique. In Maubeuge, P. L., ed., Colloque du Jurassique à Luxembourg, 1962. Congrès géologique international, Commission inter- 
nationale de stratigraphie. Luxembourg, Publication de l'Institut GrandDucal, Section des sciences naturelles, physiques et mathématiques, pp. 355379.

1966 Le genre Gravesia (Ammonitina jurassique) dans le Jura français et les chaînes subalpines. Annales de paléontologie, invertébrés, 52(1):95-105.

1972 Paléobiogéographie des ammonites du Jurassique terminal (Tithonique/Volgien/Portlandien s.1.) et mobilité continentale. Géobios 5:355-407.

1973 Upper Jurassic (Tithonian) ammonites. In Hallam, A., ed., Atlas of palaeobiogeography. Amsterdam, Elsevier, pp. 297-307.

1980 Paléobiogéographie et ammonites jurassiques: "rythmes fauniques" et variations du niveau marine; voies d'échanges, migrations et domaines biogéographiques. Livre jubilaire de la Société géologique de France, Mémoire $10: 261-281$.

ENAY, R. and J. R. GEYSSANT

1975 Faunes tithoniques des chaînes bétiques (Espagne méridionale). Colloque sur la limite jurassique-crétacé, Lyon, Neuchâtel, 1973. Bureau de recherches géologiques et minières, Paris, Mémoire 86:39-55.

ENAY, R., C. MARTIN, O. MONOD, and J. P. THIEULOY

1971 Jurassique supérieur à ammonites (kimméridgien-tithonique) dans l'autochtone du Taurus de Beysehir (Turquie méridionale). Annales Instituti Geologici Publici Hungarici 54(2):387-422.

FRAAS, 0.

1859 Jurassisches Verkommen an der Ostküste von Afrika. Jahreschefte des Vereins für vaterländische Naturkunde in Württemberg 15:356.

FUTTERER, K.

1894 Beiträge zur Kenntniss des Jura in Ost-Afrika. Zeitschrift der Deutschen geologischen Gesellschaft 1(A): 1-49.

GEMMELLARO, G. G.

1872-82 Sopra alcune fauna giuresi e liasiche della Sicilia. Studi Palaeontologici, Palermo 8:1-434.

GREGORY, J. W.

1921 The rift valleys and geology of East Africa. London, Seeley. 479 pp.

1930 A second collection of fossil corals from the Kenya Coastlands made by Miss McKinnon Wood. Monographs of the Geological Department of the Hunterian Museum, Glasgow University, 4:185-209.

HAHN, W.

1963 Die Gattung Gravesia Salfeld (Ammonoidea) im Oberjura Mittel- und Nordwesteuropas. Palaeontographica (Abt. A) 122:90-110.

HALLAM, A.

1969a Tectonism and eustasy in the Jurassic. Earth-Science Reviews 5:45-68.

1969b Faunal realms and facies in the Jurassic. Palaeontology 12:1-18.

1971 Evaluation of bathymetric criteria for the Mediterranean. Instituti Geologici Publici Hungarici, Annales 54(2):63-69.

1977 Atlas of palaeobiogeography. Amsterdam, Elsevier Scientific. 531 pp.

HAUG, E.

1907 Traité de géologie. I. Les phénomènes géologiques. II. Les périodes géologiques. Paris. 2021 pp. 
HAW, D.

1964 Geology of the Freretown area, Mombasa, Kenya. British Petroleum-Shell Petroleum Development Company of Kenya, Unpublished Report DH/15.

HELMSTEADT, $\mathrm{H}$

1969 Eine Ammoniten-Fauna aus den Spiti-Schiefern von Muktinath in Nepal. Zitteliana 1:63-88.

IMLAY, R. W.

1939 Upper Jurassic ammonites from Mexico. Geological Society of America Bulletin 50:1-78.

1965 Jurassic marine faunal differentiation in North America. Journal of Paleontology 39: 1023-1038.

JANENSCH, W. and E. HENNIG

1914 Tabellarische Übersicht der Fundorte wirbelloser Fossilien im Arbeitsgebiet der Tendaguru-Expedition. Archiv für Biontologie 3(4):3-6.

LEANZA, A. F.

1945 Ammonites del Jurásico superior y del Cretáceo inferior de la Sierra Azul, en la parte meridional de la provincia de Mendoza. Anales del Museo de la Plata, Paleontologia Sección A, Paleozoología, 6(1):1-99.

1946 Las Oppelias de Chacay-Melehue en el Neuquén. Revista, Sociedad Geológica, Argentina 1(1):63-72.

LINTON, R. E. and R. G. MACLEAN

1955 Sediments of coastal Kenya. British Petroleum-Shell Petroleum Development Company of Kenya, Unpublished Report.

MAUBEUGE, P. L.

1964 Colloque du Jurassique à Luxembourg, 1962. Congrès géologique international, Commission internationale de stratigraphie. Luxembourg, Publication de l'Institut Grand-Ducal, Section des sciences naturelles, physiques et mathématiques. $948 \mathrm{pp}$.

McKINNON WOOD, M.

1930 The stratigraphy of the Kenya Coastlands. Monographs of the Geological Department of the Hunterian Museum, Glasgow University, 4:218-232.

1938 Some further geological observations on the coastlands of Kenya. Monographs of the Geological Department of the Hunterian Museum, Glasgow University, 5:1-11.

MOUTERDE, $R$.

1971 Les formations mésozoiques de la Thakkhola. In Bordet, P. et al., Recherches géologiques dans l'Himalaya du Nepal, région de la Thakkhola. Paris, Centre national de la recherche scientifique, pp. 123-186.

NEUMAYR, $M$.

1871 Jurastudien IV. Die Vertretung der Oxfordgruppe im östlichen Theile der mediterranen Provinz. Jahrbuch der Kaiserlich-Königlichen geologischen Reichsanstalt, Wien, 21:355-376.

1873 Die Fauna der Schichten mit Aspidoceras acanthicum. Abhandlungen der Kaiserlich-Königlichen geologischen Reichsanstalt, Wien, 5(6): 141-257.

1883 Über klimatische Zonen während der Jura- und Kreidezeit. Königliche Akademie der Wissenschaften, Wien, Denkschrift, Mathematisch-naturkundliche Klasse 47:277-310. 
1885 Die geographische Verbreitung der Juraformation. Königliche Akademie der Wissenschaften, Wien, Denkschrift, Mathematisch-naturkundliche Klasse $50: 57-144$.

NIKITIN, S

1886 Über die Beziehungen zwischen der russischen und der westeuropäischen Juraformation. Neues Jahrbuch für Mineralogie, Geologie und Paläontologie $2: 205-248$

OLORIZ, F. and TAVERA, J. M.

1981 El Jurásico de las zonas externas de las Cordilleras béticas. Vol. 3 Zona subbética 11, el Tithonico. II Coloquio de estratigrafia y paleographía de Jurásico de España, pp. 151-170.

OPPEL, A

1862 Über jurassische Cephalopoden. Geognostisch-Paläontologische Beiträge 3:pl. 40-88.

1863-65 Palaeontologische Mitteilungen aus dem Museum des Koeniglich-Bayerischen Staates. Stuttgart, Ebner \& Seubert. 192 pp.

ORBIGNY, A. D'

1842-51 Paléontologie française, description des mollusques et rayonnés fossiles, terrains jurassiques, Tome premier, Céphalopodes. Paris, Victor Masson. $642 \mathrm{pp}$.

QUENSTEDT, F. A

1858 Der Jura. Tübingen, Laupp. $842 \mathrm{pp}$.

1883-88 Die Ammoniten des Schwäbischen Jura. Stuttgart, E. Schweizerbart'sche Verlagshandlung. $1140 \mathrm{pp}$.

RICCARDI, A. G., G. E. G. WESTERMANN, and R. LEVY

1971 The Lower Cretaceous Ammonitina Olcostephanus, Leopoldia, and Favrella from west-central Argentina. Palaeontographica (Abt. A.) 136:83-121.

SAPUNOV, I. G.

1976 Ammonite stratigraphy of the Upper Jurassic in Bulgaria. I. Rock and ammonite successions. Geologica Balcanica 6(3):17-40.

1977 Ammonite stratigraphy of the Upper Jurassic in Bulgaria. III. Kimmeridgian: substages, zones and subzones. Geologica Balcania 7(1):63-80.

SATO, T.

1975 Marine Jurassic formations and faunas in southeast Asia and New Guinea. Geology and Palaeontology of Southeast Asia 15:151-189.

SEYFERT, C. K. and L. A. SIRKIN

1973 Earth history and plate tectonics; an introduction to historical geology. New York, Harper \& Row. 504 pp.

SMITH, A. G

1971 Alpine deformation and the oceanic areas of the Tethys, Mediterranean, and Atlantic. Geological Society of America Bulletin 82:2039-2070.

SMITH, A. G. and J. C. BRIDEN

1977 Mesozoic and Cenozoic palaeocontinental maps. Cambridge, Cambridge University Press. 11 pp. 52 maps.

SMITH, A.G., J. C. BRIDEN, and G. E. DREWRY

1973 Phanerozoic world maps. In Hughes, N. F., ed., Organisms and continents through time. Special Papers in Palaeontology 12:1-42. 
SMITH, A. G. and A. HALLAM

1970 The fit of the southern continents. Nature 225:139-144.

SOWERBY, J. de C.

1825-29 The mineral conchology of Great Britain. London, printed by B. Meredith. Vols. 5-7.

1840 A notice respecting some fossils collected in Kutch. Transactions of the Geological Society, London, 5:715-719.

SPATH, L. F.

1920 On Jurassic ammonites from East Africa, collected by Prof. J. W. Gregory. Geological Magazine 57:311-320, 351-362.

1925 Ammonites and aptychi. In The Collection of fossils and rocks from Somaliland made by Messrs. Wylie and Smellie. Monographs of the Geological Department of the Hunterian Museum, Glasgow University, 1(7):111-164.

1927-33 Revision of the Jurassic cephalopod fauna of Kachh (Cutch). Parts 1-6. Geological Survey of India, Palaeontologia Indica, Memoirs, New Series, 9(2): 1-945.

1930a The Jurassic ammonite faunas of the neighborhood of Mombasa. Monographs of the Geological Department of the Hunterian Museum, Glasgow University, $4: 13-71$.

1950 A new Tithonian ammonoid fauna from Kurdistan, northern Iraq. Bulletin of the British Museum (Natural History), Geology, 1:95-137.

STEVENS, G. R

1963a The type specimens of Belemnopsis tanganensis (Futterer) 1894 (Cephalopoda, Dibrachiata). Transactions of the Royal Society of New Zealand, Geology, 2:131-135,

1963b Faunal realms in Jurassic and Cretaceous belemnites. Geological Magazine $100: 481-497$.

1965 Faunal realms in Jurassic and Cretaceous belemnites. Geological Magazine 102:175-178.

1967 Upper Jurassic fossils from Ellsworth Land, West Antarctica, and notes on Upper Jurassic biogeography of the South Pacific region. New Zealand Journal of Geology and Geophysics 10:345-393.

1968 The Jurassic system in New Zealand. New Zealand Geological Survey, Report 35:1-26.

1971 Relationship of isotopic temperatures and faunal realms to Jurassic-Cretaceous paleogeography, particularly of the Southwest Pacific. Journal of the Royal Society of New Zealand 1:145-158.

UHLIG, V.

1903 The fauna of the Spiti Shales. Memoirs of the Geological Survey of India, Palaeontologia Indica 15, Himalayan fossils, 4:1-132.

1910 Die Fauna der Spiti-Schiefer des Himalaya, ihr geologisches Alter und ihre Weltstellung. Wien, Denkschriften der Kaiserlich-Königlichen Hof- und Staatsdruckerei. $79 \mathrm{pp}$.

VERMA, H. M. and G. E. G. WESTERMANN

1973 The Tithonian (Jurassic) ammonite fauna and stratigraphy of Sierra Catorce, San Luis Potosi, Mexico. Bulletins of American Paleontology 63(277):103320. 
WAAGEN, $\mathbf{W}$.

1873-75 Jurassic fauna of Kutch; Cephalopoda. Memoirs of the Geological Survey of India, Palaeontologia Indica 9, 1:1-247.

WALTERS, R. and R. E. LINTON

1973 The sedimentary basin of coastal Kenya. In Sedimentary basins of the African coasts. Symposium, Part 2, South and East Coasts. Paris, Association des services géologiques africains, pp. 133-158.

WESTERMANN, G. E. G., ed.

1969 Sexual dimorphism in fossil metazoa and taxonomic implications. International Union of Geological Sciences, Series A(1):1-251.

WESTERMANN, G. E. G.

1975 Bajocian ammonites of Tethyan affinities from the Kambe Limestone Series of Kenya and implications to plate tectonics. Newsletters on Stratigraphy $4: 23-48$.

WESTERMANN, G. E. G. and T. A. GETTY

1970 New Middle Jurassic Ammonitina from New Guinea. Bulletins of American Paleontology 57(256):1-318.

WESTERMANN, G. E. G. and A. C. RICCARDI

1976 Middle Jurassic ammonite distribution and the affinities of the Andean faunas. Congreso Geologico Chileno, Actas, vol. 1, pp. C23-C39.

WESTERMANN, G. E. G., T. SATO and S. K. SKWARKO

1978 Brief report on the Jurassic biostratigraphy of the Sula Islands, Indonesia. Newsletters on Stratigraphy 7:96-101.

WIEDMANN, J.

1980 Paläogeographie und Stratigraphie im Grenzbereich Jura/Kreide Südamerikas. Münstersche Forschungen zur Geologie und Paläontologie $51: 27-61$.

WIMBLETON, W. A. and J. C. W. COPE

1978 The ammonite faunas of the English Portland Beds and the zones of the Portlandian Stage. Journal of the Geological Society of London 135:183-190.

ZEISS, A.

1962 Empfehlungen des Jura-colloquiums (Internationaler Geologen-Kongress) in Luxembourg, am 4. August, 1962. Geologische Blätter für Nordost-Bayern und angrenzende Gebiete, Erlangen, 12(4):221-224.

1964 Zur Stratigraphie des Untertithon der südlichen Frankenalb. Colloque du Jurassique, Luxembourg, 1962, Comptes rendus et mémoires, pp. 619-624.

1965 Gliederung und Grenzen des Oberen Jura in Europa. Carpatho-Balkan Geological Association, 7th Congress, Sofia, Report 2(1):107-113.

1968 Untersuchungen zur Paläontologie der Cephalopoden des Unter-Tithon der südlichen Frankenalb. Bayerische Akademie der Wissenschaften, Abhandlungen, neue Folge, 132:1-190.

1971 Berechtigung und Gliederung der Tithon-Stufe und ihre Stellung im Oberen Jura. Colloque du Jurassique, Luxembourg, 1967. Paris, Bureau de recherches géologiques et minières, Mémoire 75:283-292.

1974 Die Callovien-Ammoniten Äthiopiens und ihre zoogeographische Stellung. Palaeontologische Zeitschrift 48:269-282.

1975 On the type region of the lower Tithonian substage. Bureau de recherches géologiques et minières, Paris, Mémoire 86:370-377. 
1977a Jurassic stratigraphy of Franconia. Stuttgarter Beiträge zur Naturkunde, Serie B (Geologie und Paläontologie), 31:1-32.

1977b Some ammonites of the Klentnice Beds (Upper Tithonian) and remarks on correlation of the uppermost Jurassic. Acta Geologica Polonica 27:369-386.

1979 Problems of correlation of the uppermost Jurassic and suggestions to the Cretaceous boundary. In Uppermost Jurassic and the Cretaceous boundary. Academia Nauka USSR, Siberian Section, Institute of Geology and Geophysics for 1979:14-27 [in Russian].

1983 Zur Frage der Äquivalenz der Stufen Tithon/Berrias/Wolga/Portland in Eurasien und Amerika; ein Beitrag zur Klärung der weltweiten Korrelation der Jura-/Kreide-Grenzschichten im marinen Bereich. Zitteliana, 10:427-438.

ZIEGLER, B

1967 Ammoniten-Ökologie am Beispiel des Oberjura. Geologische Rundschau $56: 439-464$.

1971 Biogeographie der Tethys. Jahreshefte der Gesellschaft für Naturkunde, Württemberg, 126:229-243.

1977 The "White" (Upper) Jurassic in Southern Germany. Stuttgarter Beiträge zur Naturkunde, Serie B (Geologie und Paläontologie), 26:1-79.

ZIEGLER, M. A.

1960 Gravesianfunde aus dem "Unteren Portland" der Gegend von Morteau (Doubs). Eclogae Geologicae Helvetiae 52(2):670-677.

ZITTEL, K. A.

1868 Bemerkungen über Phylloceras tatricum Pusch. sp. und einige andere Phylloceras-Arten. Jahrbuch der Kaiserlich-Königlichen geologischen Reichsanstalt, Wien, 19(2):59-68.

1870 Fauna der aelteren Cephalopoden-fuehrender Tithonbildungen. Palaeontographica 2(1-3): 1-191.

ZWIERZICKY, J.

1914 Die Cephalopodenfauna der Tendaguru-Schichten in Deutsch-Ostafrika. Archiv für Biontologie 3(4):7-97. 

ISBN 0-88854-297-6

ISSN 0384-8159 